\title{
AREA OF INFLUENCE AND ZONE OF CONTRIBUTION TO \\ SUPERFUND-SITE WELLS G AND H, WOBURN, MASSACHUSETTS
}

By Charles F. Myette, Julio C. Olimpio, and David G. Johnson

U.S. GEOLOGICAL SURVEY

Water-Resources Investigations Report 87-4100

Prepared in cooperation with the

U.S. ENVIRONMENTAL PROTECTION AGENCY

Boston, Massachusetts

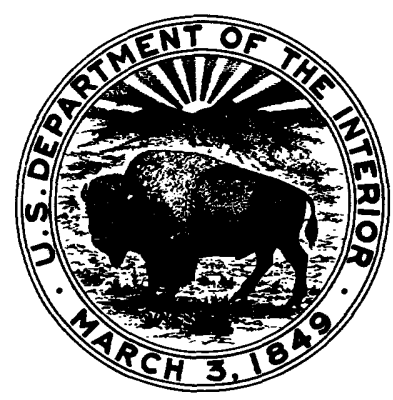

1987 
DEPARTMENT OF THE INTERIOR

DONALD PAUL HODEL, Secretary

\section{U.S. GEOLOGICAL SURVEY}

Dallas L. Peck, Director

For additional information, write to:

U.S. Geological Survey

Water Resources Division

150 Causeway Street, Suite 1309

Boston, MA 02114-1384
Copies of this report can be purchased from:

Books and Open-File Reports Section

U.S. Geological Survey

Box 25425, Federal Center

Denver, CO 80225 


\section{CONTENTS}

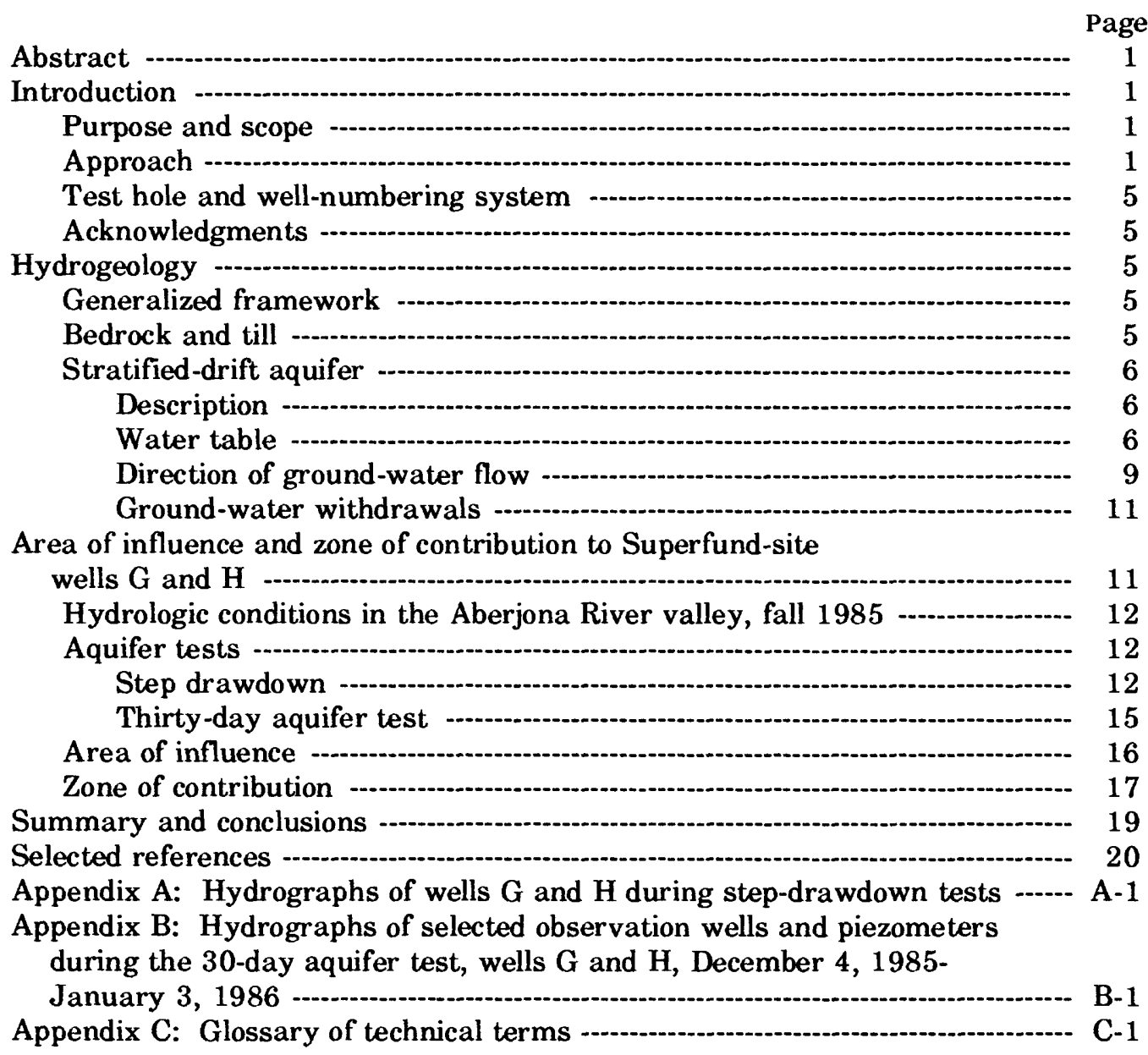

\section{PLATES}

[Plates are in the pocket at back.]

Plate 1. Altitude of the water table in the vicinity of wells $G$ and H, December 4, 1985 .

2. Altitude of the potentiometric surface of wells completed in deep stratified drift and bedrock in the vicinity of wells $G$ and $H$, December 4,1985 .

3. Drawdown of the water-table after 30 days of pumpage from wells $\mathrm{G}$ and $\mathrm{H}$, January 3, 1986.

4. Drawdown of water level in wells completed in deep stratified drift and bedrock after 30 days of pumpage from wells $\mathrm{G}$ and $\mathrm{H}$, January $3,1986$.

5. Altitude of the water table after 30 days of pumpage from wells $\mathrm{G}$ and $\mathrm{H}$, January 3, 1986.

6. Altitude of the potentiometric surface of wells completed in deep stratified drift and bedrock after 30 days of pumpage from wells $G$ and $H$, January 3,1986 . 


\section{ILLUSTRATIONS}

Figure 1. Map showing location of the study area and areal extent of the ground-water-

2. Map showing location of well sites, streamflow-gaging sites, seismic-refraction lines, and geologic section A-A '

3. Geologic sections of the Aberjona River valley

4. Representative geologic section and generalized direction of ground-water flow along section A-A'

5. Graphs showing precipitation, barometric pressure, stream discharge, and ground-water levels near wells $\mathrm{G}$ and $\mathrm{H}$, from November 1, 1985, to January 31,1986

6. Map showing the subbasin drainage area of the Aberjona River comprising the zone of contribution to wells $\mathrm{G}$ and $\mathrm{H}$

\section{TABLE}

Table

1. Summary of miscellaneous discharge measurements in the vicinity of 


\section{CONVERSION FACTORS AND ABBREVIATIONS}

For the convenience of readers who may prefer to use metric (International System) units rather than the inch-pound units used in this report, values may be converted by using the following factors.

Multiply inch-pound unit

By To obtain metric unit

\section{$\underline{\text { Length }}$}

foot $(\mathrm{ft})$

mile (mi)

square mile $\left(\mathrm{mi}^{2}\right)$

cubic foot $\left(\mathrm{ft}^{3}\right)$

foot per second $(\mathrm{ft} / \mathrm{s})$

cubic foot per day $\left(\mathrm{ft}^{3} / \mathrm{d}\right)$

gallon per minute (gal/min)

gallon per minute per foot

$[(\mathrm{gal} / \mathrm{min}) / \mathrm{ft}]$

cubic foot per second per

square mile $\left[\left(\mathrm{ft}^{3} / \mathrm{s}\right) / \mathrm{mi}^{2}\right]$

foot per day $(f \mathrm{t} / \mathrm{d})$
0.3048
1.609
meter (m)
kilometer $(\mathbf{k m})$

$\underline{\text { Area }}$

2.59

square kilometer $\left(\mathbf{k m}^{2}\right)$

$\underline{\text { Volume }}$

$\begin{array}{ll}28.32 & \text { cubic decimeter }\left(\mathrm{dm}^{3}\right) \\ 0.02832 & \text { cubic meter }\left(\mathrm{m}^{3}\right)\end{array}$

Flow

$\begin{array}{cl}3.048 & \text { decimeter per second }(\mathrm{dm} / \mathrm{s}) \\ 28.32 & \text { cubic decimeter per day }\left(\mathrm{dm}^{3} / \mathrm{d}\right) \\ 0.02832 & \text { cubic meter per day }\left(\mathrm{m}^{3} / \mathrm{d}\right) \\ 3.785 & \text { liter per minute }(\mathrm{L} / \mathrm{min}) \\ 3.785 & \begin{array}{c}\text { cubic decimeter per minute } \\ \left(\mathrm{dm}^{3} / \mathrm{min}\right)\end{array} \\ & \begin{array}{c}\text { liter per second per } \\ \text { meter }[(\mathrm{L} / \mathrm{s}) / \mathrm{m}]\end{array} \\ 0.2070 & \begin{array}{c}\text { cubic meter per second per } \\ \text { square kilometer }\left[\left(\mathrm{m}^{3} / \mathrm{s}\right) / \mathrm{km}^{2}\right]\end{array} \\ 0.01093 & \text { square }\end{array}$

Hydraulic conductivity
3.048
decimeter per day $(\mathrm{dm} / \mathrm{d})$
0.3048
meter per day $(\mathrm{m} / \mathrm{d})$

$\underline{\text { Transmissivity }}$

foot squared per day $\left(\mathrm{ft}^{2} / \mathrm{d}\right)$

9.290

0.0929

NGVD of 1929 (National Geodetic Vertical Datum of 1929): A geodetic datum derived from a general adjustment of the first-order level nets of both the United States and Canada. 


\title{
Area of Influence and Zone of Contribution
}

\section{to Superfund-Site Wells G and H,}

\author{
Woburn, Massachusetts
}

\author{
By Charles F. Myette, Julio C. Olimpio, and David G. Johnson
}

\begin{abstract}
Ground-water contamination by chlorinated volatile organic compounds detected by the Massachusetts Department of Environmental Quality Engineering in 1979 forced the closing of wells $G$ and $H$--public-supply wells in the City of Woburn, Massachusetts. The U.S. Environmental Protection Agency has ranked the wells $G$ and $H$ site on the National Priorities List as a CERCLA (Superfund) site and currently is conducting a feasibility study to determine a remedial-action cleanup plan for the site. A 30-day aquifer test was conducted to determine the hydraulic properties of the stratified-drift aquifer in the vicinity of the wells, and to determine the area of influence and zone of contribution to wells $G$ and $H$ under pumping conditions. The estimated transmissivity of the aquifer in the vicinity of well $G$ is 29,700 feet squared per day, with a storage coefficient of 0.20. The average horizontal hydraulic canductivity in the vicinity of the well ranges from 125 to 350 feet per day. The estimated transmissivity of the aquifer at well $H$ is 17,600 feet squared per day, with a storage coefficient of 0.16 . The average horizontal hydraulic conductivity ranges from 130 to 215 feet per day.

The area of influence after 30 days of pumping well $G$ at 700 gallons per minute and well $H$ at 400 gallons per minute is oblong in shape, approximately
\end{abstract}

3,000 feet long and 1,700 feet wide, as measured at the midpoint between wells $G$ and $H$, and comprises an area in which drawdown exceeds 1 foot. The area extends from approximately 1,100 feet north of well $H$ to 1,200 feet south of well $G$. The area of influence of wells $G$ and $H$ described in this report is considered to be a "snapshot" representative of the hydrologic and pumping conditions of the 30-day aquifer test.

Wells $G$ and $H$ obtain water from an area of aquifer, or zone of contribution, that may be divided into two parts. Most of the water pumped by the wells is obtained directly from that part of the aquifer immediately surrounding both wells and from induced infiltration of surface water from the overlying river and wetland. The remaining part of the zone of contribution is that area of the Aberjona River drainage basin upgradient and outside of the area of influence of wells $G$ and $H$. A small amount of the surface water in the river entering the northern end of the study area, which is derived from groundwater discharge and surface-water runoff in the upgradient drainage area, is induced from the river to the wells under pumping conditions. The position of the downgradient limit of the zone of contribution cannot be defined precisely and is not permanently fixed. The size of the area south of wells $G$ and $H$ that contributes water to the wells is variable, dependent on pumping rates and hydrologic conditions. 


\section{INTRODUCTION}

In May 1979, 1,1,1-trichloroethane, 1,2-transdichlorethylene, tetrachloroethylene, chloroform, trichlorotrifluoroethane, and trichloroethene were detected at concentrations ranging from 1 to 400 parts per billion by the MDEQE (Massachusetts Department of Environmental Quality Engineering) in the Woburn public-supply wells $\mathrm{G}$ and $\mathrm{H}$ (fig. 1). The wells were shut down and the USEPA (U.S. Environmental Protection Agency) Region I directed their contractors, E \& E (Ecology and Environment Inc. ${ }^{1}$, to conduct a hydrogeologic investigation and ground-water-quality evaluation of a $10-\mathrm{mi}^{2}$ section of eastern and northern Woburn. The work identified contamination of ground water in both sand and gravel and bedrock in an area of east Woburn with chlorinated volatile organic compounds similar to those found in wells $\mathrm{G}$ and $\mathrm{H}$. The well site was designated as a "Superfund" site in December 1982; as a result of investigations by USEPA and MDEQE, three orders (under Section 3013 of the Resource Conservation and Recovery Act) were issued to W. R. Grace and Co., Inc., Interstate Uniform Services Corp. (now Unifirst Corp.), and Beatrice Foods, Inc., requiring submission of plans for groundwater-quality monitoring pertaining to possible contamination either on or emanating from their properties. The USEPA directed NUS Corp. to conduct an RI (Remedial Investigation) of the wells $\mathrm{G}$ and $\mathrm{H}$ site to determine the nature and extent of ground-water contamination in the area. The RI will support an FS (Feasibility Study) that will examine recommended remedial-action alternatives for the site.

One of the most important data needs identified by the USEPA for the FS was the determination of the area of influence and zone of contribution of water to wells $\mathrm{G}$ and $\mathrm{H}$ under pumping conditions. In March 1985, USEPA Region I requested technical assistance from the U.S. Geological Survey in making this determination.

\section{Purpose and Scope}

This report presents the results of a 10-month study that was authorized under the Interagency Agreement between the U.S. Geological Survey

Use of firm names in this report is for identification purposes only and does not constitute endorsement by the U.S. Geological Survey. and the USEPA to provide the USEPA with the necessary hydrologic data and tools to determine the area of influence and zone of contribution to wells $G$ and $H$ under pumping conditions. The area of influence of wells $G$ and $H$ is the area of the Aberjona River valley in which water levels in the sand and gravel aquifer are affected by pumping. The zone of contribution of wells $G$ and $\mathrm{H}$ is that area of the aquifer that provides ground water to the wells under pumping conditions. The study included design and supervision of the construction of new observation wells, technical guidance and supervision of a 30-day aquifer test of wells $G$ and $H$, and the preparation of a calibrated, three-dimensional ground-water-flow model of the stratified drift of the Aberjona River valley in the vicinity of the wells. This report describes the results of the field study up to the end of the 30-day aquifer test. This report will be followed by a second report describing the concept, design, and operation of the ground-water-flow model.

The study area covers approximately $1.5 \mathrm{mi}^{2}$ and is composed of the stratified-drift aquifer beneath the lowlands of the Aberjona River, where wells $\mathrm{G}$ and $\mathrm{H}$ are located, and the surrounding till and bedrock uplands. The study area is located in east-central Massachusetts in the City of Woburn, an industrialized suburb located 10 miles north of Boston. The proposed area to be simulated by the ground-water-flow model is the stratified-drift aquifer traversed by the Aberjona River (fig. 1). The project began in June 1985 and ended in March 1986.

\section{Approach}

Available data on geology (fig. 2), hydrology, weather, ground-water withdrawals, existing observation wells, streamflow, and water quality were gathered and compiled with the assistance of the USEPA and its contractors. A plan for location and construction of additional observation wells, piezometers, and streambed piezometers was prepared for implementation by the USEPA, and measurements of streamflow and groundwater levels were made prior to and during the aquifer test.

Geologic and hydrologic data were gathered during the drilling of new observation wells and during seismic-refraction surveys conducted along three east-west and two north-south lines in the valley (fig. 2). A 1-day step-drawdown test of well $G$ was conducted in November 1985 and of well $H$ 


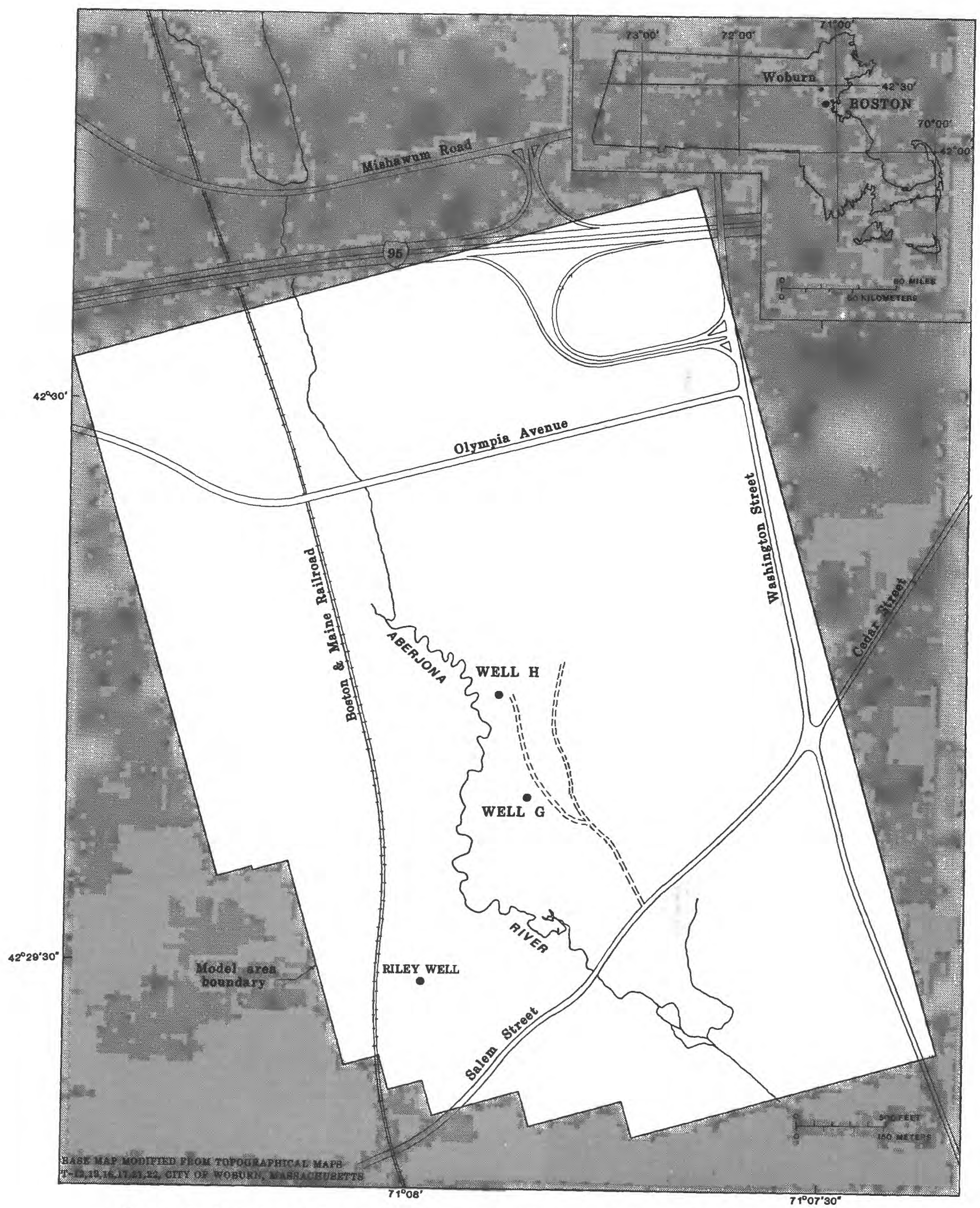

Figure 1.--Location of the study area and areal extent of the ground-water-model area. 


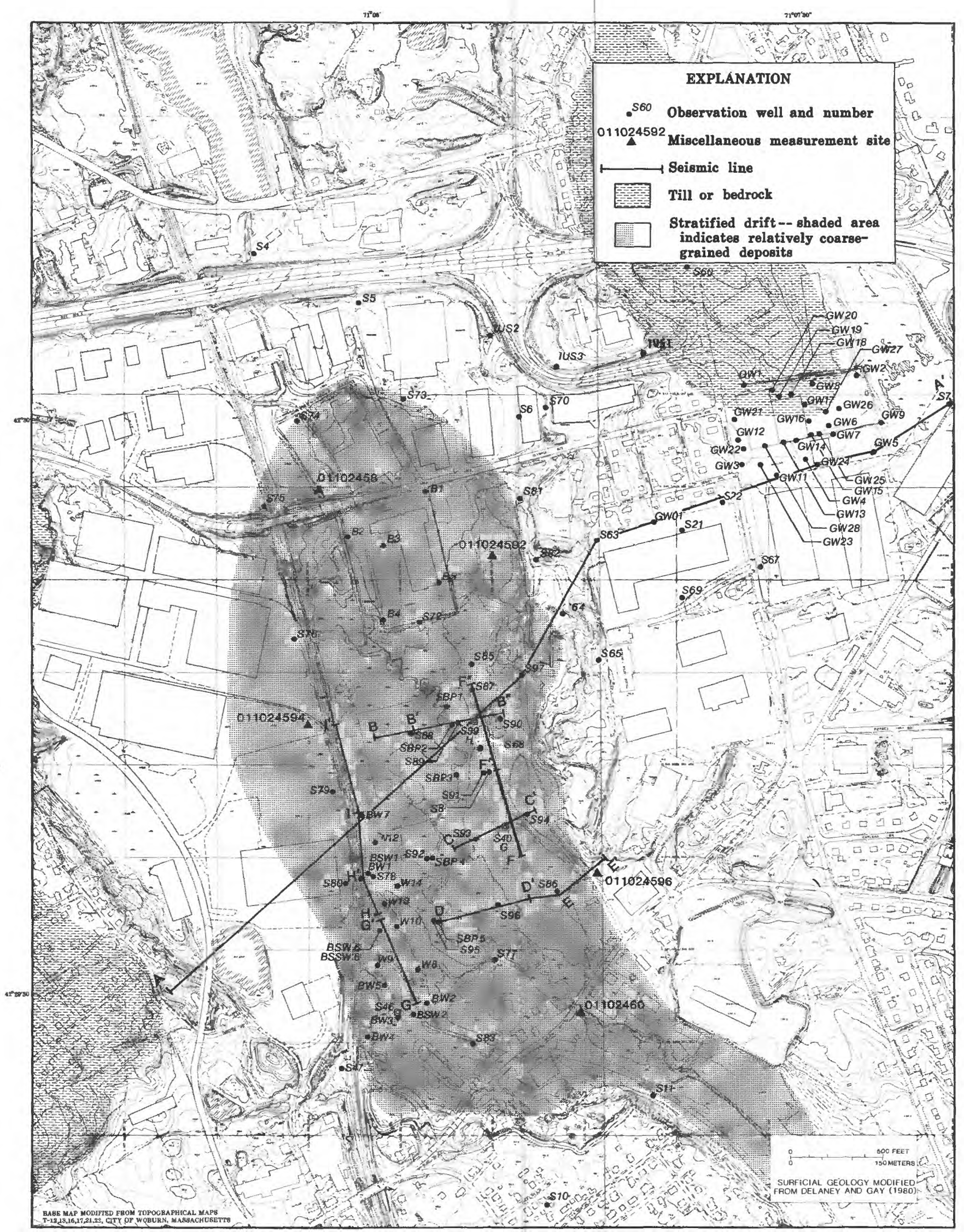

Figure 2.--Location of well sites, streamflow-gaging sites, seismic-refraction lines, and geologic section A-A . 
in December 1985, and a 30-day aquifer test of the wells was started on December 4, 1985, and ended on January 3,1986 . Preparation of a threedimensional ground-water-flow model began that simulates ground-water flow in the stratified-drift aquifer, discharge to streams, and withdrawal by wells. The model will be calibrated using the hydrologic data obtained from the 30-day aquifer test and will be designed as a predictive tool for testing steady-state and transient pumping effects of simulated wells in the vicinity of wells $G$ and $H$.

\section{Test Hole and Well-Numbering System}

Test holes and wells are identified by a unique local number based on an alphanumeric-coded system. The system has three parts: the first, a letter or series of letters identifying the owner of the well; the second, a sequential number assigned at the time the well was inventoried or installed; and the third, one- or two-digit letters (optional) designating the relative completion depth of the well. For example, well S88S installed by the USEPA was the 88th well location to be recorded and is a shallow well. The major exception in this numbering system is the wells drilled on the Beatrice Foods property (in the vicinity of seismic lines G$\mathrm{G}^{\prime}$ and $\mathrm{H}-\mathrm{H}^{\prime}$, fig. 2) where the relative completion depth is incorporated as part of the prefix letters. For example, well BSW6 installed by Beatrice Foods is a shallow well and was the 6th well cluster to be installed. For clarification, the well numbers on the illustrations in this report include the letter indicating completion depth. On the plates, the base map contains the number of the well site, where one or more wells may be located, and an accompanying table lists the number of the well site and the number of the specific well from which data were obtained.

\section{Acknowledgments}

The authors would like to thank the City of Woburn for cooperation in providing city records and for permission to conduct the aquifer tests of their wells. We would also like to thank the local landowners for allowing access to their properties, especially the Massachusetts Rifle Association, who provided shelter in their building during the wintertime aquifer test and unlimited access to their property for water-level measurements. Private consultants and associated field parties gen- erously supplied manpower and data during the aquifer tests. Special thanks are given to David Delaney and Barbara Newman of USEPA Region I for their dedicated effort and assistance all through the study.

Alan Klinger of the Survey maintained operation of the electronic field equipment during the aquifer tests and assisted in the input and conversion of field data into an extremely large computer database. Finally, Janet A. LeBlanc and Beth Johnson of the Survey made a major contribution to the preparation of the final report and its illustrations.

\section{HYDROGEOLOGY}

\section{Generalized Framework}

Ground water in the study area occurs in two principal formations--the bedrock underlying the entire area and the stratified drift, which overlies bedrock in most of the study area and in which wells $\mathrm{G}$ and $\mathrm{H}$ are screened. The two formations are separated in a few areas by a thin deposit of glacial till that is exposed at land surface in the northeastern and southwestern parts of the study area. A peat deposit of variable thickness and extent overlies the stratified drift throughout most of the wetland.

Ground water in the stratified drift generally is unconfined except where peat overlies the drift, and ground water in the bedrock is confined. The water table in the stratified drift and the potentiometric surface in the bedrock fluctuate continuously in response to changes in recharge and discharge. Recharge to stratified drift, till, and bedrock is from precipitation, and the general direction of ground-water flow is from upland areas east, west, and north of the valley to the wetland and the Aberjona River, which meanders through the valley. The stratified-drift aquifer becomes narrow and thin south of wells $\mathrm{G}$ and $\mathrm{H}$ and relatively little ground water from the aquifer flows out of the valley. Ground water discharges primarily to the river in the wetland area.

\section{Bedrock and Till}

The predominant bedrock type underlying most of the valley is a medium-grained igneous rock known as the Salem Gabbro-Diorite of early 
Paleozoic age. This rock is flanked on either side of the valley by a relatively more weathered and fractured medium-to-fine-grained igneous rock, the Dedham Granite of Late Proterozoic age (LaForge, 1932; Kaye, 1980). Water within the bedrock occurs largely in fractures and joints. Where fractures and joints are numerous, open, and wellconnected, significant quantities of water may be obtained.

Typically, wells completed in bedrock yield only a few gallons of water per minute. However, the Dedham Granite in the vicinity of well sites GW01 and S21 near Washington Street reportedly yielded in excess of $100 \mathrm{gal} / \mathrm{min}$ to a bedrock well (Delaney and Gay, 1980).

Seismic-refraction surveys were conducted by the Survey to determine aquifer thickness and depth to bedrock in areas where data were unavailable and in areas between existing wells where additional data were needed. Field data were collected using a 12-channel seismograph, and data were interpreted using a seismic-refraction inverse-modeling program (Scott and others, 1972; Scott, 1977), which is based on the timedelay method described by Pakiser and Black (1957). Six seismic lines were run in the study area (lines B-B", C-C', D-E', F-F"', G-G' ${ }^{\prime}$, and H$I^{\prime}$, fig. 2) A seventh line, not shown in figure 2, was run parallel to $\mathrm{B}^{-\mathrm{B}^{\prime}}$ to define the velocity of the peat layer. The results of the seismic surveys, together with the locations of the adjacent wells and a stratigraphic interpretation of the stratifieddrift aquifer, are illustrated in the geologic sections shown in figure 3.

Data from bedrock wells along the seismic lines confirm that the altitude of the bedrock surface as defined by the surveys is accurate to within 10 percent. Three distinct velocity layers characteristic of the stratified drift, bedrock, and peat were determined. Velocities ranging from 4,273 to $8,274 \mathrm{ft} / \mathrm{s}$ were found to be characteristic of the saturated stratified-drift while velocities ranging from 15,159 to $24,201 \mathrm{ft} / \mathrm{s}$ were characteristic of the underlying crystalline bedrock. A velocity of $1,778 \mathrm{ft} / \mathrm{s}$ was determined for the peat deposit in the wetland. The velocities are typical of saturated alluvial deposits and crystalline bedrock in New England (Haeni, 1986).

The depth to bedrock from land surface ranges from zero, where bedrock crops out at several locations along the eastern and western sides of the valley, to approximately 140 feet in the center of the valley near well sites S93 and S77. The primary axis of the bedrock valley is northnorthwest/south-southeast parallel to the orientation of the Aberjona River. The seismic-refraction and test-drilling data reveal the locations of several bedrock hills and depressions in the study area which haye important effects on the local groundwater-flow system. Bedrock hills are present between well sites S88 and S89 (section B-B", fig. 3) in the center of the valley west of well $\mathrm{H}$, between wells $\mathrm{G}$ and $\mathrm{H}$ beneath well site $\mathrm{S} 68$ (section F$\left.F^{\prime \prime}\right)$, northeast of well site S90 (fig. 2), and between well sites W9 and W10 (section G-G') on the western side of the river valley. The available data suggest that these hills form several more or less continuous ridges which cross all or part of the valley. The two most important bedrock ridges are located in the vicinity of well sites W9 and W10, where one ridge is near land surface and extends between the Aberjona River and the western side of the valley, and on the eastern side of wells $G$ and $\mathrm{H}$, where another ridge (or a bedrock valley wall) forms a steep-sided slope beneath and parallel to the hillslope on the eastern side of the valley. The location of the deepest depression of the bedrock surface coincides almost exactly with the current position of the river channel.

Till, which is composed of clay, silt, sand, gravel, and boulders, is found primarily on hilltops in the northeastern and southwestern parts of the study area (fig. 2). Most of the till is very similar in composition to the stratified drift (Castle, 1959). Lodgement till observed in several well borings immediately above the bedrock is compacted and relatively dense. Reported yields of wells constructed in till are generally less than a few gallons per minute (Delaney and Gay, 1980).

\section{Stratified-Drift Aquifer}

\section{Description}

The stratified drift is composed primarily of sand and gravel and yields the largest quantities of water for public water supply in the area. The thickness of the drift ranges from zero along parts of the eastern and western sides of the valley to approximately 140 feet in the vicinity of well sites S77 and S93. Relatively coarse-grained stratified drift occurs beneath the wetland in the vicinity of wells $\mathrm{G}$ and $\mathrm{H}$. 

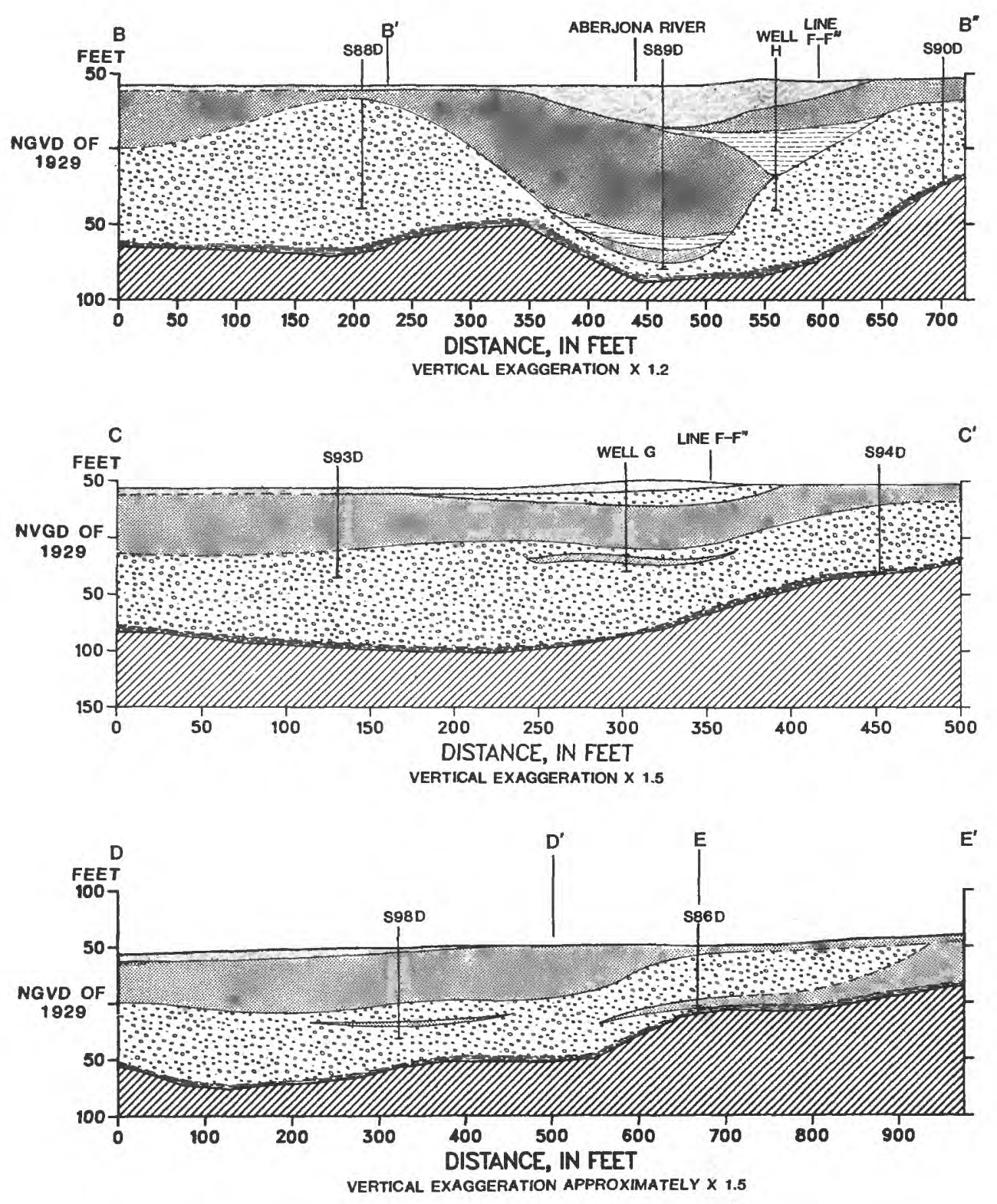

\section{EXPLANATION}

\begin{tabular}{llll}
\hline PEAT & PILT. SAND & FINE TO & MEDIUM SAND \\
1 & APPROXIMATE LOCATION OF BOTTOM OF BOREHOLE &
\end{tabular}

Figure 3.--Geologic sections of the Aberjona River valley. 

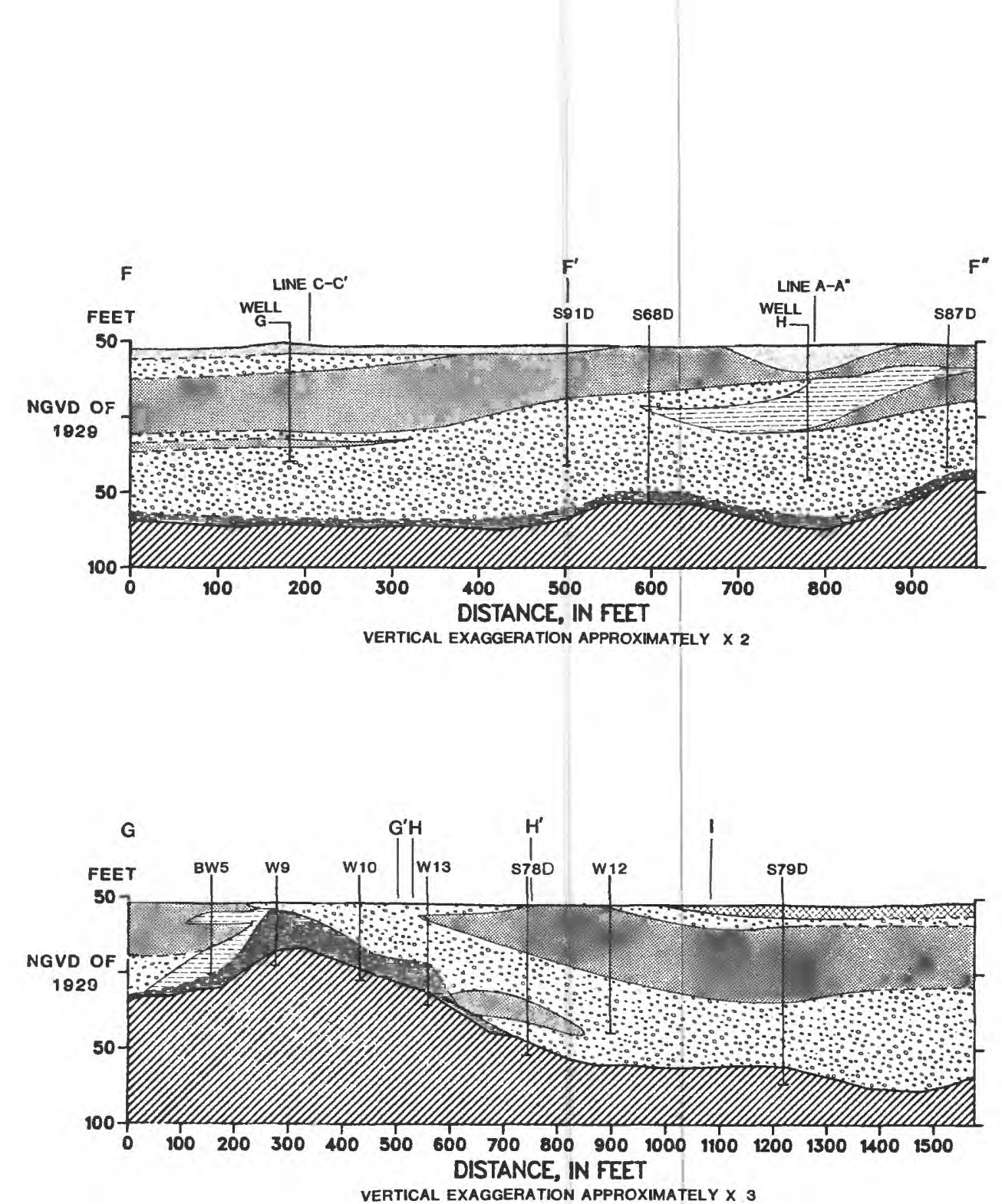

VERTICAL EXAGGERATION APPROXIMATELY X 3

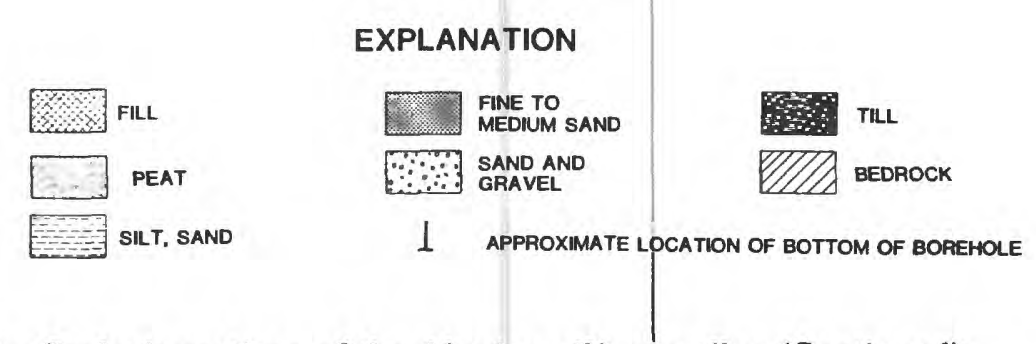

Figure 3.--Geologic sections of the Aberjona River valley (Continued). 
Although the lithology of the stratified drift varies locally both horizontally and vertically, the drift can be separated into three stratigraphic layers (fig. 4). The uppermost layer is comprised of sand, silt, clay, deposits of peat, and a few areas of silt and fine sand, and ranges in thickness from 0 to 25 feet. It is underlain by an intermediate layer of fine-to-coarse sands that ranges in thickness from 10 to 50 feet. The lowermost stratified-drift layer is composed of coarse sand and gravel that ranges in thickness from 20 to 50 feet. Wells G and $\mathrm{H}$ are screened in this lower layer.

Yields to wells screened in the stratified drift are largely dependent upon the composition of the drift. According to Delaney and Gay (1980), some areas of the stratified drift may yield more than $500 \mathrm{gal} / \mathrm{min}$. The estimated transmissivity of the stratified drift in the coarsest grained deposits in the center of the river valley exceeds $4,000 \mathrm{ft}^{2} / \mathrm{d}$ (Delaney and Gay, 1980).

A peat deposit partially confines ground water in the stratified drift beneath the wetland. The peat deposit underlies most of the wetland in the study area and forms a nearly continuous layer on top of the stratified drift. In most of the area, the thickness of the peat ranges from 2 to 7 feet. However, test drilling at well site S89 encountered about 26 feet of peat. Core samples of streambed sediments and of peat material immediately below the streambed indicate that streambed sediments are composed of silt and sand ranging in thickness from 0.5 to 2 feet and are underlain by peat up to 7 feet thick. There are no data on the hydraulic properties of the peat deposits in the valley; published estimates of vertical hydraulic conductivity for peat range from 0.001 to $0.1 \mathrm{ft} / \mathrm{d}$ (Siegel and Ericson, 1980). Core samples obtained during drilling, together with the relatively low velocities obtained from seismic-refraction tests, indicate that the peat is a relatively loose, nearly saturated material which permits ground-water discharge to the river under normal conditions and induced infiltration of streamwater under pumping conditions.

\section{Water Table}

Within the last 5 years, more than 100 observation wells have been installed in the study area to record water-table fluctuations and collect water samples. In October 1985, the USEPA installed an additional 34 wells near wells $G$ and $H$ and in the adjacent wetland. Altogether, there are more than 134 observation wells at 72 locations (fig. 2). Most of the well locations have groups of wells that are screened in both the stratified drift and bedrock. In addition, 10 piezometers were installed at 5 locations along the stream upgradient and downgradient of wells $\mathrm{G}$ and $\mathrm{H}$ to monitor hydraulic-head differences across the streambed and the peat layer. The diameters of the observation wells range from 1.25 to 2 inches and completion depths range from 2 to 138 feet. Plate 1 shows the altitude of the water table and the general direction of ground-water flow as of December 4, 1985, prior to the start of a 30-day aquifer test.

The altitude ${ }^{2}$ of the water table ranges from about 40 feet above the National Geodetic Vertical Datum of 1929 (NGVD of 1929) in the wetlands near well site S96 to over 94 feet above NGVD of 1929 beneath the hill in the northeastern part of the study area near well site GW8. Relatively steep water-table gradients occur near Washington Street and along the steep hillslope which forms the eastern side of the valley. Relatively gentle gradients occur across the wetland. The water table commonly is at or near land surface in most of the low-lying areas, and 10 to 15 feet below land surface in hilly areas on the eastern and western sides of the study area. Plate 2 shows the altitude of the potentiometric surface of the lowermost portion of the stratified-drift aquifer on December 4, 1985, as determined from wells completed in the deepest part of the stratified drift and in bedrock just beneath the stratified drift.

\section{Direction of Ground-Water Flow}

The principal direction of ground-water flow on the western side of the Aberjona River valley is southeast on an average horizontal gradient of $0.005 \mathrm{ft} / \mathrm{ft}$ (pl. 1). Vertical hydraulic-head gradients in the stratified drift range from $0.002 \mathrm{ft} / \mathrm{ft}$ at well site S79 where vertical flow is downward to $0.0006 \mathrm{ft} / \mathrm{ft}$ at well sites S92 and S95 where vertical flow is upward.

Water in the stratified drift east of the Aberjona River flows toward the southwest with an average horizontal gradient of $0.02 \mathrm{ft} / \mathrm{ft}$. Vertical hydraulic-head gradients on the eastern side of the valley generally are greater than those on the western side of the valley. Vertical gradients

${ }^{2}$ Altitude, as used in this report, refers to distance above or below the NGVD of 1929 . 


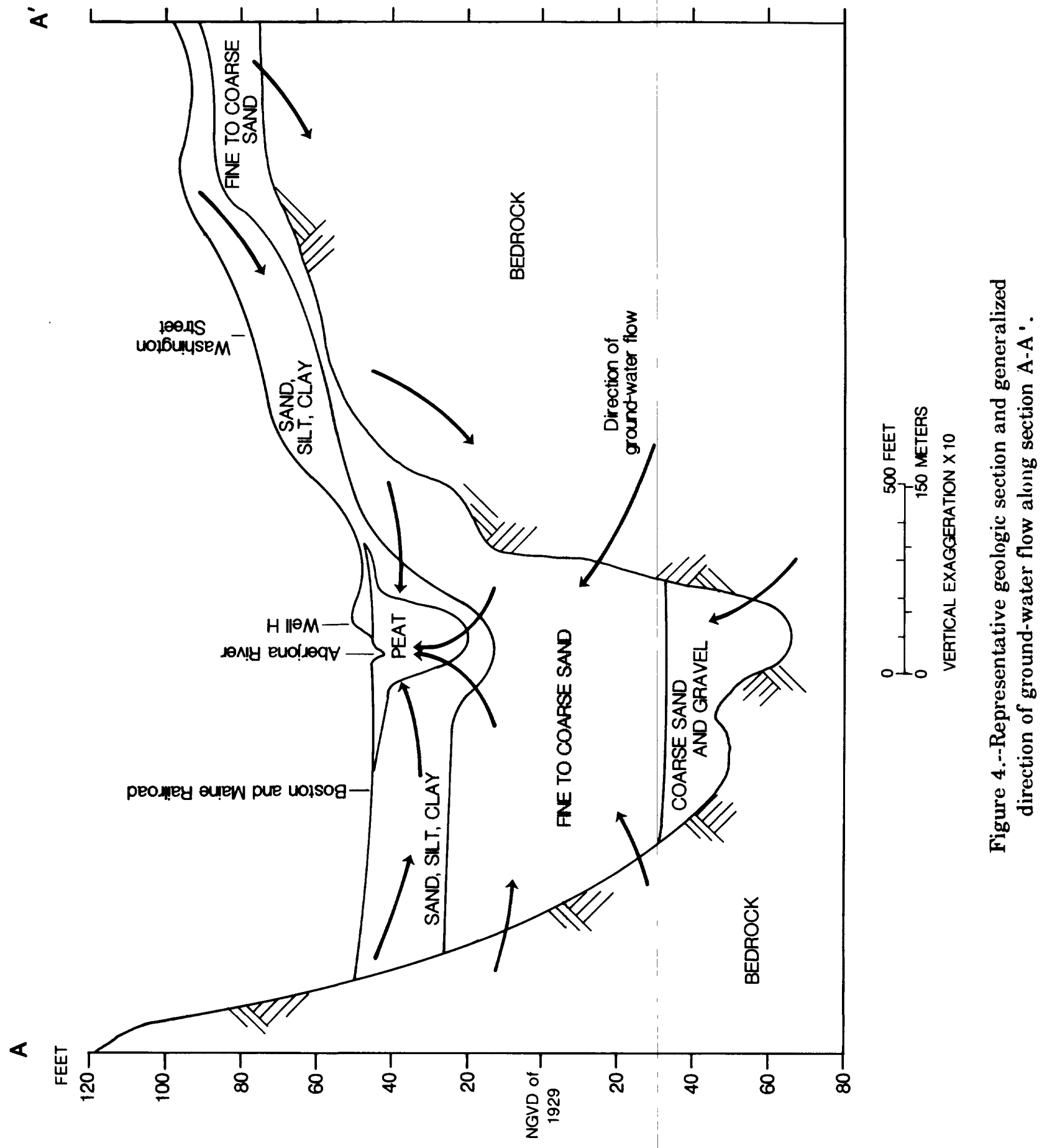


range from $0.008 \mathrm{ft} / \mathrm{ft}$ to $0.01 \mathrm{ft} / \mathrm{ft}$ and downward vertical flow is indicated at all wells. Vertical upward gradients in the wetland east of the Aberjona River (well sites S89 and S93) also are greater than those in the wetland on the western side of the river, averaging $0.003 \mathrm{ft} / \mathrm{ft}$.

The direction of ground-water flow in the center of the valley is southward, parallel to the axis of the valley with an average horizontal gradient of $0.001 \mathrm{ft} / \mathrm{ft}$. Vertical head gradients in the center of the valley are all upward toward the streambed of the Aberjona River.

The long-term pumpage from the Riley well (fig. 1, S46 on all base maps) causes a cone of depression to form in the southwestern part of the river valley resulting in a local change in the ground-water-flow direction. Pumpage of the Riley well intercepts ground-water discharge from the stratified drift and bedrock west of the study area and causes flow toward the well. As a result, a ground-water divide is present in the vicinity of well sites S96 and S77 marking the dividing line between eastward- and westward-moving ground water in that area. Another ground-water divide occurs in the northeastern part of the study area east of Washington Street in the vicinity of well sites GW6, GW8, and GW27. This area represents the highest altitude in the study area and the water table on the eastern edge of the study area slopes southeast away from the center of the valley at a gradient of $0.004 \mathrm{ft} / \mathrm{ft}$.

The general directions of ground-water flow interpreted from the horizontal and vertical hydraulic-head data are illustrated in figure 4 . Under normal conditions (Riley well pumping, wells $G$ and $H$ not pumping), ground water moves vertically downward and laterally through the stratified drift in the upland areas of the valley. In the vicinity of the wetland, ground water from the bedrock and stratified drift flows vertically upward through the drift and peat to discharge in the wetland and river. Relatively small amounts of ground water enter the Aberjona River valley from upgradient areas north of Interstate 95 (fig. 2) and exit the narrow, southern end of the valley south of Salem Street. Ground-water in the vicinity of the Riley well is directed toward the well.

\section{Ground-Water Withdrawals}

Well G was constructed in October 1964 and is completed to approximately 85 feet below land surface. The well is constructed of 24-inchdiameter steel casing and the bottom 10 feet is screened between 25.5 and 35.5 feet below NGVD of 1929. The well is gravel packed to within 10 feet of the land surface and grouted to land surface.

Well $\mathrm{H}$ was constructed in July 1967 and is completed to approximately 88 feet below land surface. The well is constructed of 24-inchdiameter steel casing and the bottom 10 feet of the well is screened between 35.0 and 45.0 feet below NGVD of 1929. The well is gravel-packed to within 10 feet of the land surface and grouted to land surface. Historically, both wells were pumped continuously during the summer months each year at a rate of 700 to $800 \mathrm{gal} / \mathrm{min}$ for well $\mathrm{G}$ and 400 $\mathrm{gal} / \mathrm{min}$ for well $\mathrm{H}$ (Thomas J. Merin, City Engineer, Woburn, Mass., written commun., 1980). The specific capacity of well $G$ following its last overhaul in March 1978 was approximately 35 (gal/min)/ft, and the specific capacity of well $\mathrm{H}$ following its last overhaul in February 1977 was approximately $40(\mathrm{gal} / \mathrm{min}) / \mathrm{ft}$. The wells were closed in May 1979 because of contamination by volatile organic compounds.

The Riley well (S46) pumps approximately $700 \mathrm{gal} / \mathrm{min}$ during normal, weekly working hours and operated when wells $G$ and $H$ were pumped for water supply. Delaney and Gay (1980) reported that two other wells are located in the area: A bedrock well located approximately 750 feet east of well $\mathrm{G}$ that is used intermittently, and an abandoned bedrock well northeast of well $H$ near well site S21 that was reported capable of yielding 110 $\mathrm{gal} / \mathrm{min}$, and was pumped at unspecified intervals between 1958 and 1977.

\section{AREA OF INFLUENCE AND ZONE OF CONTRIBUTION TO SUPERFUND-SITE WELLS G AND H}

The area of influence and zone of contribution to wells $\mathrm{G}$ and $\mathrm{H}$ under pumping conditions was determined from a 30-day aquifer test of the wells conducted in December 1985. Before describing the results of the test, the following discussion summarizes the general hydrologic conditions in the river valley prior to the start of the test, the results of preliminary testing of the wells during their refurbishment, and the events of 30-day aquifer test. 


\section{Hydrologic Conditions in the Aberjona River Valley, Fall 1985}

Stream-discharge data were collected from August 1985 to February 1986 to determine net gains or losses of streamflow of the Aberjona River in the vicinity of wells $G$ and $H$. Streamflow of the Aberjona River into the wetland was measured at four sites (fig. 2): Olympia Avenue near Woburn (01102458), located 150 feet north of Olympia Avenue; tributary 1 (011024592), located approximately 250 feet west of well site $\mathrm{S} 82$; tributary 2 (011024594), located 400 feet north of well S79; and tributary 3 (011024596), located 250 feet east of well S86. Surface-water outflow from the area was measured on the Aberjona River at Salem Street, (01102460), 2 feet south of the Salem Street bridge. Stream-discharge measurements were made following techniques described by Rantz and others (1982).

Beginning 3 months prior to the aquifer test, streamflow measurements were made weekly at the Olympia Avenue and Salem Street locations. On the first day of the 30-day aquifer test, streamflow measurements were made approximately hourly at each of the sites to determine impacts of pumpage from wells $\mathrm{G}$ and $\mathrm{H}$ on streamflow. Subsequently, streamflow measurements were made periodically during the aquifer test to quantify the long-term effects of pumpage. The discharge measurements collected during this study are presented in table 1. Net gain or loss of streamflow was computed by subtracting outflow of the Aberjona River at Salem Street from the sum of inflow of the Aberjona River at Olympia Avenue and the three tributaries.

For comparison, long-term flow and corresponding flow durations of the Aberjona River at Winchester, located about 3 miles south of the study area, and the Parker River.at Byfield, located about 20 miles northeast of the study area, are included in table 1 . Flow-duration values indicate the percentage of time daily flow was equaled or exceeded during the period of record. This provides a comparison of flow in the Aberjona River at Salem Street (drainage area $6.91 \mathrm{mi}^{2}$ ) with historical records of the Aberjona River at Winchester (drainage area $24.1 \mathrm{mi}^{2}$ ). However, flow of the Aberjona River is influenced by pumpage and dams upstream; consequently, the flow records are not truly representative of natural-flow conditions. The flow-duration record for Parker River at Byfield (drainage area $21.3 \mathrm{mi}^{2}$ ) is included because it is an unregulated stream with flow durations and drainage characteristics similar to those of the Aberjona River at Winchester. Large differences in flow duration on August 29, September 26, and January 3 are the result of streamflow regulation on the Aberjona River at Winchester. Low-flow duration percentages represent above-average flow compared to the period of record, while high percentages represent below-average flow.

Streamflow net losses and gains between the inflow and outflow sites on the river for the measurement period ranged from $-1.45 \mathrm{ft}^{3} / \mathrm{s}$, which occurred near the end of the 30-day aquifer test, to $+5.1 \mathrm{ft}^{3} / \mathrm{s}$, which occurred during relatively highflow conditions several weeks before the start of the test. During low-flow conditions when most measurements were made, the Aberjona River reach flowing through the study area gained between 0.10 and $0.62 \mathrm{ft}^{3} / \mathrm{s}$. With the exception of the September 20,1985, discharge measurement, all measurements of stream discharge during the 3 months prior to the 30-day aquifer test indicated a net streamflow gain between the inflow and outflow-measuring sites.

Hydrologic conditions in the region (precipitation, ground-water levels, and streamflows) during the fall 1985 were near normal. However, from late-November 1985 to late-January 1986, precipitation was below normal, which caused below normal ground-water levels. The hydrograph of the nearest well in the Survey's statewide groundwater observation-well network (Wilmington 78), as well as streamflow in the Aberjona River at Winchester and the barometric pressure and precipitation in Boston for the period November 1, 1985-January 31, 1986, are illustrated in figure 5 .

\section{Aquifer Tests}

\section{Step Drawdown}

A 7.5-hour step-drawdown test was performed on well G on November 27, 1985 . The test was conducted using four pumping rates, beginning at a low pumping rate and increasing pumpage at 2 hour intervals with the exception of the last interval which was 1.5 hours in length. The pumping rates were $330,440,520$, and $640 \mathrm{gal} / \mathrm{min}$, respectively. Prior to the start of the test, water levels were measured in 22 observation wells and in the production well. Drawdowns measured at the end of each step (Appendix A) were used to 
Table 1.--Summary of miscellaneous discharge measurements in the vicinity of wells $G$ and $H$ and comparison of flow duration in nearby rivers

[All streamflow is given in cubic feet per second; a dash indicates no measurement.]

\begin{tabular}{|c|c|c|c|c|c|c|c|c|}
\hline \multirow[b]{2}{*}{ Date } & & \multicolumn{3}{|c|}{ Inflow } & Outflow & \multicolumn{3}{|c|}{$\begin{array}{l}\text { Percentage of } \\
\text { flow duration }\end{array}$} \\
\hline & $\begin{array}{c}\text { Aberjona } \\
\text { River } \\
\text { Olympia } \\
\text { Avenue } \\
01102458\end{array}$ & $\begin{array}{c}\text { Aberjona } \\
\text { River } \\
\text { tribu- } \\
\text { tary } 1 \\
011024592\end{array}$ & $\begin{array}{c}\text { Aberjona } \\
\text { River } \\
\text { tribu- } \\
\text { tary } 2 \\
011024594\end{array}$ & $\begin{array}{c}\text { Aberjona } \\
\text { River } \\
\text { tribu- } \\
\text { tary } 3 \\
011024596\end{array}$ & $\begin{array}{c}\text { Aberjona } \\
\text { River } \\
\text { Salem } \\
\text { Street } \\
01102460\end{array}$ & $\begin{array}{l}\text { or } \\
\text { loss (-) }\end{array}$ & $\begin{array}{c}\text { Aberjona } \\
\text { River } \\
\text { at } \\
\text { Winchester } \\
01102500\end{array}$ & $\begin{array}{c}\text { Parker } \\
\text { River } \\
\text { at } \\
\text { Byfield } \\
01101000\end{array}$ \\
\hline
\end{tabular}

1985

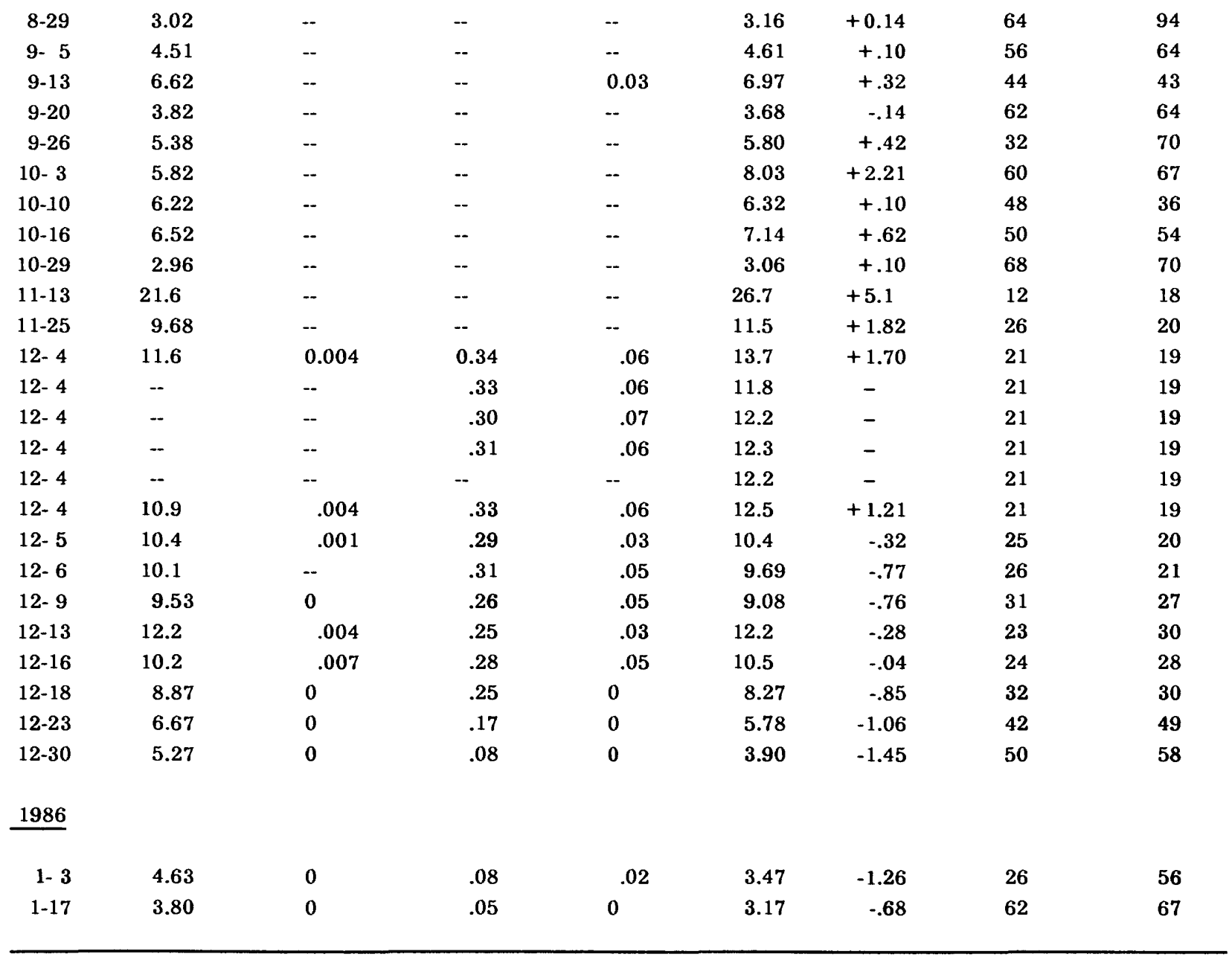



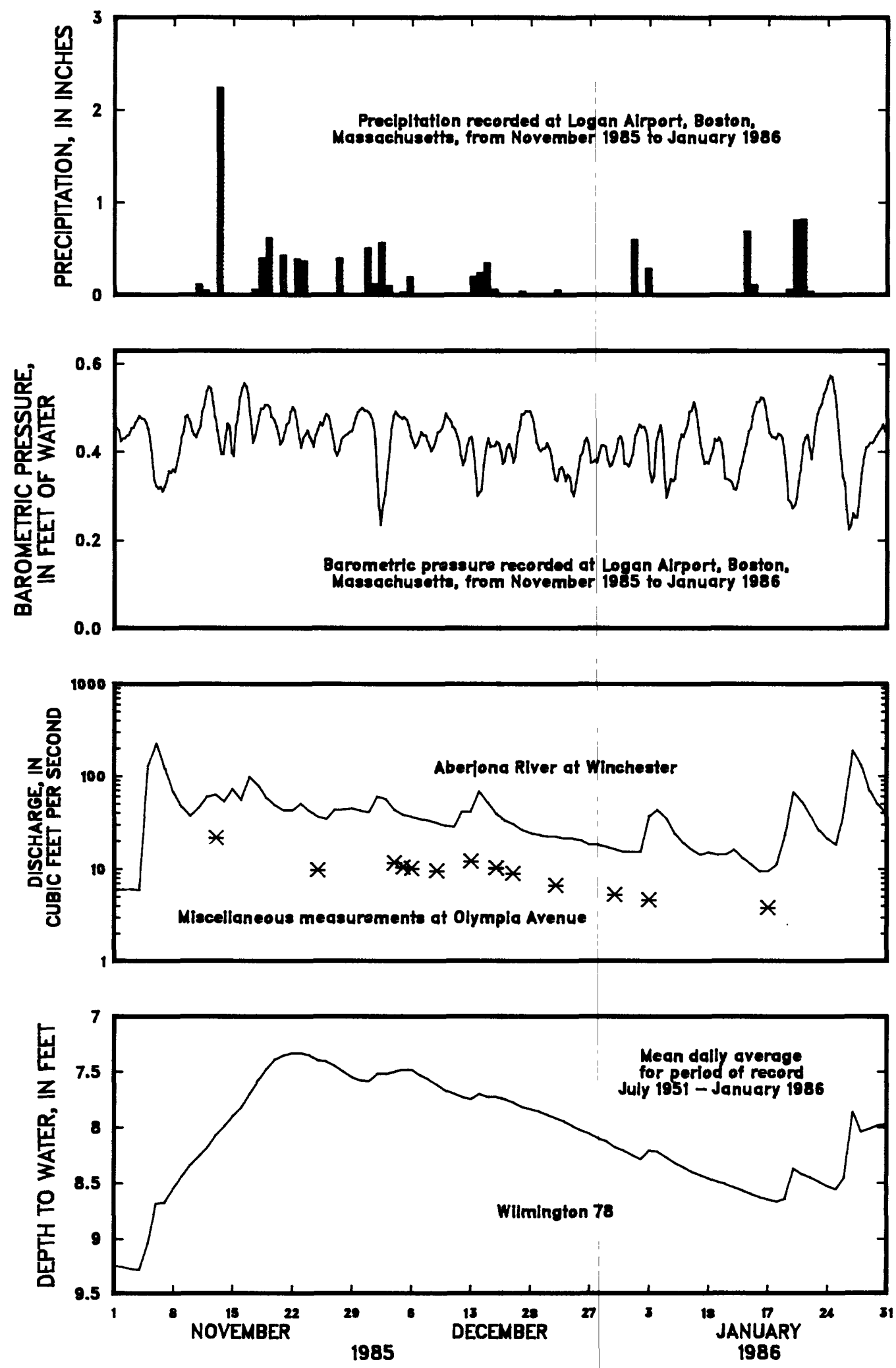

Figure 5.--Precipitation, barometric pressure, stream discharge, and ground-water levels near wells $G$ and $H$, from November 1, 1985, to January 31, 1986. 
calculate an average specific capacity of 27.5 (gal/min)/ft. Transmissivity of the aquifer at well G was estimated to be approximately $10,000 \mathrm{ft}^{2} / \mathrm{d}$, using the graphical relation between specific capacity and transmissivity described by Walton (1970, p. 317), with an adjustment of the specific capacity because of partial penetration effects (Walton, 1970; eq. 5-18).

As a check on the value derived by the graphical method, the transmissivity of the aquifer also was calculated by using the observation-well timedrawdown method described by Boulton (1963, in Lohman, 1972, eq. 109). For well S94D, located $140 \mathrm{ft}$ from well $\mathrm{G}$, a transmissivity of 29,700 $\mathrm{ft}^{2} / \mathrm{d}$ was determined (Appendix A). The storage coefficient for the unconfined aquifer of was calculated as 0.20 according to the method defined by Boulton (1963 in Lohman, 1972, eq. 106). Average horizontal hydraulic conductivity of the stratified drift in the vicinity of well $G$ was estimated to range from 125 to $350 \mathrm{ft} / \mathrm{d}$ by assuming a saturated thickness of the stratified-drift aquifer of $80 \mathrm{ft}$.

A 7-hour, step-drawdown test was performed on well $\mathbf{H}$ on December 2, 1985. The test was conducted by using 4 pumping rates beginning at a low pumping rate and increasing pumping at 2hour intervals with the exception of the last interval which was 1 hour in length. Pumping rates were $230,330,400$, and $475 \mathrm{gal} / \mathrm{min}$ respectively. Prior to the start of the test, water levels were measured in 22 observation wells and in the production well. The average specific capacity of the well determined from the drawdowns observed at the end of each step was 29.1 ( $\mathrm{gal} / \mathrm{min}$ )/ $\mathrm{ft}$ (Appendix A). Estimated transmissivities ranged from $10,700 \mathrm{ft}^{2} / \mathrm{d}$ (Walton, 1970; p. 317) to 17,600 $\mathrm{ft}^{2} / \mathrm{d}$ (Boulton, 1963, in Lohman, 1972, eq. 109). The storage coefficient was determined to be 0.16 . The average horizontal hydraulic conductivity of the stratified drift in the vicinity of well $\mathrm{H}$ was estimated to range from 130 to $215 \mathrm{ft} / \mathrm{d}$ by assuming a saturated thickness of $82 \mathrm{ft}$.

\section{Thirty-Day Aquifer Test}

A 30-day aquifer test of wells $\mathrm{G}$ and $\mathrm{H}$ was started on December 4, 1985, and finished on January 3,1986 . Both wells $G$ and $H$ were turned on simultaneously and pumped at a rate of 700 $\mathrm{gal} / \mathrm{min}$ and $400 \mathrm{gal} / \mathrm{min}$, respectively, for the $\mathrm{du}$ ration of the test. On the first day of the test, aquifer and stream response to pumping were determined by measuring water levels in 127 obser- vation wells at 72 well sites and in 10 streambed piezometers at five stream sites. Streamflow into and out of the study area was measured hourly. For the duration of the test, water-levels in a selected number of wells were recorded continuously, while levels in remaining wells were recorded intermittently by hand methods. Appendix B contains the hydrographs of nearly all wells used for observation during the test. The altitude of the water table in the study area on December 4, 1985 prior to the start of the test is illustrated on plate 1 , and the altitude of the potentiometric surface of the lowermost portion of the stratified-drift aquifer prior to the start of the test is shown on plate 2 . Streamflow was measured intermittently throughout the test. Stream-discharge measurements made at five locations along the Aberjona River and its tributaries (table 1) showed that just before the start of the test, streamflow entering the wetland was approximately $12.0 \mathrm{ft}^{3} / \mathrm{s}$, while flow leaving the wetland was $13.7 \mathrm{ft}^{3} / \mathrm{s}$, resulting in a net gain of $1.7 \mathrm{ft}^{3} / \mathrm{s}$.

Several days of cold weather froze the ground surface prior to the start of the test. Precipitation from a rainfall event the day before the test ran off the frozen surface and entered the Aberjona River, flooding the wetland. Recharge to the aquifer was noticed as rising water levels in each of the observation wells just before the start of the test. Because of the cold temperatures the morning of the test, the pumps were started intermittently for periods up to a minute to dislodge ice in the discharge lines. Within a few hours of the noontime start of the test, the level of water in the wetland in the immediate vicinity of wells $G$ and $H$ dropped approximately 3 inches and the wetland dried up, as indicated by the exposed thin layer of ice which was left behind attached to wetland vegetation.

During the test, pump failure was experienced once at each well. The first failure occurred at well $\mathrm{G}$ after 31 hours of pumping and lasted for 2 hours. The second failure occurred at well $\mathrm{H}$ after 14 days of pumping and lasted for only a few minutes. In each case, water levels began to rise in the observation wells but returned to pre-failure levels shortly after the pumping resumed. On the seventh, eighth, and ninth days of the test, 0.2 , 0.24 , and 0.35 inches of precipitation, respectively, were recorded at Logan Airport, Boston, Massachusetts (fig. 5). The precipitation produced both an increase in streamflow because of runoff and a rise in water levels as indicated in most of the observation wells and the control well, Wilm- 
ington 78. During most of the test, which took place during the Christmas holiday period, the Riley well was pumped intermittently. Pumping cycles and withdrawal-rate data for that well were unavailable for use in this study.

The drawdown of the water table after 30 days of pumpage from wells $G$ and $H$ is shown on plate 3 , and the water-level decline of the potentiometric surface in the lowermost stratified drift is shown on plate 4 . Plates 5 and 6 show the corresponding altitude of the water table in the stratified-drift aquifer and the potentiometric surface of the lowermost part of the stratified-drift aquifer at the end of the test

The total amount of drawdown at well $G$ was $22.4 \mathrm{ft}$, whereas, that at well $\mathrm{H}$ was $16.4 \mathrm{ft}$, a difference representative of the relative rates of pumpage from both wells. Within 24 hours after the start of the aquifer test, hydraulic gradients in the vicinity of wells $\mathrm{G}$ and $\mathrm{H}$ beneath the Aberjona River were reversed, causing downward vertical leakage in the peat layer. Net streamflow losses were measured during the aquifer test reached a maximum loss of $1.45 \mathrm{ft}^{3} / \mathrm{s}$ on December 30 , 1985. At the end of the test, wells $G$ and $H$ were removing $1.26 \mathrm{ft}^{3} / \mathrm{s}$ from the stream as induced infiltration of surface water from the wetland and the Aberjona River and as intercepted groundwater discharge. The streamflow data gathered after the aquifer test indicated that after 2 weeks of recovery, surface water still was being induced from the stream to replace water removed from storage in the stratified drift during pumping.

The water-level data obtained from the aquifer test were used to determine the area of influence and zone of contribution to wells $G$ and $H$ under pumping conditions. These features are described in detail in the following section.

\section{Area of Influence}

During the month-long test, a water-level decline of 1 foot occurred in stratified-drift deposits in the Woburn area, according to the water-level data from the Survey's long-term observation well in the area (Wilmington 78, fig. 5). Drawdown of water-levels in observation wells in the vicinity of wells $G$ and $H$ was used to define the cone of depression of the water table caused by pumping. In this report, the area of influence of wells $G$ and $H$ is defined as that area of the cone of depression in which water-level declines exceed 1 foot.
The area of influence of wells $\mathrm{G}$ and $\mathrm{H}$ at the end of the 30-day aquifer test, as measured at the water table in the upper stratified drift, is illustrated on plate 3 . The area is oblong in shape with a long axis oriented northwest-southeast, parallel to the axis of the river valley. The area of influence is approximately 3,000 feet long and 1,700 feet wide, as measured at the midpoint between wells $\mathrm{G}$ and $\mathrm{H}$, and comprises an area in which drawdown ranges from 1 to 22.4 feet.

The drawdown data indicate that wells $G$ and $\mathrm{H}$ influence the altitude of the water table in an area which extends from the north end of the wetland near Olympia Avenue, approximately 1,100 feet north of well $\mathrm{H}$, to about 300 feet south of Salem Street $(1,200$ feet south of well G) at the south end of the river valley. To the west and northwest, the water table is influenced by pumping at least 1,200 feet from well $H$. The full westward extent of influence is unknown because no water-level data were collected during the test on the far western side of the valley. The eastern limit of the area of influence is relatively close to the wells and coincides approximately with the midpoint of the hillslope which defines the eastern side of the river valley. The eastern limit is within 500 feet of wells $G$ and $H$, and, east of this line, no measurable effects on the altitude of the water table were detectable as a result of pumping.

The shape and size of the area of influence of wells $G$ and $H$ in the upper stratified drift is caused primarily by a combination of three factors: (1) the two pumping wells are located on a northsouth axis which elongates the cone of depression around the wells; (2) the Aberjona River to the west flows along a course more or less parallel to the wells and leaks water to the aquifer under pumping conditions; and (3) a steep hillslope east of the wells marks the location of a steep, westfacing, near-surface bedrock boundary (fig. 4) which has a significant control on ground-water flow on this side of the valley. The thin stratified drift and the bedrock boundary form an effective hydraulic boundary in the local ground-water-flow system, particularly when wells $G$ and $H$ are pumped. The boundary minimizes drawdowns caused by the pumping wells east of its location but contributes to relatively large drawdowns between the wells and the side of the valley. In the area east of wells $G$ and $H$, relatively small amounts of water are obtained from aquifer storage, intercepted ground-water discharge in the stratified drift, and leakage from bedrock to satisfy 
the demands of the pumping wells. Thus, the area of influence extends northward, westward, and southward to include an aquifer area sufficient to satisfy the remaining demand of the wells. The amount of water-table drawdown north, west, and south of the wells is less than that east of the wells because water is supplied not only from aquifer storage and intercepted ground-water discharge, but also from induced infiltration from the river.

In the lowermost part of the stratified-drift aquifer in which wells $G$ and $H$ are screened, the shape of the area of influence (pl. 4) is similar to that observed in the uppermost stratified-drift aquifer (pl. 3); however, the size of the area is much larger. The location of the eastern edge of the area of influence is the same as that measured at the water table and is due to the hydrologic effect of the bedrock boundary. The aquifer-test data clearly show that pumping causes a greater drop in hydraulic head in the deepest parts of the aquifer north, west, and south of the wells than in the shallowest part of the aquifer. The relatively large area of influence in the deep aquifer is caused by a combination of factors, the most important of which are the reduced size of the aquifer at depth; the semi-confined conditions of the stratified drift; the reduction in the amount and number of sources of water to the wells; and, to some extent, the hydraulic effects created by pumpage from partially penetrating well screens.

It is very important to note that the shape and size of an area of influence of any well pumping from the sand and gravel aquifer in the vicinity of wells $\mathrm{G}$ and $\mathrm{H}$ is neither constant in area nor fixed with respect to time. The size of the area of influence of wells such as $G$ and $H$ is dependent upon the rate and duration of pumpage and on hydrologic conditions. For example, increased pumping or long pumping periods may increase the size of the area of influence. Conversely, above-average recharge to the sand and gravel aquifer and relatively high water-table conditions may decrease the size of the area of influence. In summary, the area of influence of wells $\mathrm{G}$ and $\mathrm{H}$ described in this report is considered to be a "snapshot" representative of an average area of influence. Although the wells were pumped for a period somewhat shorter than historical pumping periods and hydrologic conditions were somewhat drier than normal, the amount and extent of drawdown observed and the amount of streamflow reduction due to induced infiltration were very similar to those conditions that have been observed at numerous other public water-supply sites in the region.

\section{Zone of Contribution}

Wells $\mathbf{G}$ and $\mathbf{H}$ obtain water from an area of aquifer, or zone of contribution, that may be divided into two parts. Most of the water pumped by the wells is obtained directly from that part of the aquifer immediately surrounding both wells and from induced infiltration of surface water from the overlying river and wetland. Specifically, this area includes a part of the aquifer and wetland on the eastern side and western sides of the river. Water also is obtained from a small area south of the wells, and a limit can be determined which marks the dividing line between the area in which ground water flows toward well $G$ and the area in which ground water flows southward toward the river and toward the Riley well. Plate 5 illustrates the part of the zone of contribution that is closest to the wells and shows the downgradient, southernmost limit of the zone of contribution in the river valley.

The remaining part of the zone of contribution is that area of the Aberjona River drainage basin upgradient and outside of the area of influence of wells $G$ and $H$. A small amount of the surface water in the river entering the northern end of the study area, which is derived from ground-water discharge and surface-water runoff in the upgradient drainage area, is induced from the river to the wells under pumping conditions. The importance of including this area in the zone of contribution of wells $\mathrm{G}$ and $\mathrm{H}$ is to emphasize that the quality of water pumped by the wells is affected by the quality of both the ground water in the vicinity and the stream water flowing past the wells. Figure 6 is an expanded view of the subbasin of the Aberjona River showing the entire zone of contribution of wells $G$ and $H$. As illustrated on figure 6 , the zone of contribution of the wells comprises approximately 75 percent of the subbasin drainage area.

In the vicinity of wells $\mathrm{G}$ and $\mathrm{H}$ (pl. 5), beginning on the eastern side of the study area, the downgradient limit of the zone of contribution crosses Washington Street 600 feet south of Salem Street and proceeds southwestward to the Aberjona River. The exact location of this line is unknown because of lack of field data; however, the location of the line is estimated as a ground-waterflow line that crosses the known water-table contours at a right angle and extends upgradient to the ground-water divide located northeast of the study area. From the point where the line meets the Aberjona River, the downgradient limit of the 
Subbasin drainage area of the Aberjona River that comprises the zone of contribution to wells $G$ and $H$

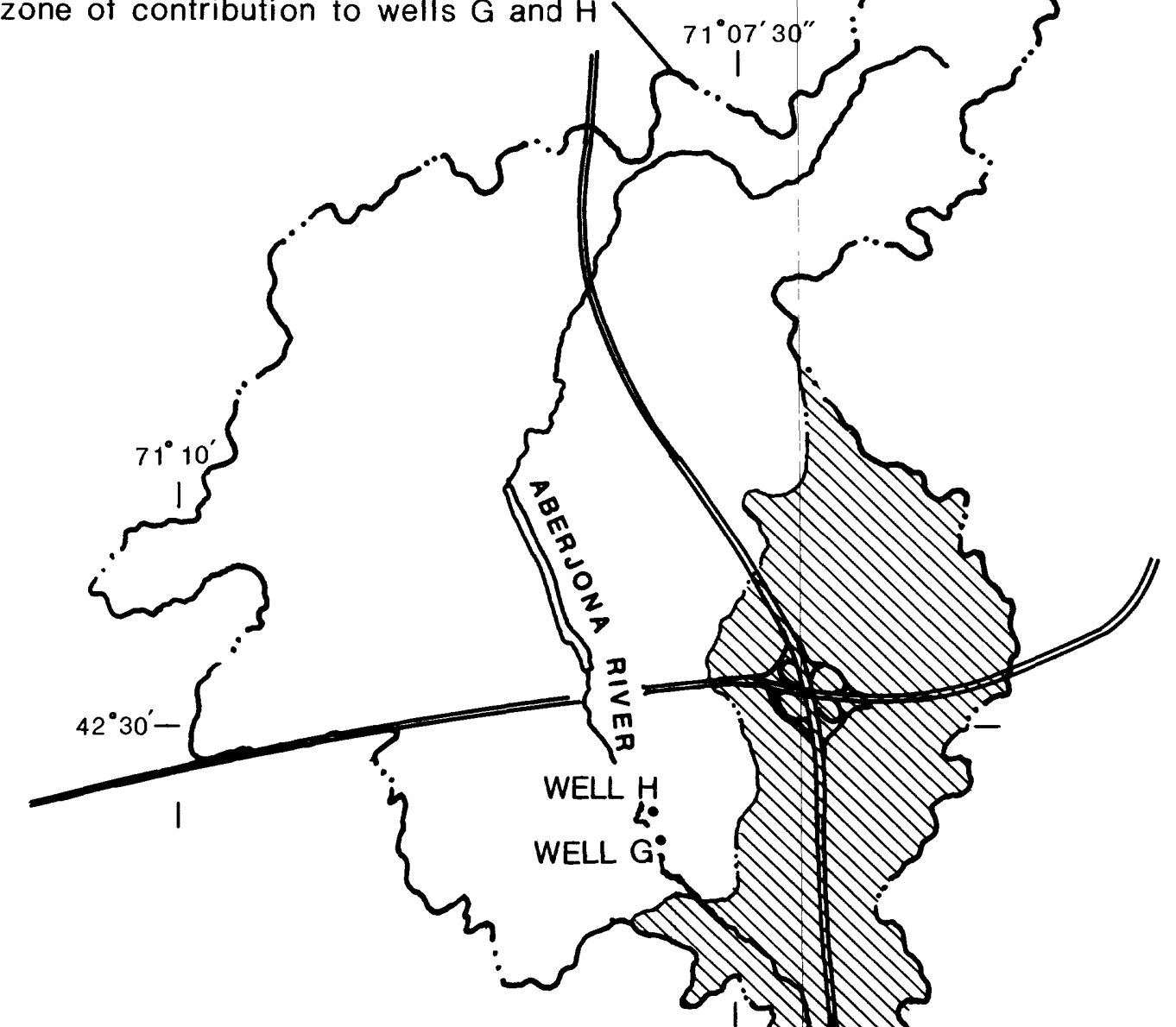

Downgradient subbasin drainage area of the Aberjona River, outside the zone of contribution of wells $\mathrm{G}$ and $\mathrm{H}$

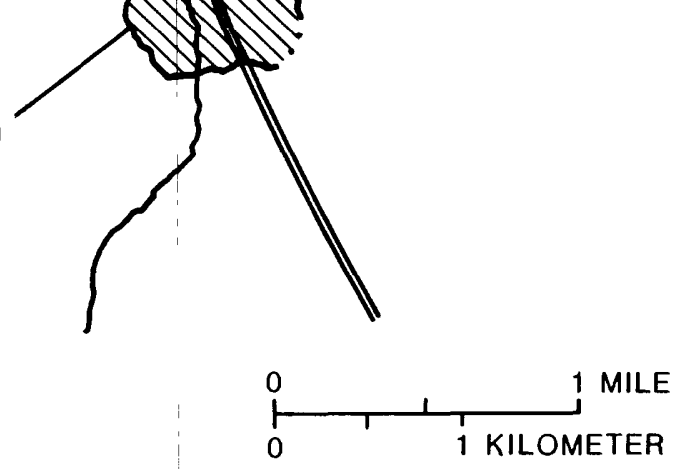

Figure 6.--Subbasin drainage area of the Aberjona River comprising the zone of contribution to wells $G$ and $H$. 
zone of contribution crosses the river, turns northwestward, and follows the channel of the Aberjona River to the vicinity of well site S96. This area marks the location of a local ground-water divide between wells $\mathrm{G}$ and $\mathrm{H}$ and the Riley well. Between well sites $\mathrm{W}_{13}$ and $\mathrm{W} 14$, the line turns westward, crosses the remainder of the wetland on the western side of the river valley, and proceeds northwestward toward the subbasin drainage divide west of the study area.

The position of the downgradient limit of the zone of contribution drawn on plate 5 represents an average location for the entire thickness of the aquifer. As described earlier, the magnitude and extent of the drawdown impacts caused by the pumping wells is different at different levels of the aquifer. Careful review of all of the observationwell data shows that in comparison to the "average" line drawn on plate 5 , the downgradient limit shifts toward the river when water-table data are used, and that it shifts toward the Riley well when hydraulic-head data from the deepest level of the aquifer are used.

Furthermore, the position of the downgradient limit of the zone of contribution cannot be defined precisely and is not permanently fixed. The size of the area south of wells $\mathrm{G}$ and $\mathrm{H}$ that contributes water to the wells is variable, dependent on hydrologic conditions that control rates of groundwater discharge in the stratified drift, leakage from bedrock, and surface water available for infiltration from the wetland and river. In the area southwest of wells $G$ and $H$, the position of the limit of the zone of contribution is influenced significantly by the on-off pumping cycle of the Riley well. As shown on plate 5 , the edge of the zone of contribution occurs north of the Riley well when it is pumping. When the Riley well is not pumping, it is likely that water-table conditions return to normal in the area and the southernmost limit of the zone of contribution of wells $G$ and $H$ shifts southwestward to include part and perhaps all of the Riley well area.

As shown in figure 6 , the entire area of the zone of contribution to wells $\mathrm{G}$ and $\mathrm{H}$ includes: (1) The stratified-drift aquifer beneath the lowland on the eastern side of the wells, beneath the wetland north, south, and west of the wells east of the river, and beneath a portion of the wetland on the western side of the river; (2) the area of stratified drift, till, and bedrock northeast of wells $G$ and $H$ upgradient from the local ground-water divide northeast of Washington Street; and (3) the remaining upgradient surface- and ground-water drainage to the watershed divide east, north, and west of wells $\mathrm{G}$ and $\mathrm{H}$ in the Aberjona River.

Finally, the zone of contribution of wells G and $\mathrm{H}$ illustrated on plate 5 and in figure 6 also may be identified in terms of the zoned approach to public ground-water-supply protection under the Massachusetts ALA (Aquifer Land Acquisition) program defined in Chapters 286 and 723 of 1985 Massachusetts legislation. According to the ALA definition, the area of land described in (1) above within a 400-foot radius of wells $G$ and $H$ corresponds to "Zone I". The area of stratified drift described in (2) corresponds to "Zone II"; similarly, the area in (3) corresponds to "Zone II". If the process of determining areas that are most affected by pumping wells $\mathrm{G}$ and $\mathrm{H}$ includes consideration of the actual distances and depths at which significant effects will occur, results of the 30-day aquifer test indicate that the land area most affected includes the wetland on both the eastern and western sides of the Aberjona River upriver and downriver from the wells ("Zone I"), and the upland area east and north of the wells ("Zone II").

\section{SUMMARY AND CONCLUSIONS}

Ground-water contamination by chlorinated volatile organic compounds detected by the MDEQE in 1979 forced the closing of wells G and $\mathrm{H}$, public-supply wells in the City of Woburn, Massachusetts. A 30-day aquifer test was conducted to determine the hydraulic properties of the stratified-drift aquifer in the vicinity of the wells and to determine the area of influence and zone of contribution to wells $\mathrm{G}$ and $\mathrm{H}$ under pumping conditions. The estimated transmissivity of the aquifer in the vicinity of well $G$ is $29,700 \mathrm{ft}^{2} / \mathrm{d}$, with a storage coefficient of 0.20 . The average horizontal hydraulic conductivity in the vicinity of the well ranges between 125 and $350 \mathrm{ft} / \mathrm{d}$. The estimated transmissivity of the aquifer at well $\mathbf{H}$ is $17,600 \mathrm{ft}^{2} / \mathrm{d}$, with a storage coefficient of 0.16 . The average horizontal hydraulic conductivity ranges from 130 to $215 \mathrm{ft} / \mathrm{d}$.

The area of influence after 30 days of pumping well $\mathrm{G}$ at $700 \mathrm{gal} / \mathrm{min}$ and well $\mathrm{H}$ at $400 \mathrm{gal} /$ min is oblong in shape and approximately $3,000 \mathrm{ft}$ long and 1,700 $\mathrm{ft}$ wide, as measured at the midpoint between wells $G$ and $H$, and comprises an area in which drawdown exceeds $1 \mathrm{ft}$. The area of influence extends from approximately $1,100 \mathrm{ft}$ north of well $\mathrm{H}$ to $1,200 \mathrm{ft}$ south of well $\mathrm{G}$. In the lower stratified-drift aquifer in which wells $G$ and 
$\mathrm{H}$ are finished, the shape of the area of influence is similar to that observed in the upper stratifieddrift aquifer; however, the size of the area is much greater than that in the upper stratified-drift aquifer.

The shape and size of the area of influence of wells $G$ and $H$ in the upper stratified drift are caused primarily by three factors: (1) The two pumping wells are located on a north-south axis that elongates the cone of depression around the wells; (2) the Aberjona River to the west flows along a course more or less parallel to the wells and is a source of water to the aquifer under pumping conditions; and (3) a steep hillslope east of the wells marks the location of a steep, westfacing, near-surface bedrock boundary, which has a significant effect on the amount of ground-water flow on this side of the valley. The boundary effectively minimizes drawdowns caused by the pumping wells east of its location but contributes to relatively large drawdowns between the wells and the side of the valley. The area of influence of wells $G$ and $\mathrm{H}$ described in this report is considered to be a "snapshot" representative of an average area of influence.

Wells $\mathrm{G}$ and $\mathrm{H}$ obtain water from an area of aquifer, or zone of contribution, that may be divided into two parts. Most water pumped by the wells is obtained from that part of the aquifer immediately surrounding both wells and from induced infiltration of surface water from the overlying river and wetland. Water also is obtained from a small area south of the wells, and a limit can be determined which marks the dividing line between the area in which ground water flows toward well G and the area in which ground water flows southward toward the river and toward the Riley well. The remaining part of the zone of contribution is that area of the Aberjona River drainage basin upgradient from and outside of the area of influence of wells $G$ and $H$. A small amount of surface water in the river entering the northern end of the study area, which is derived from ground-water discharge and surface-water runoff in the upgradient drainage area, is induced from the river to the wells under pumping conditions.

The position of the downgradient limit of the zone of contribution cannot be defined precisely and is not permanently fixed. The size of the area south of wells $G$ and $H$ that contributes water to the wells is variable and depends on the pumping rates of wells $G$ and $H$, on the rate and schedule of pumping of the Riley well, and on hydrologic conditions.

\section{SELECTED REFERENCES}

Castle, R. O., 1959, Surficial geology of the Wilmington quadrangle Massachusetts: U.S. Geological Survey Geologic Quadrangle map GQ-122.

Delaney, D. F., and Gay, F. B., 1980, Hydrology and water resources of the coastal drainage basins of northeastern Massachusetts, from Castle Neck River, Ipswich, to Mystic River, Boston: U.S. Geological Survey Hydrologic Investigations Atlas HA-589, 3 pl., scale $1: 48,000$.

Haeni, F. P., 1986, Application of seismic refraction methods in groundwater modeling studies in New England: Geophysics, v. 51, no. 2, pp 236-249.

Kaye, C. A., 1980, Bedrock geologic maps of the Boston North, Boston South, and Newton quadrangles, Massachusetts: U.S. Geological Survey Miscellaneous Field Studies Maps MF1241, scale, 1:24,000 [1981].

LaForge, Lawrence, 1932, Geology of the Boston area Massachusetts: U.S. Geological Survey Bulletin 839, 105 p.

Lohman, S. W., 1972, Ground-water hydraulics: U.S. Geological Survey Professional Paper 708, $70 \mathrm{p}$.

McDonald, M. G., and Harbaugh, A. W., 1984, A modular three-dimensional finite-difference ground-water flow model: U.S. Geological Survey Open-File Report 83-875, 528 p.

Pakiser, L .C., and Black, R. A, 1957, Exploring for ancient channels with the refraction seismograph: Geophysics, v. 22, pp 32-47.

Rantz, S. E., and others, 1982, Measurement and computation of streamflow: volume 1, Measurement of stage and discharge: U.S. Geological Survey Water-Supply Paper 2175, 284 p.

Scott, J. H., 1977, SIPT-A seismic refraction inverse modeling program for timeshare terminal computer systems: U.S. Geological Survey Open-File Report 77-365, 35 p. 
Scott, J. H., Tibbetts, B. L., and Bordick, R. G., 1972 , Computer analysis of seismic refraction data: U.S. Department of the Interior, Bureau of Mines Report of Investigations RI 7595, 295 p.

Siegel, D. I., and Ericson, D. W., 1980, Hydrology and water quality of the Copper-Nickel area, northeastern Minnesota: U.S. Geological Survey Water-Resources Investigations Report 80-739, 87 p.
Walton, W. C., 1970, Groundwater resource evaluation: New York, McGraw-Hill Book Company, Inc., McGraw-Hill Series in Water Resources and Environmental Engineering, $664 \mathrm{p}$.

Zohdy, A. A. R., Eaton, G. P., and Mabey, D. R., 1974, Application of surface geophysics to ground water investigations: U.S. Geological Survey Techniques of Water-Resources Investigations, book 2, chap. D1, 116 . 


\section{APPENDIX A}

Hydrographs of wells $\mathrm{G}$ and $\mathrm{H}$ during step-drawdown tests 


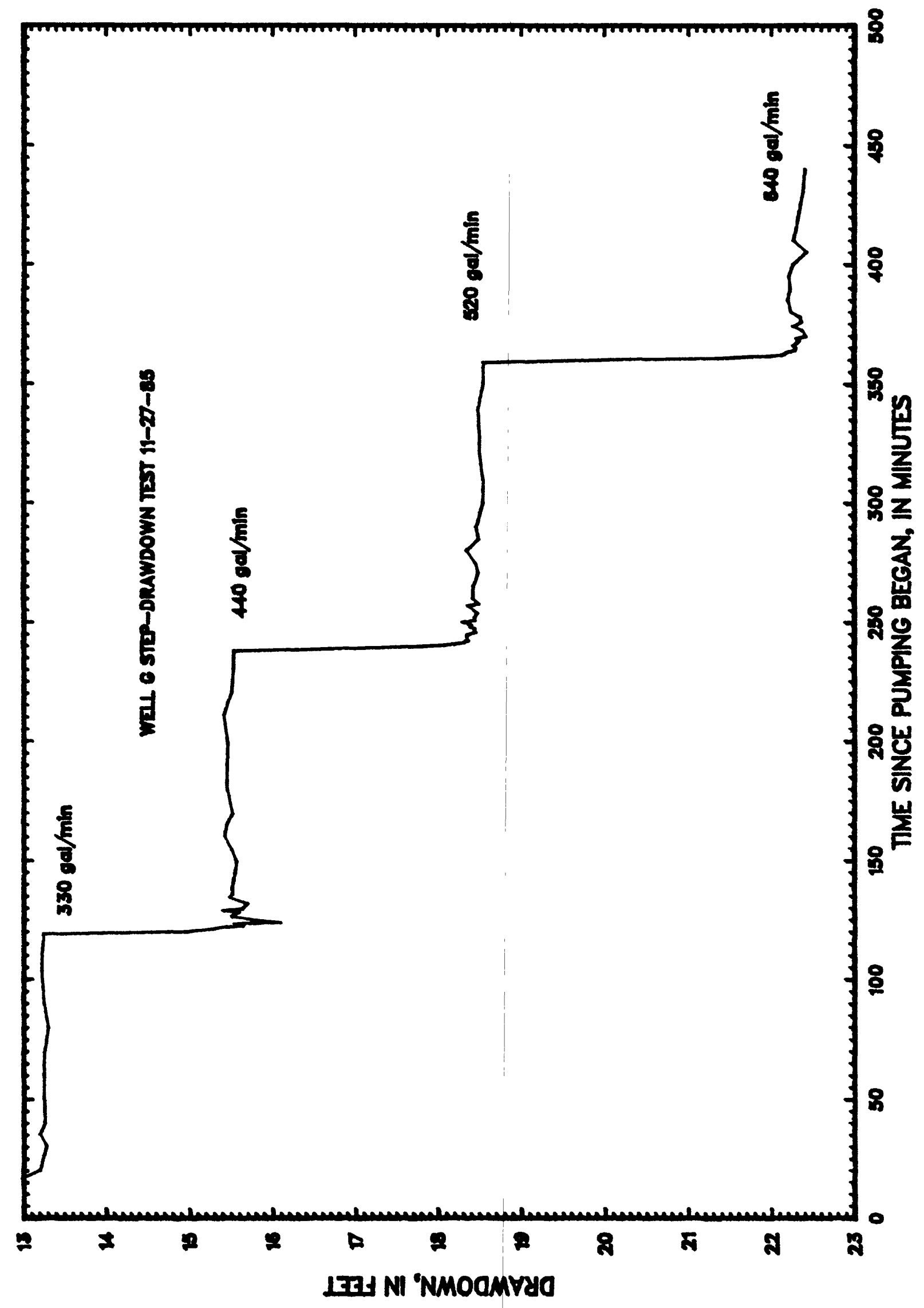




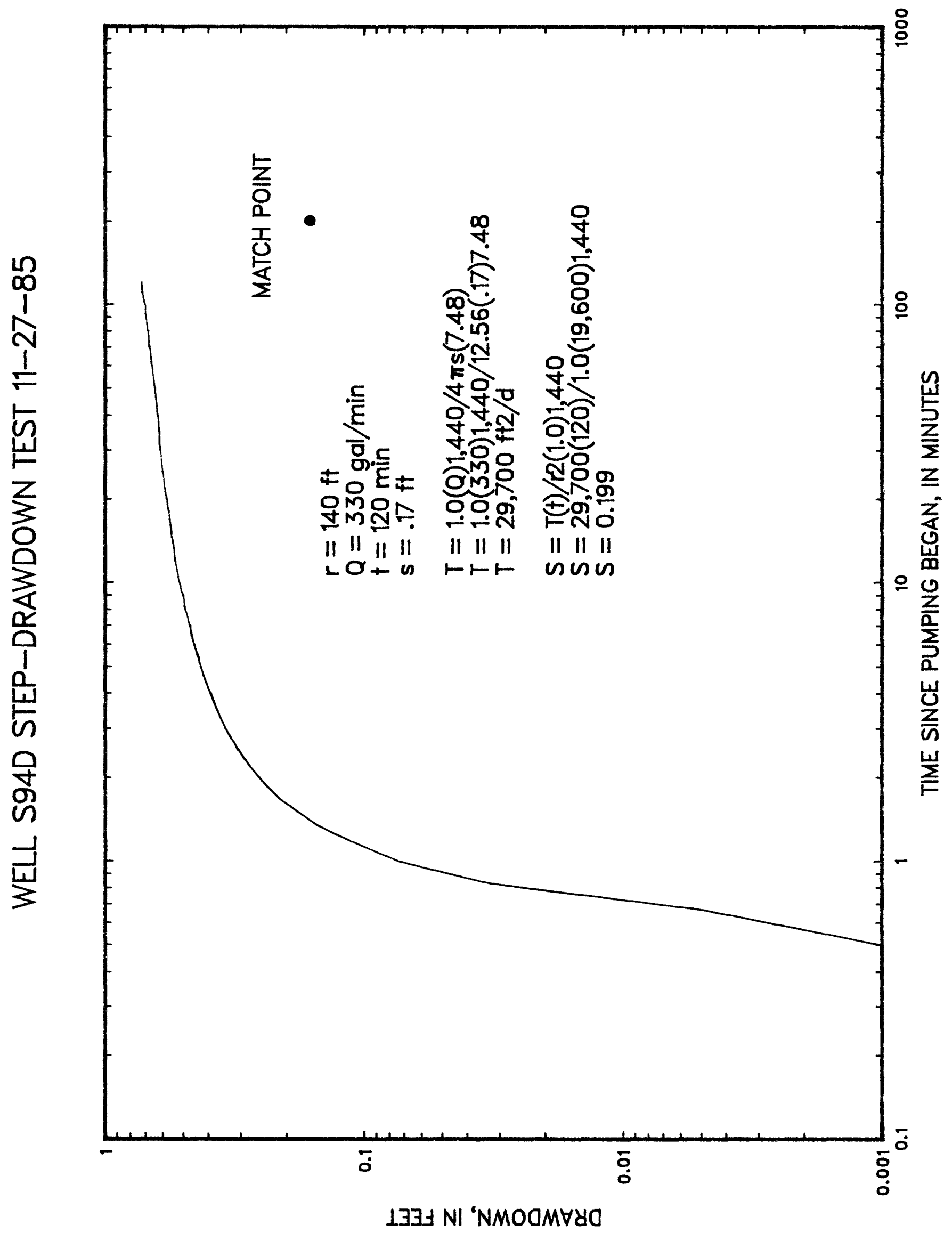




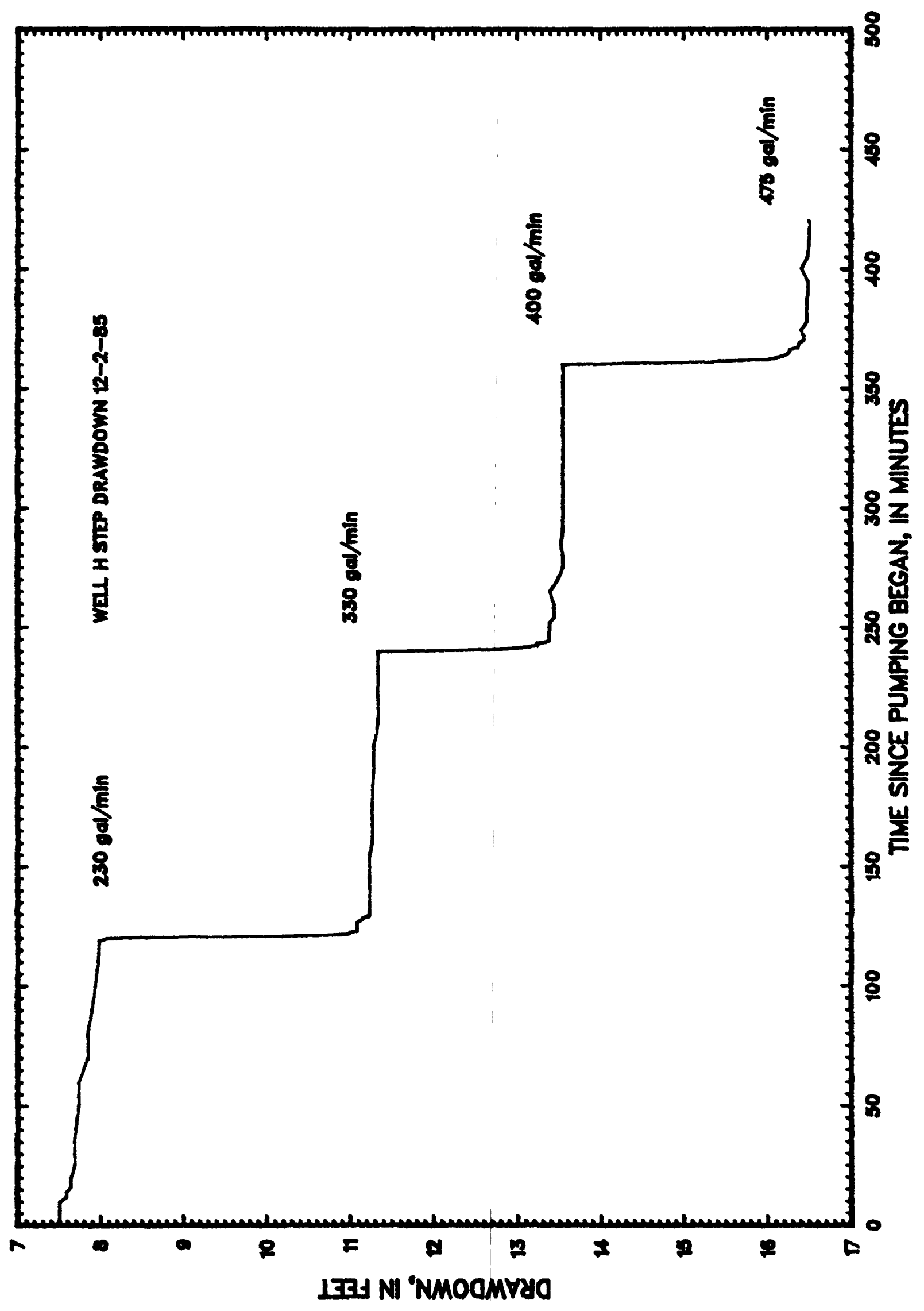




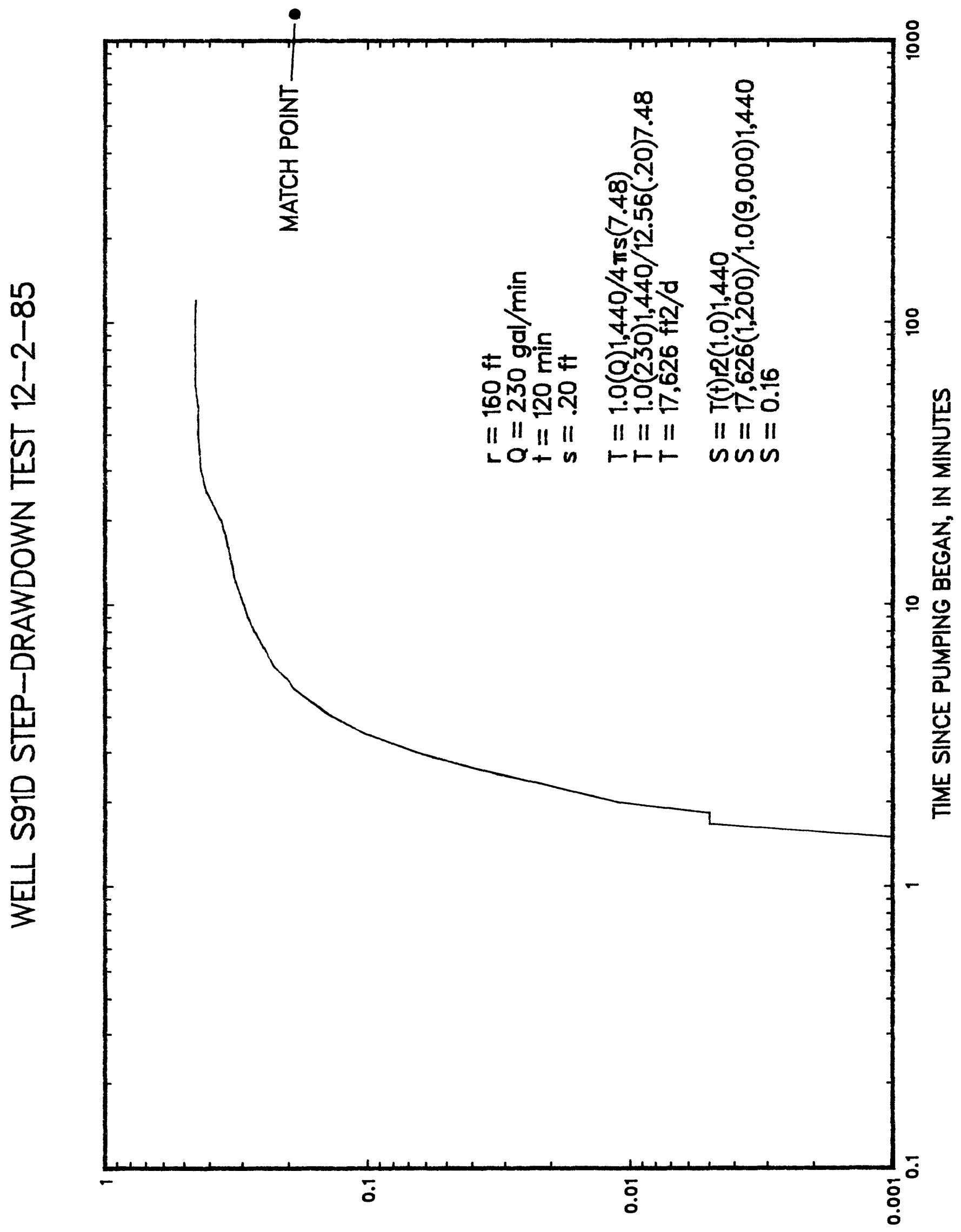

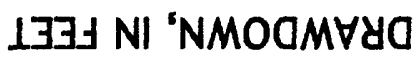




\section{APPENDIX B}

Hydrographs of selected observation wells and piezometers during the 30-day aquifer test, wells $G$ and $H$, December 4, 1985-January 3, 1986 


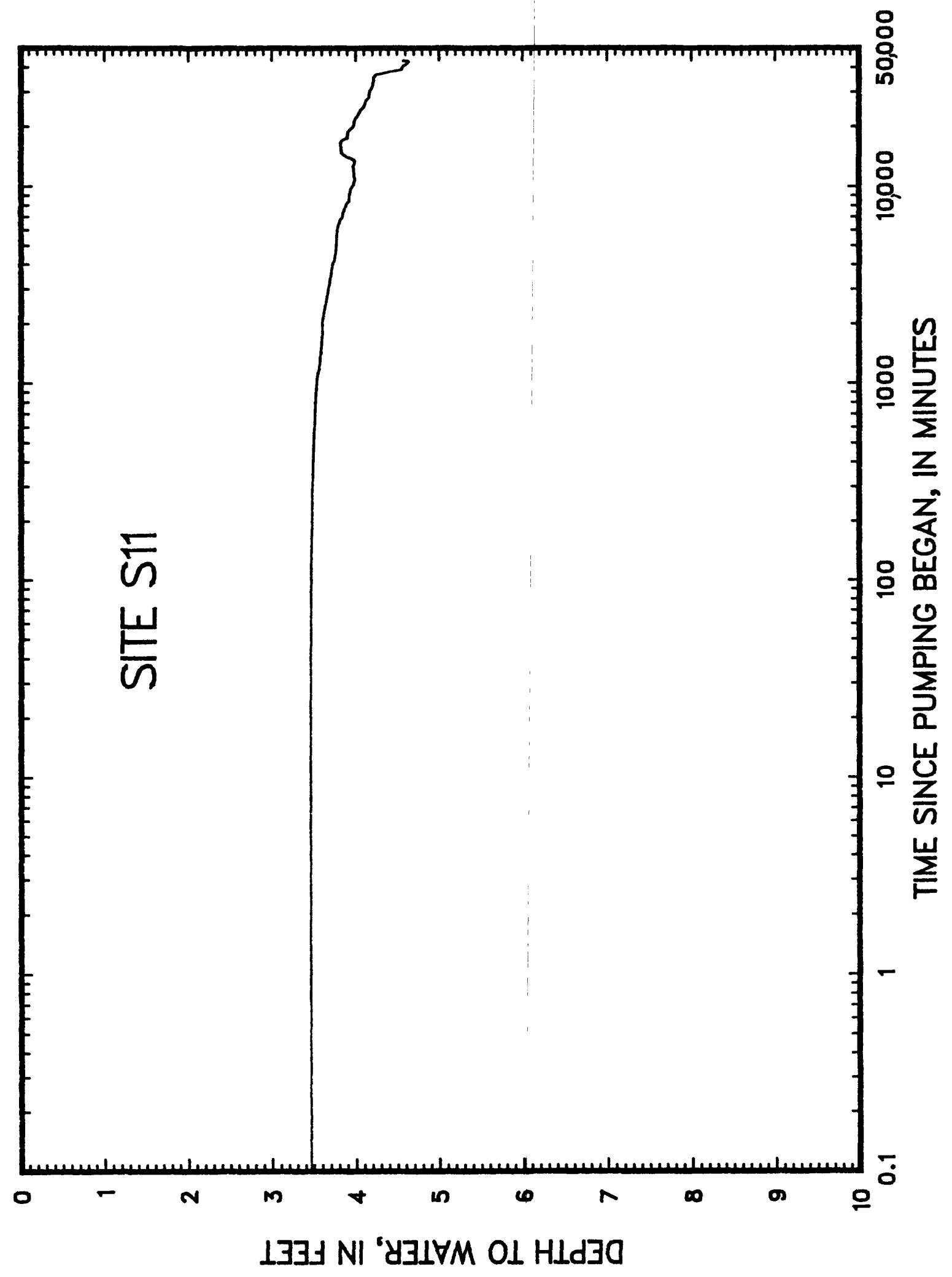

B-2 


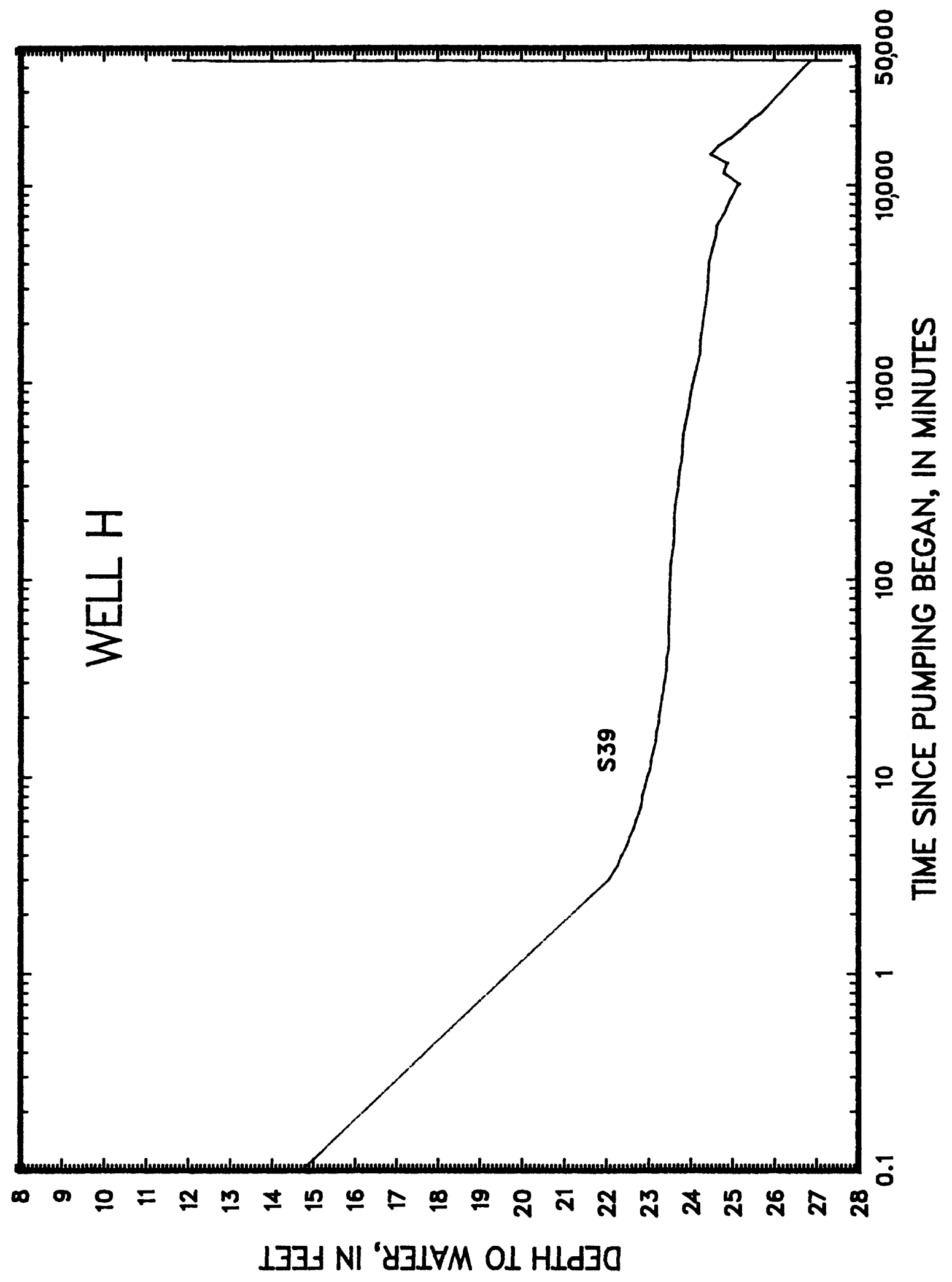

B-3 


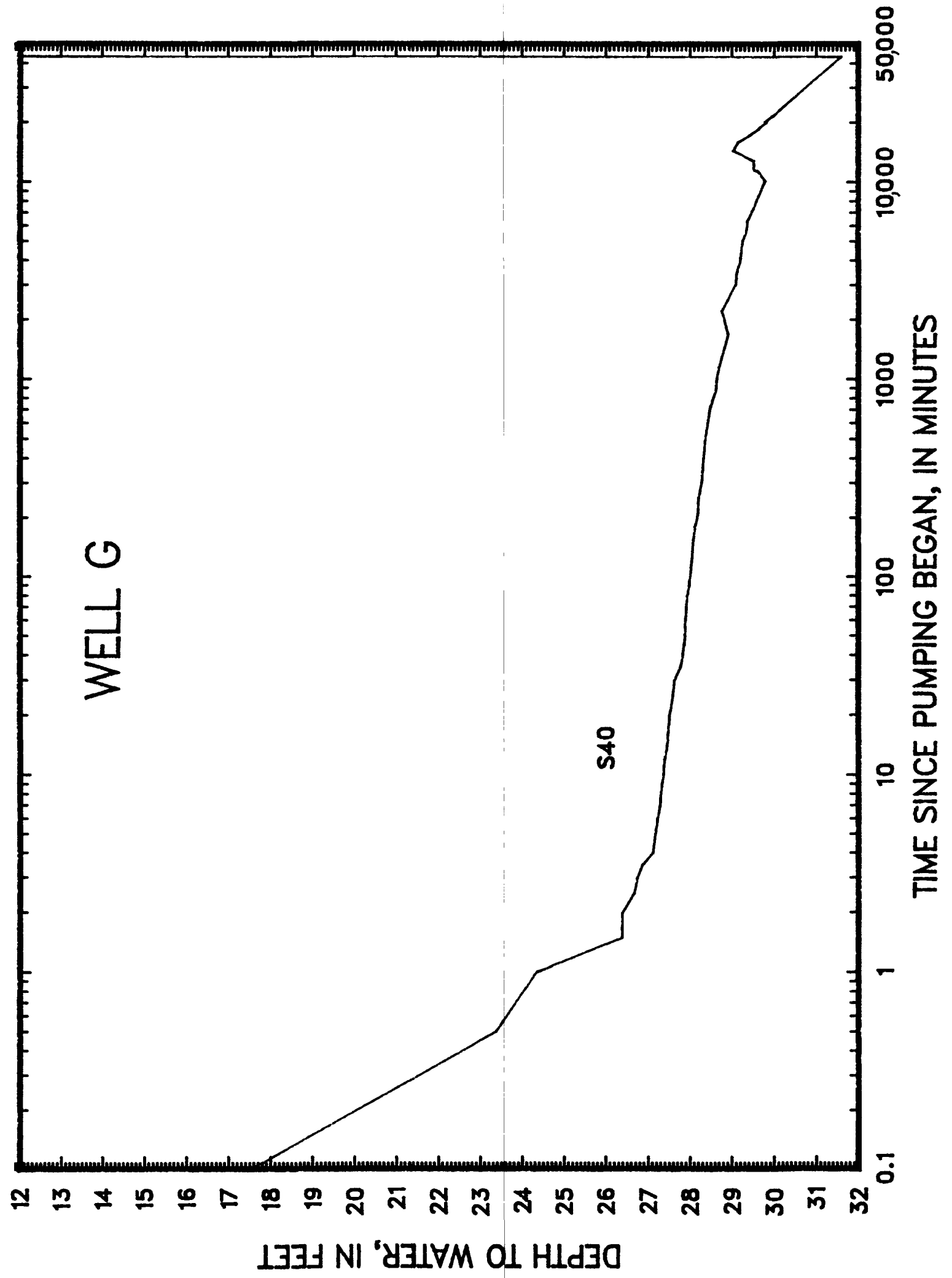




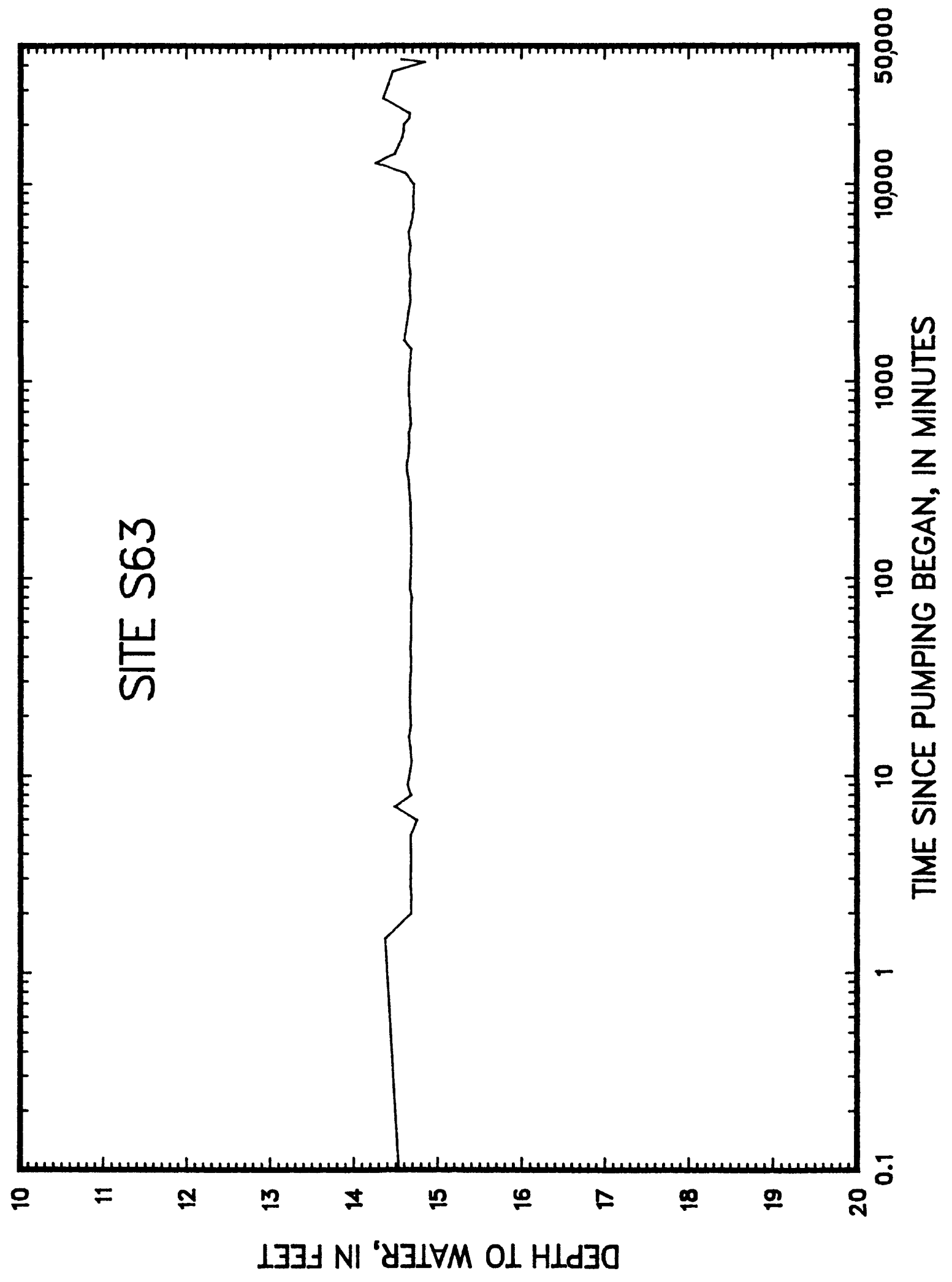

B-5 


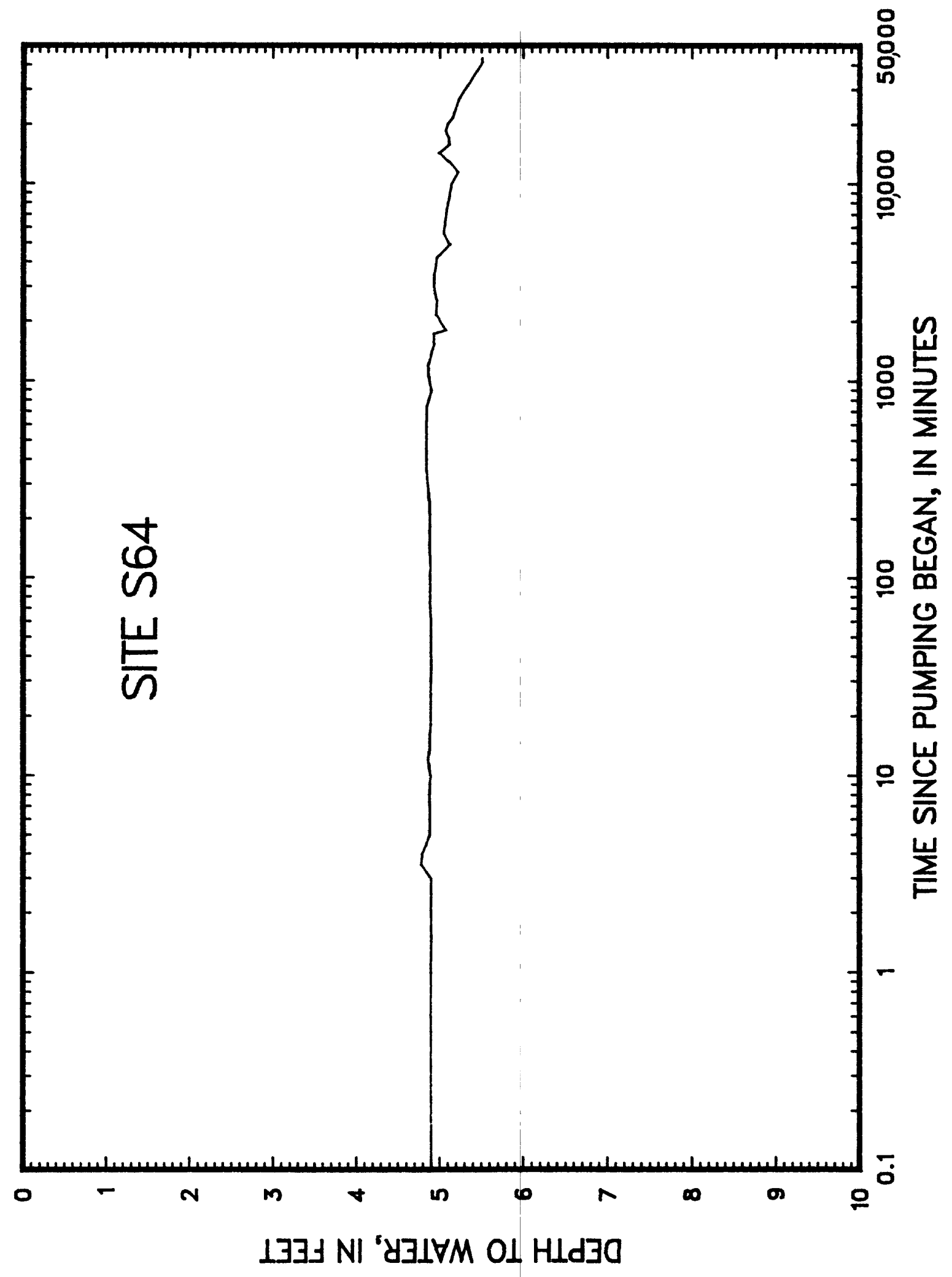

B- 6 


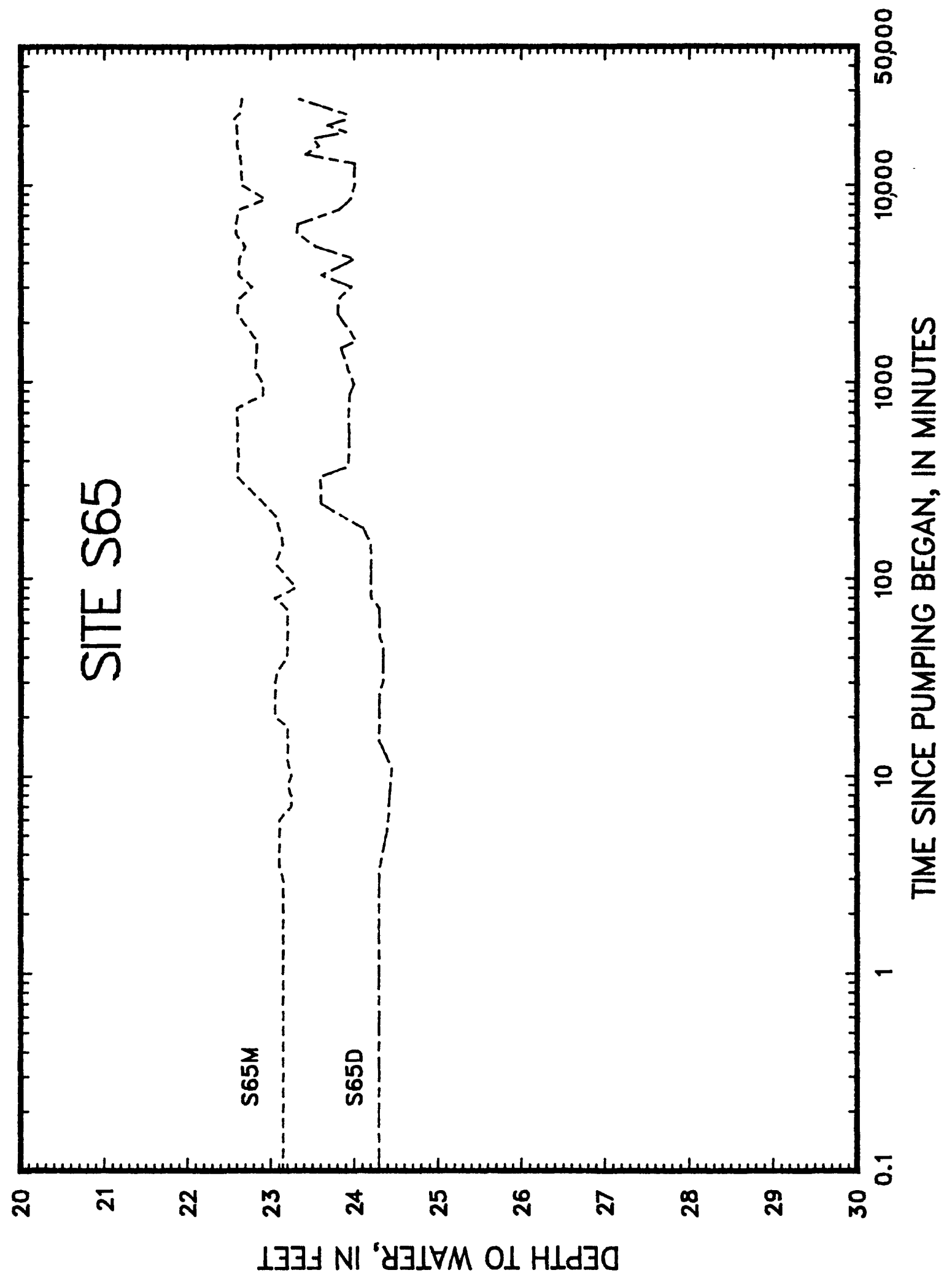

B-7 


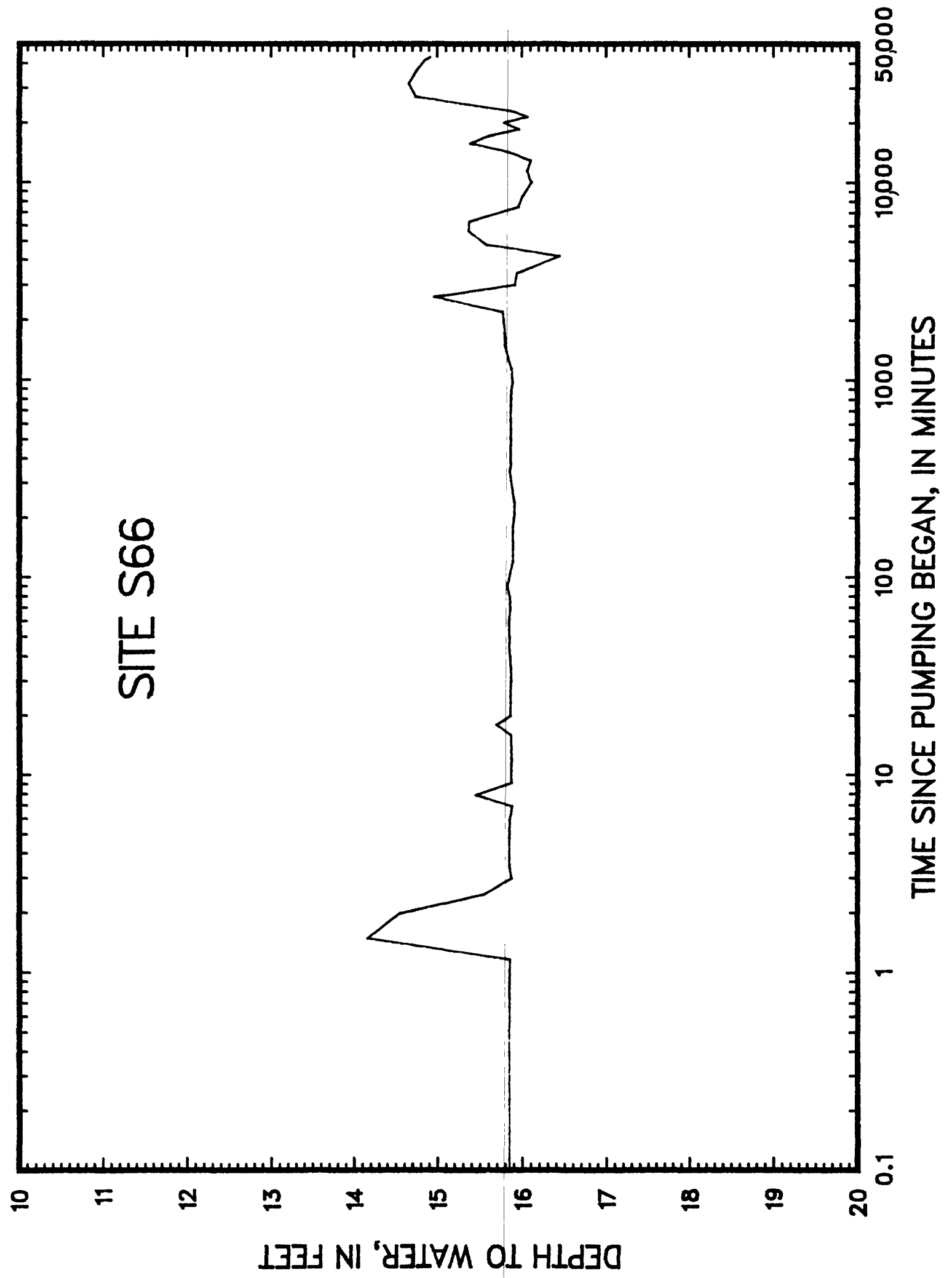




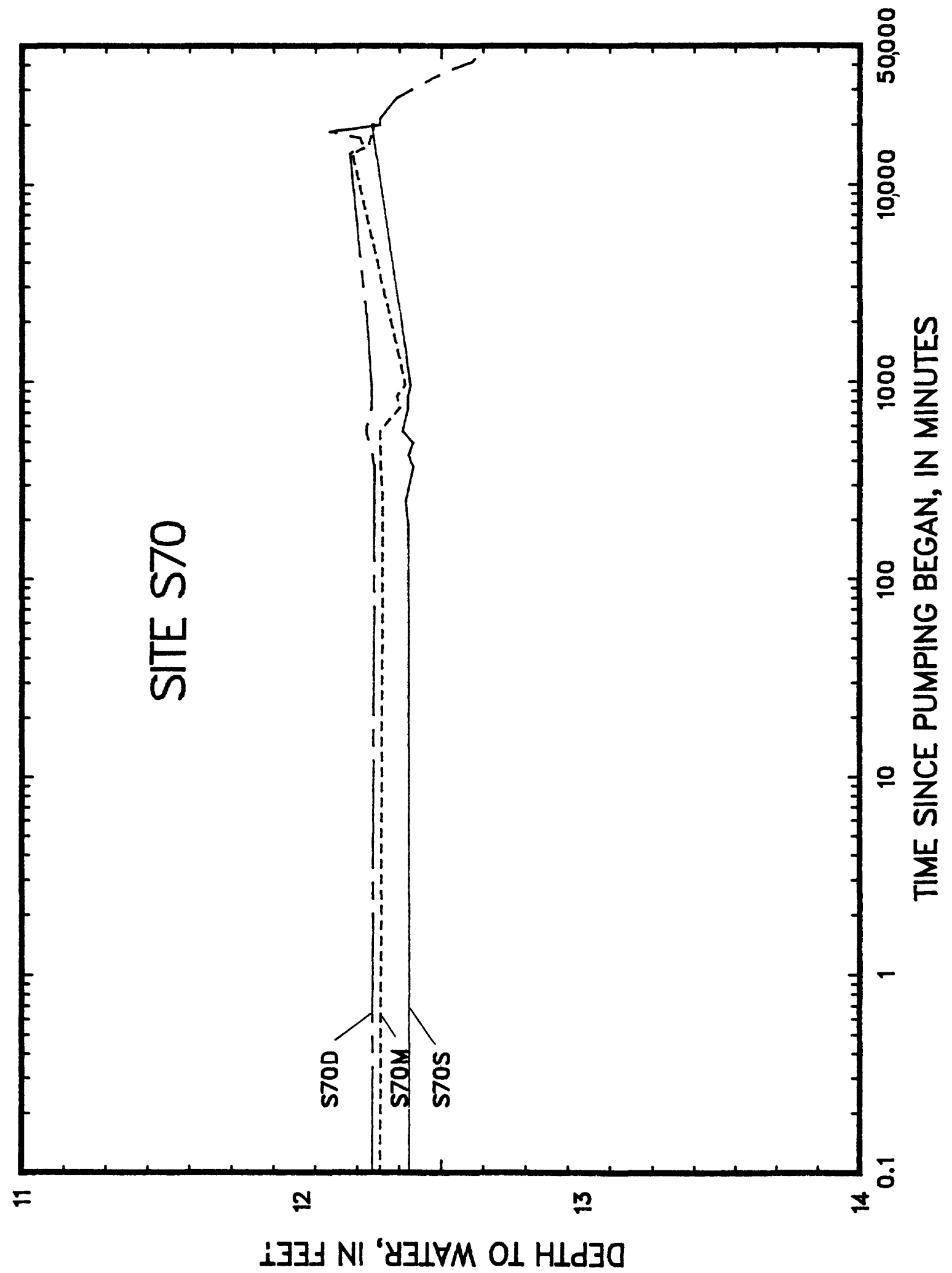




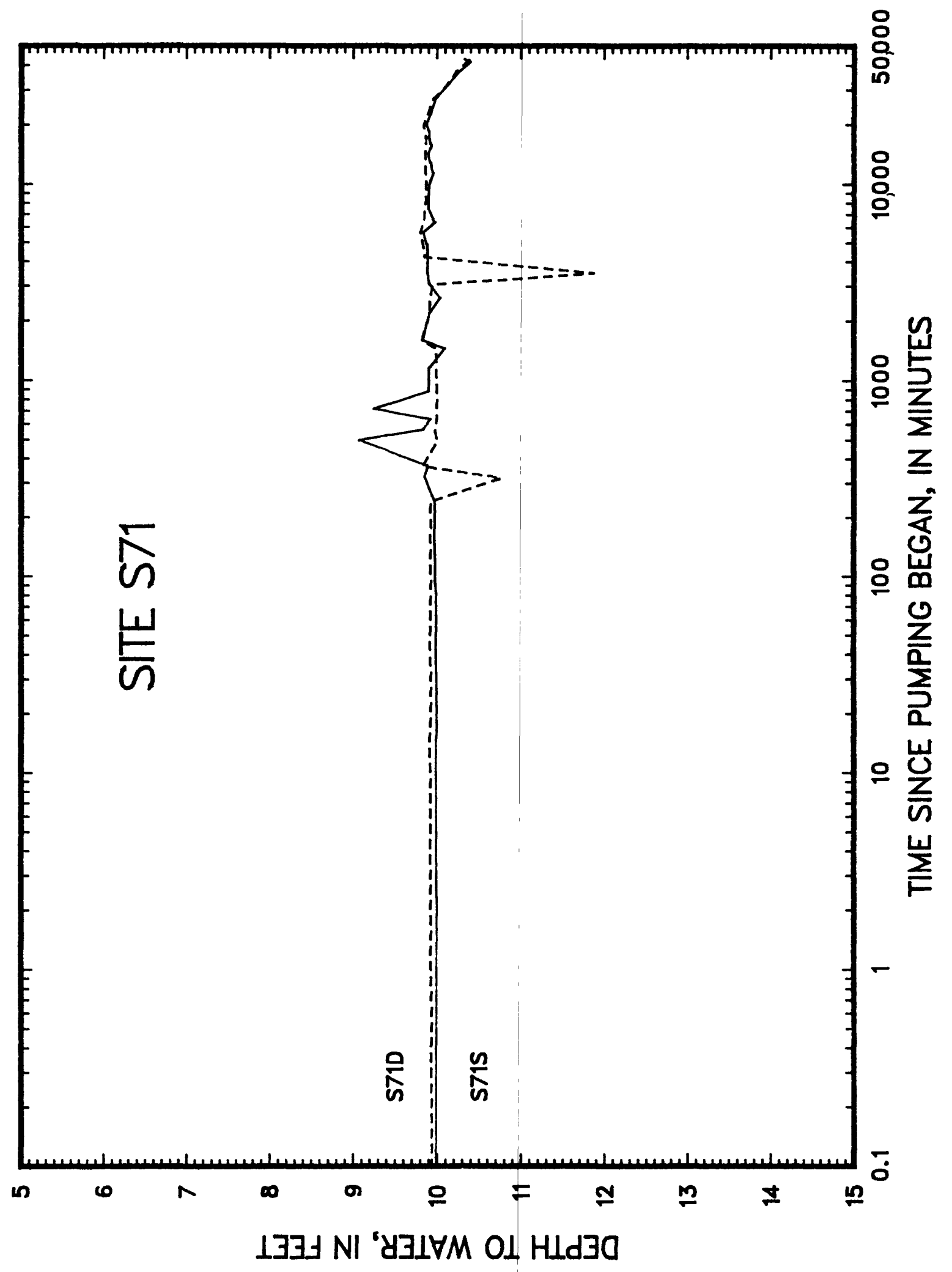

B-10 


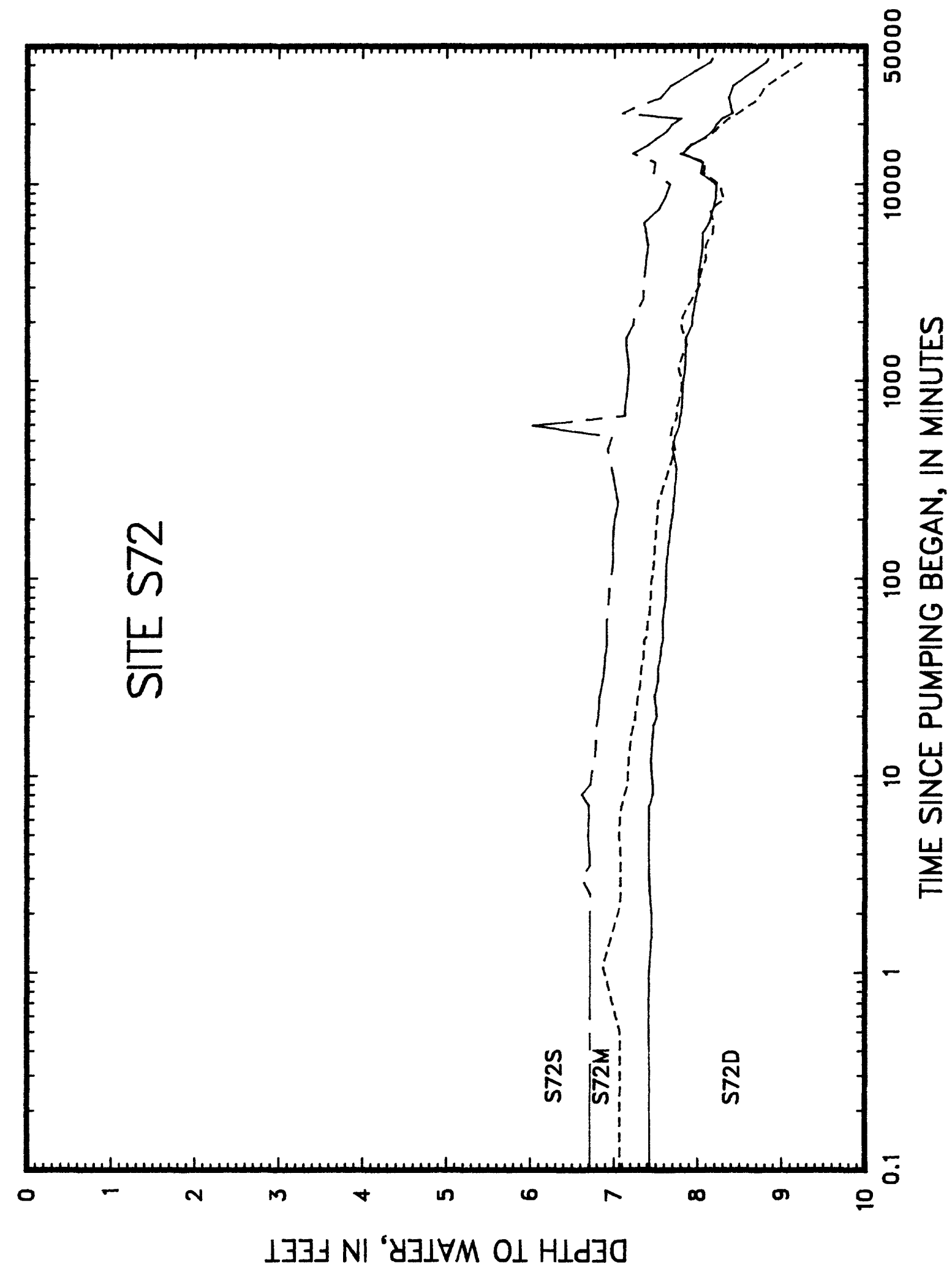

B- 11 


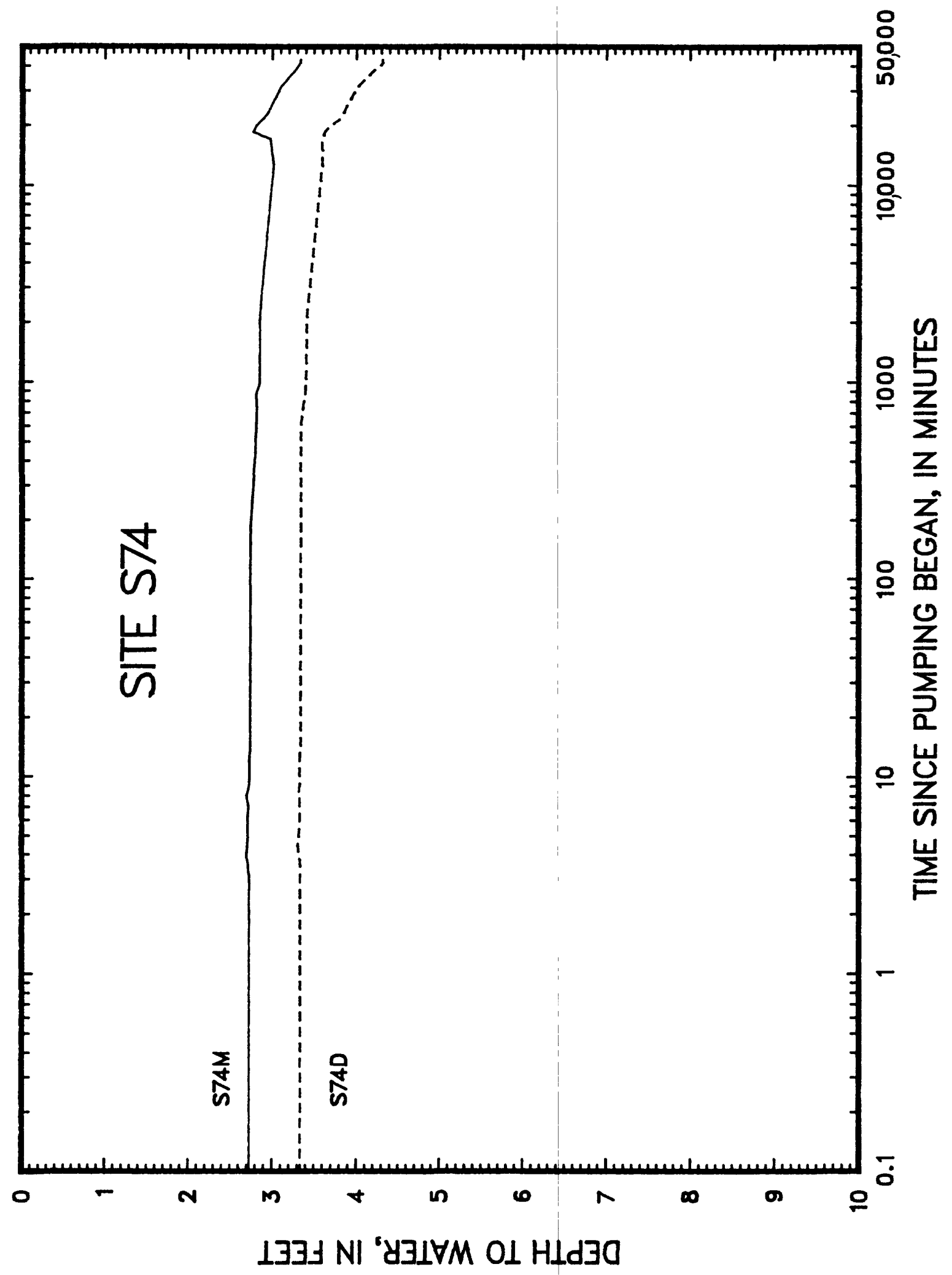

B- 12 


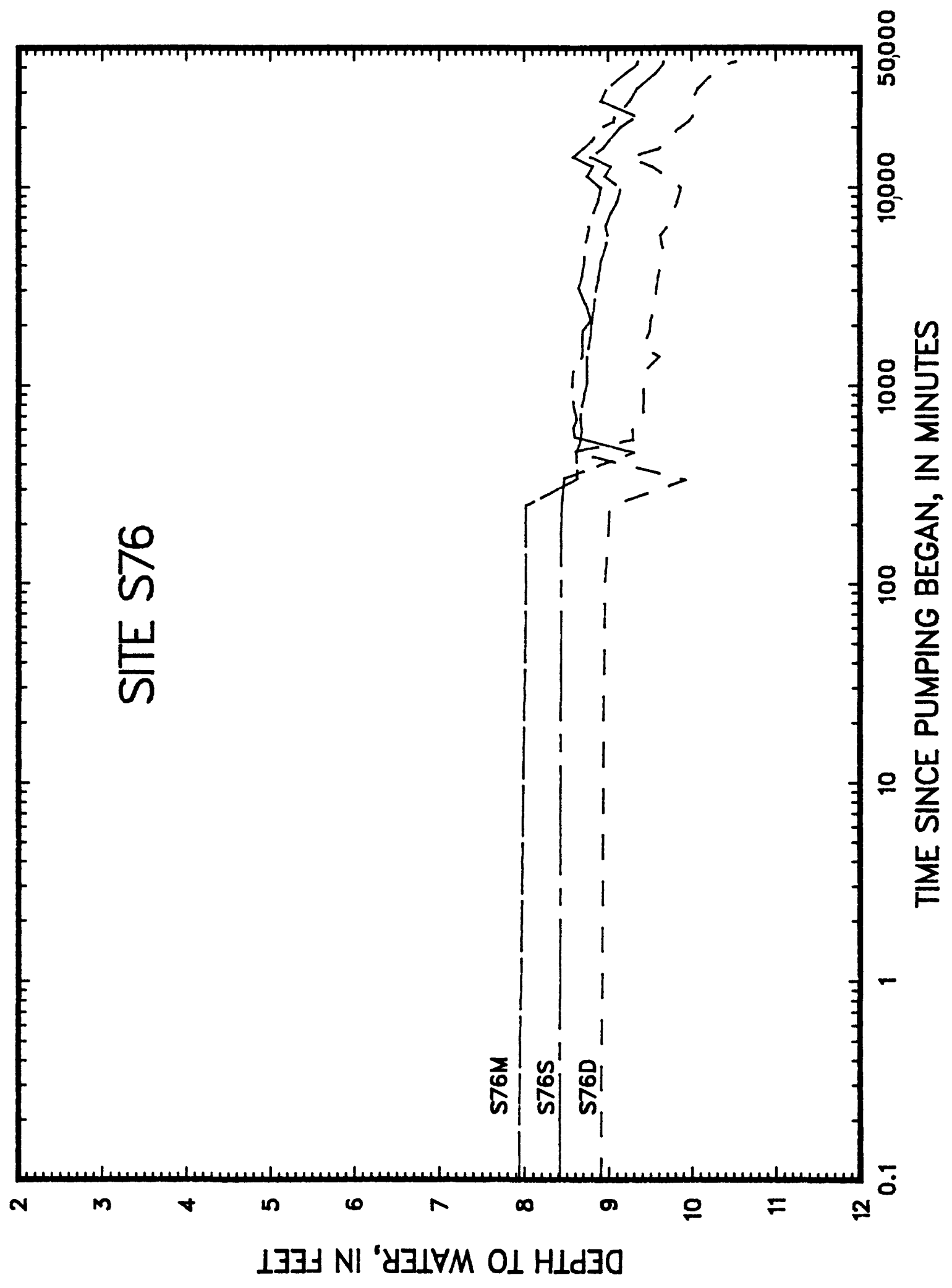

B-1 3 


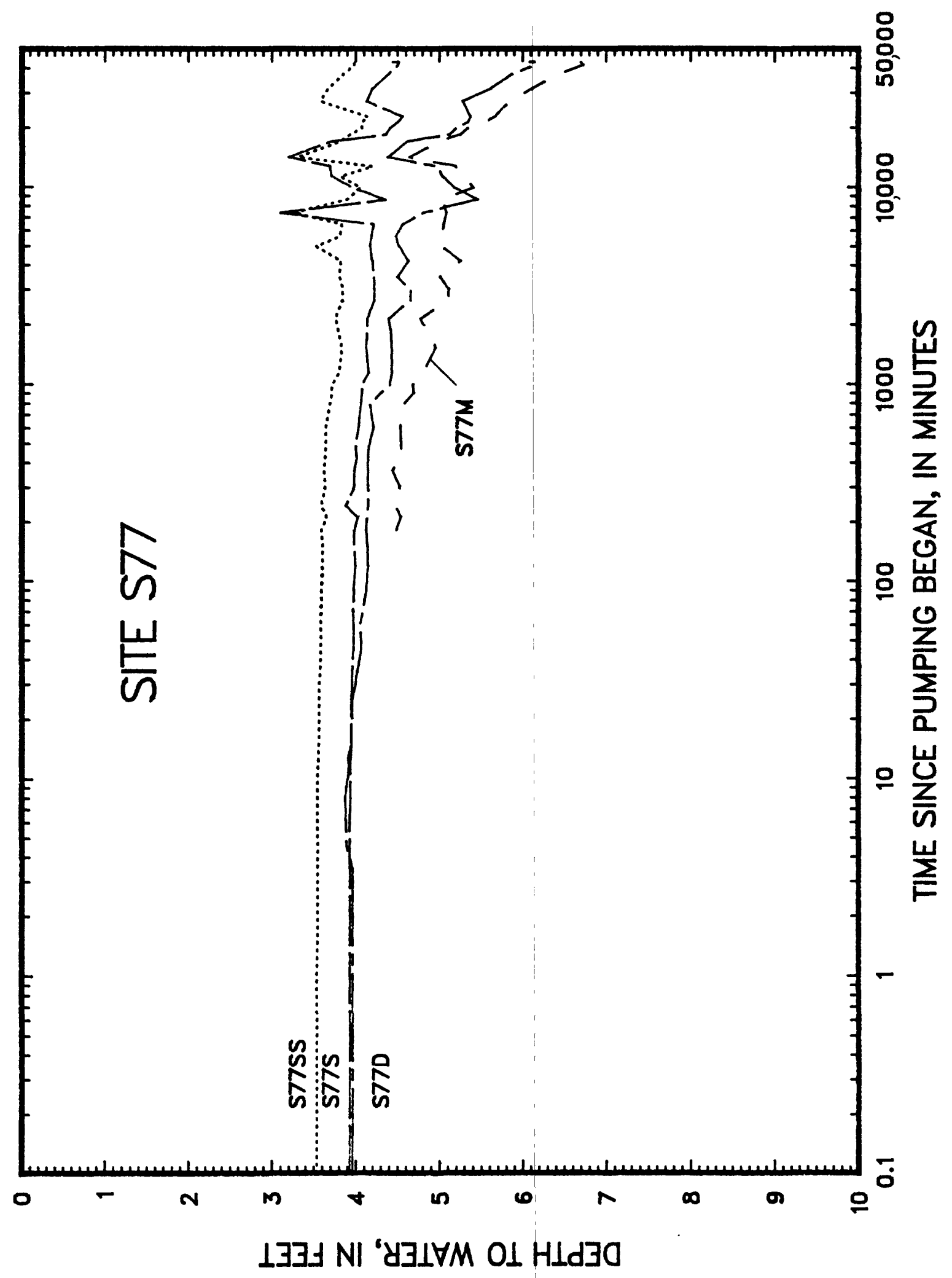

B-14 


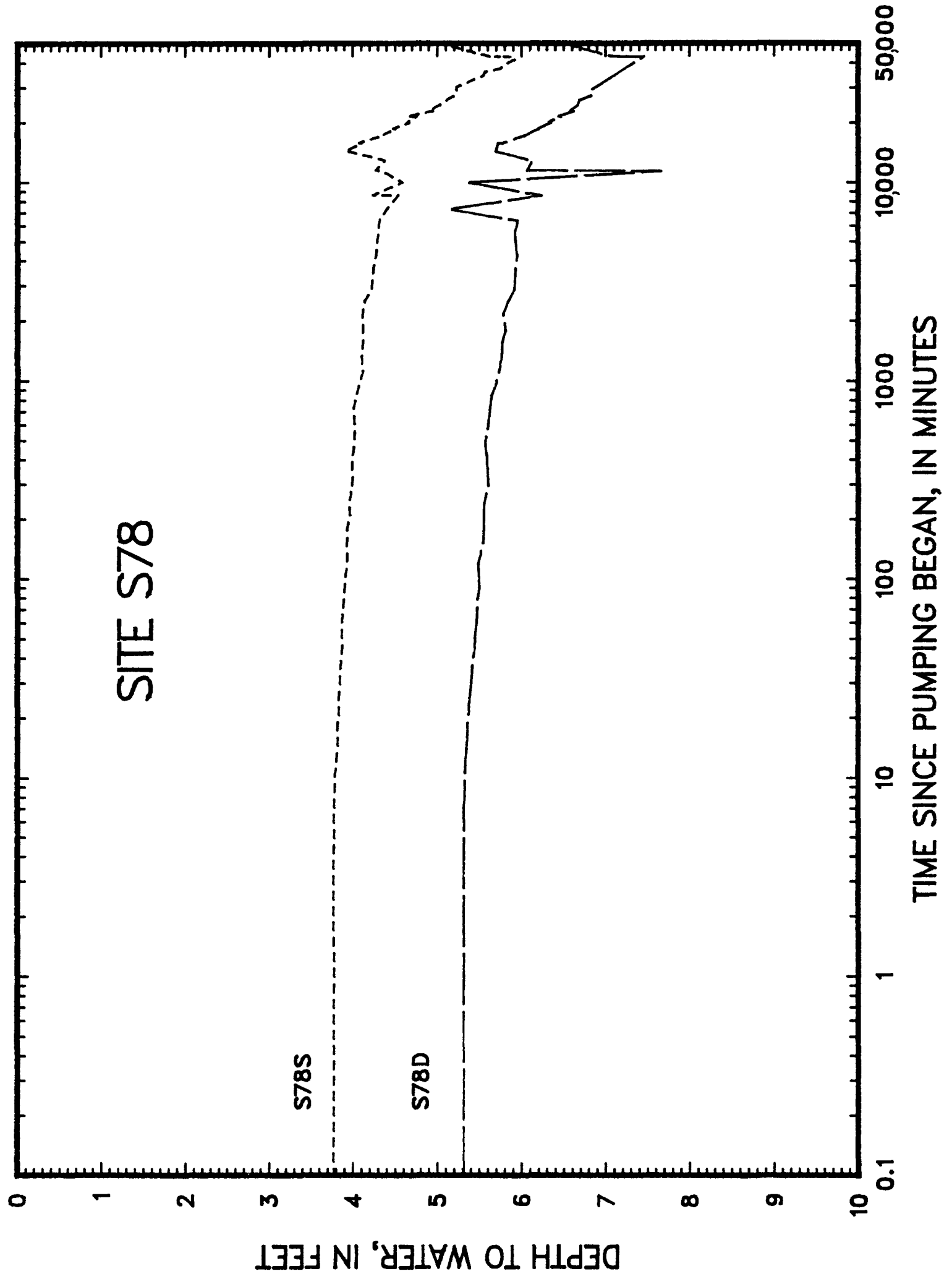

B-1 5 


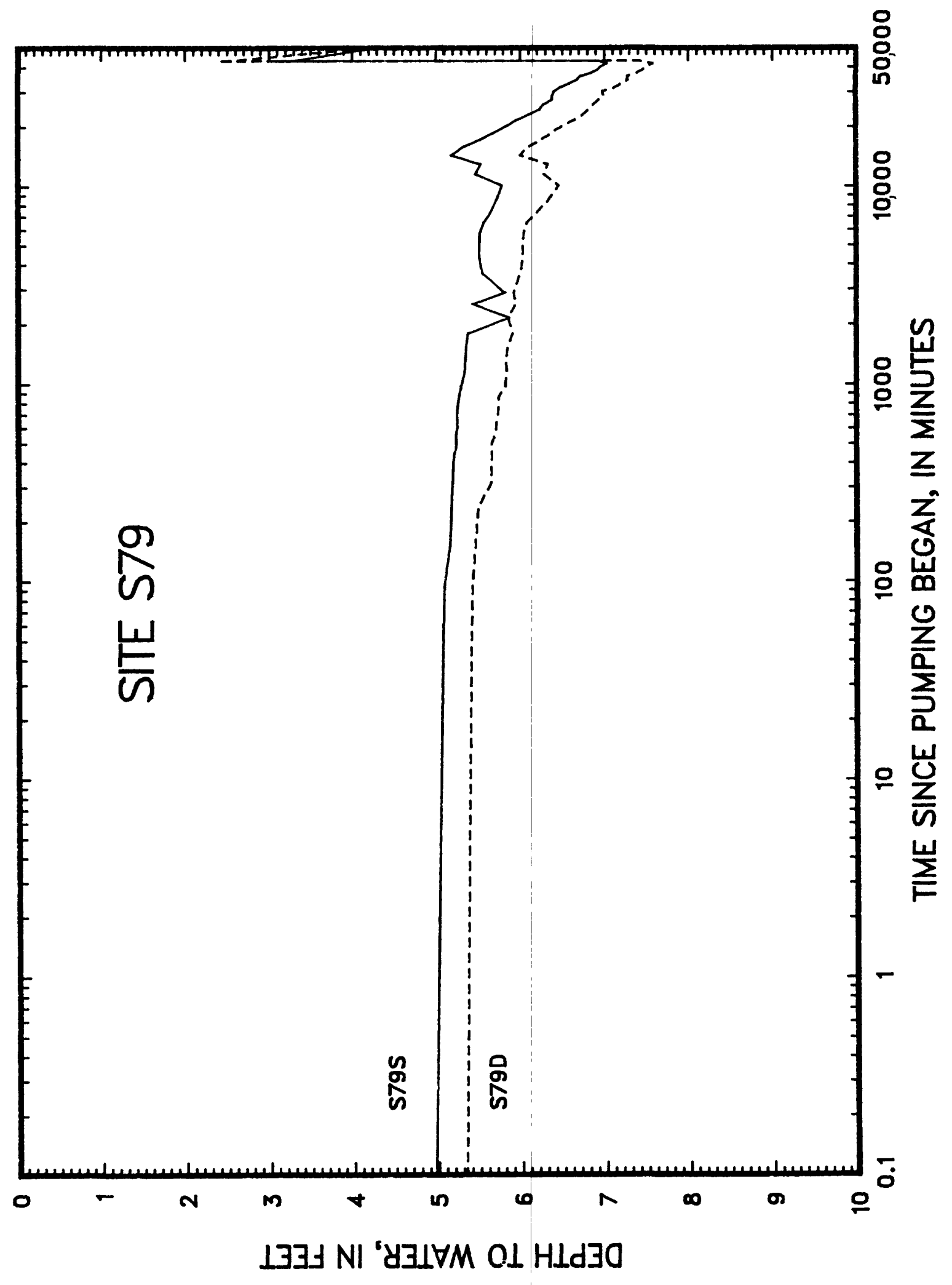

B- 16 


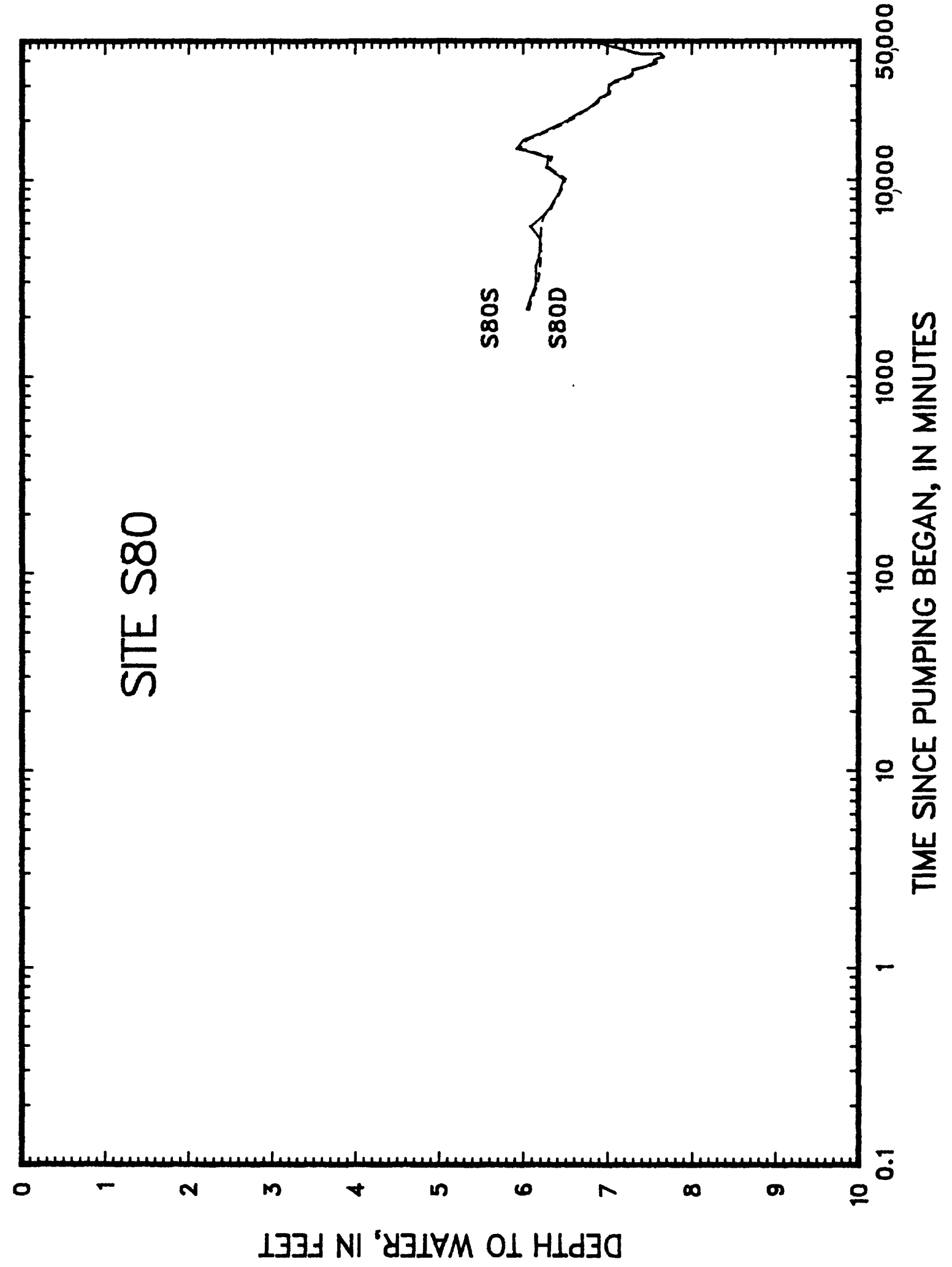

B- 17 


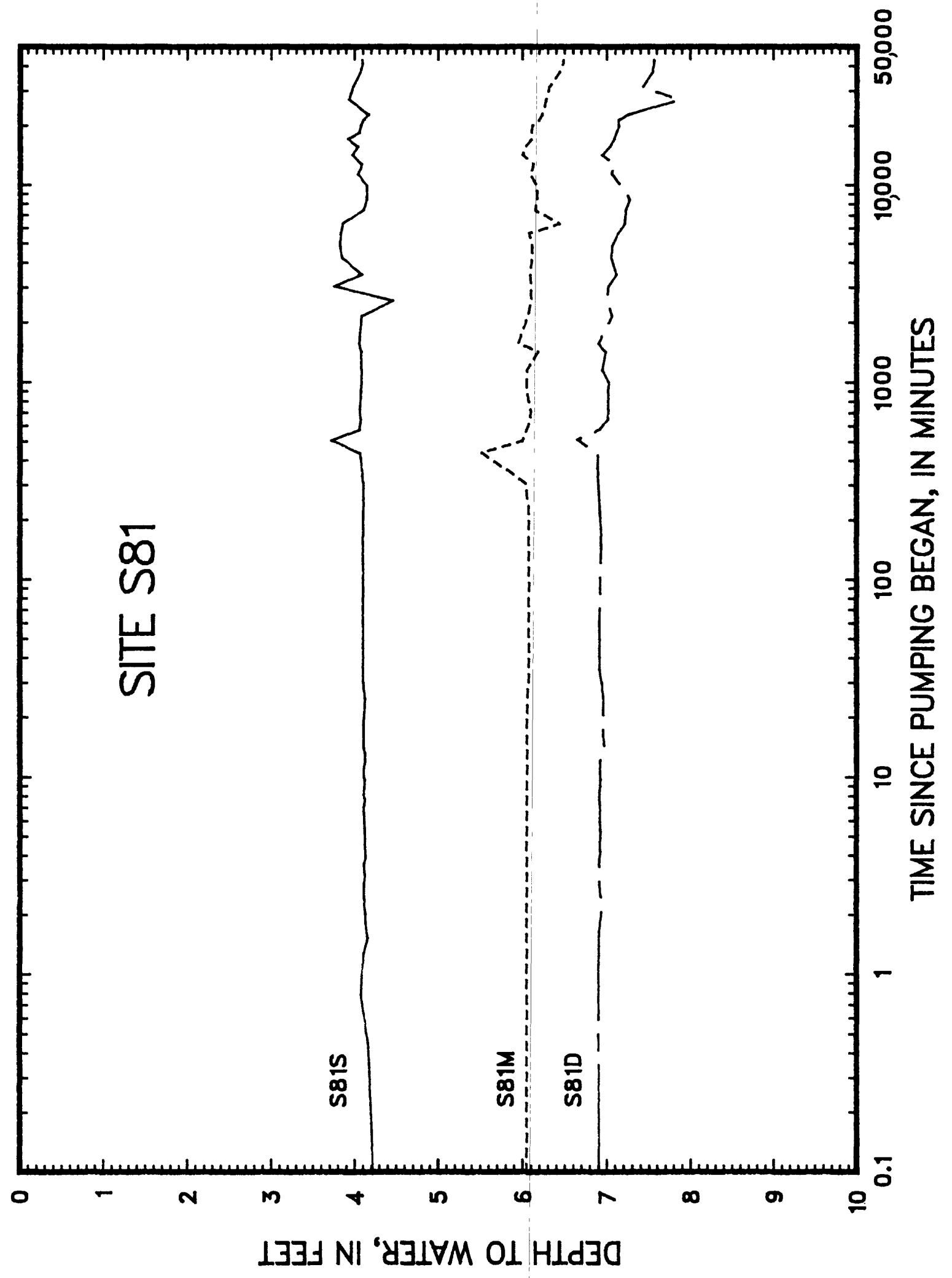

B- 18 


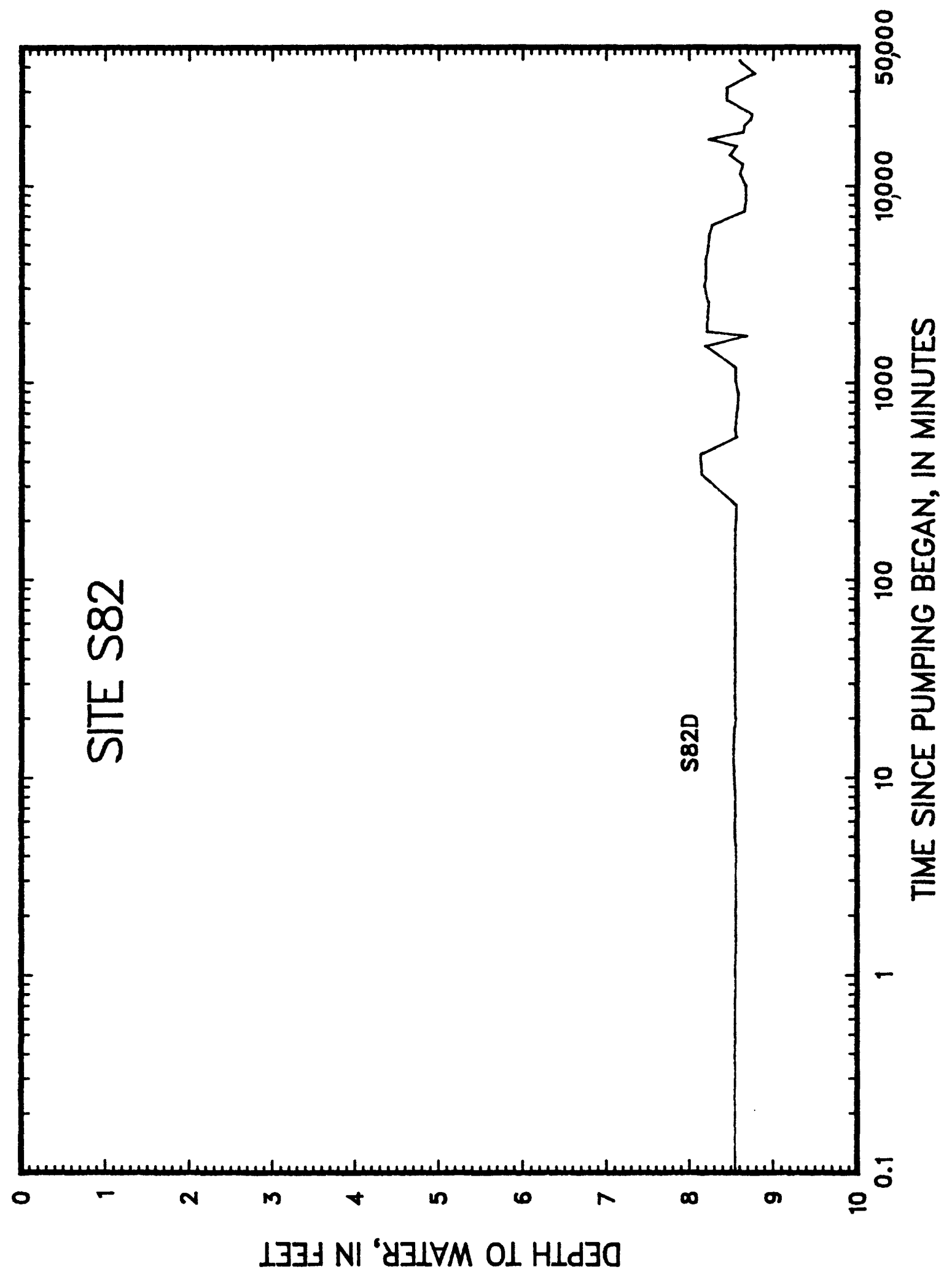

B-19 


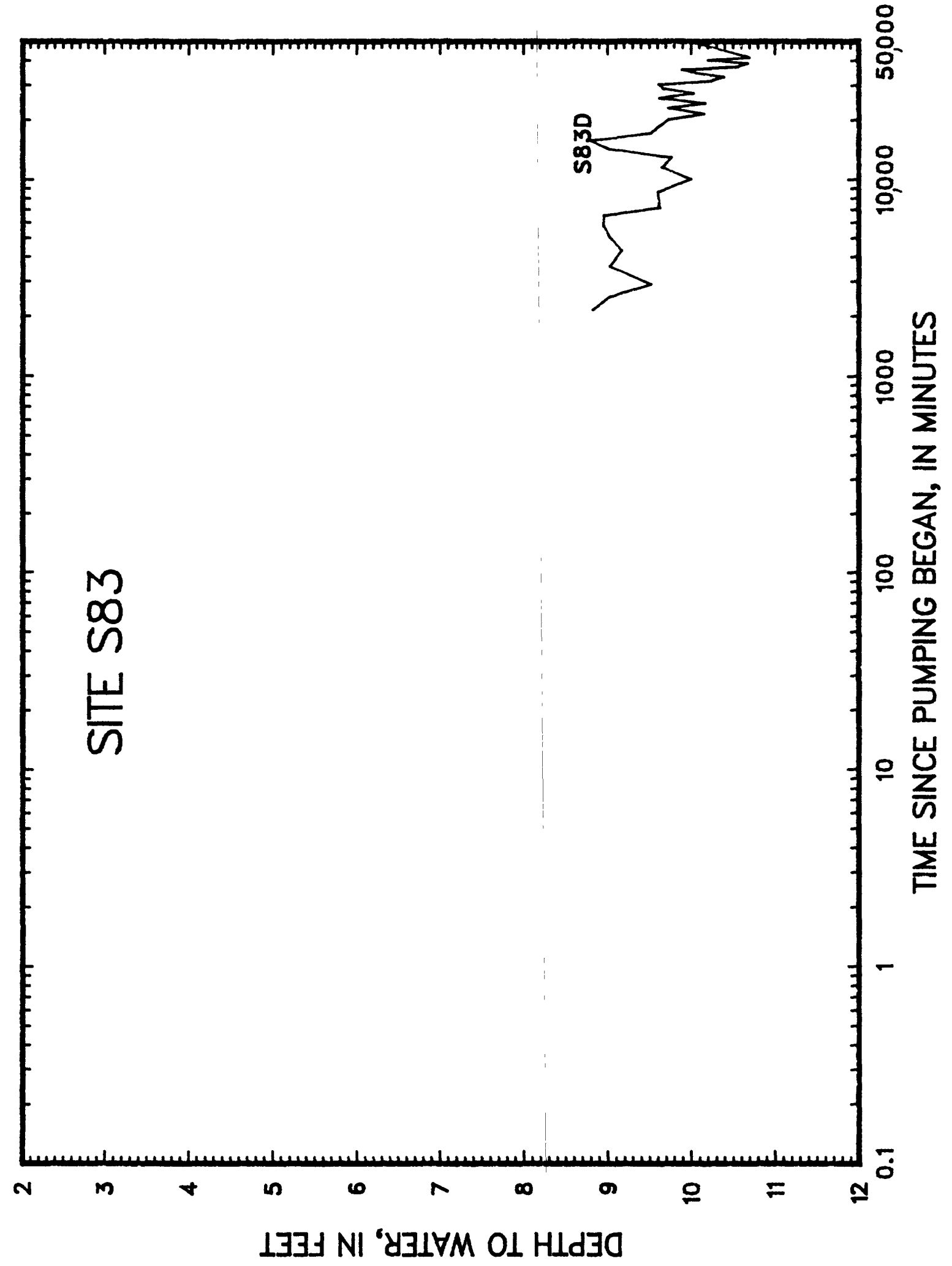

B-20 


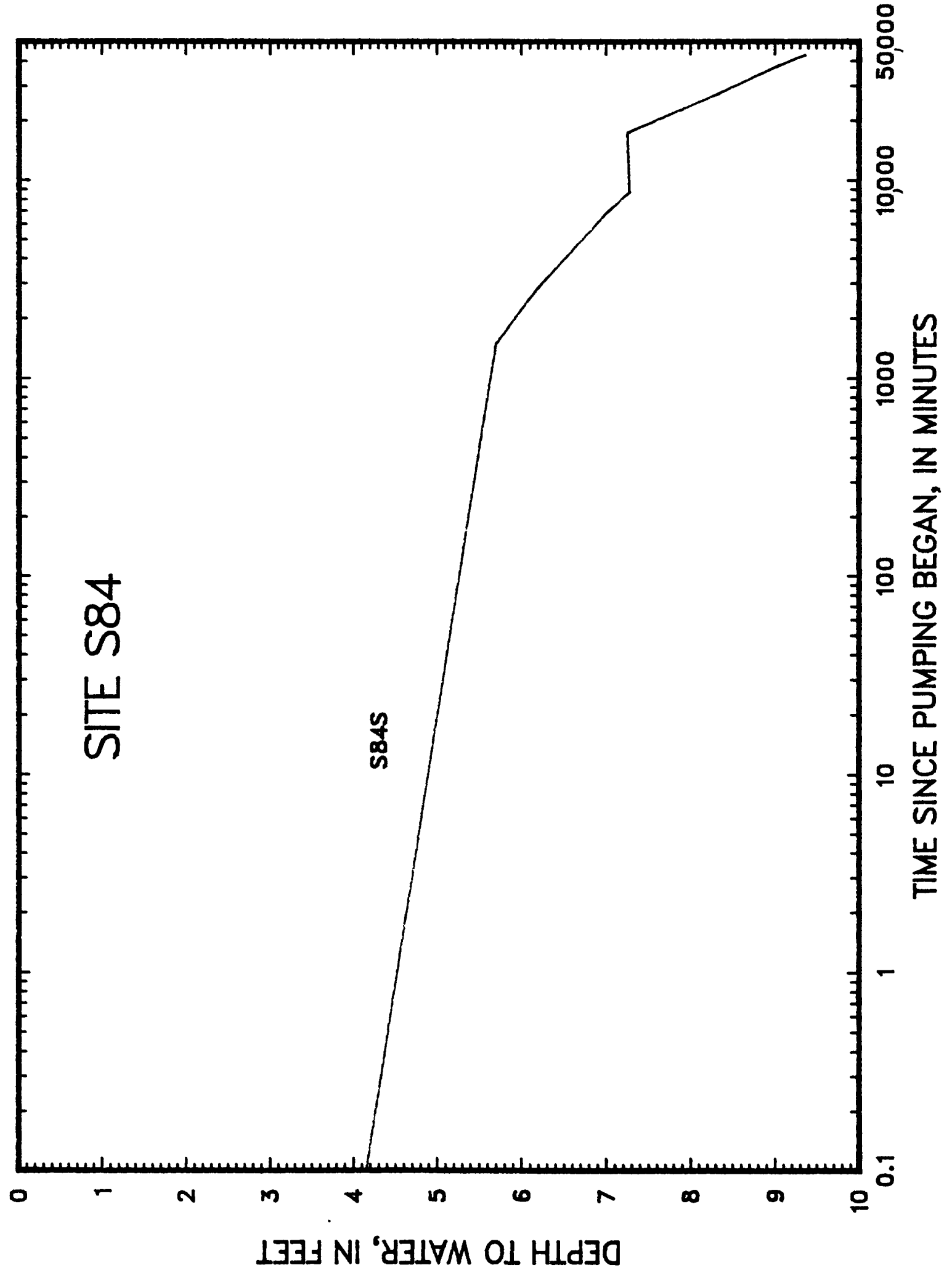

B-2 1 


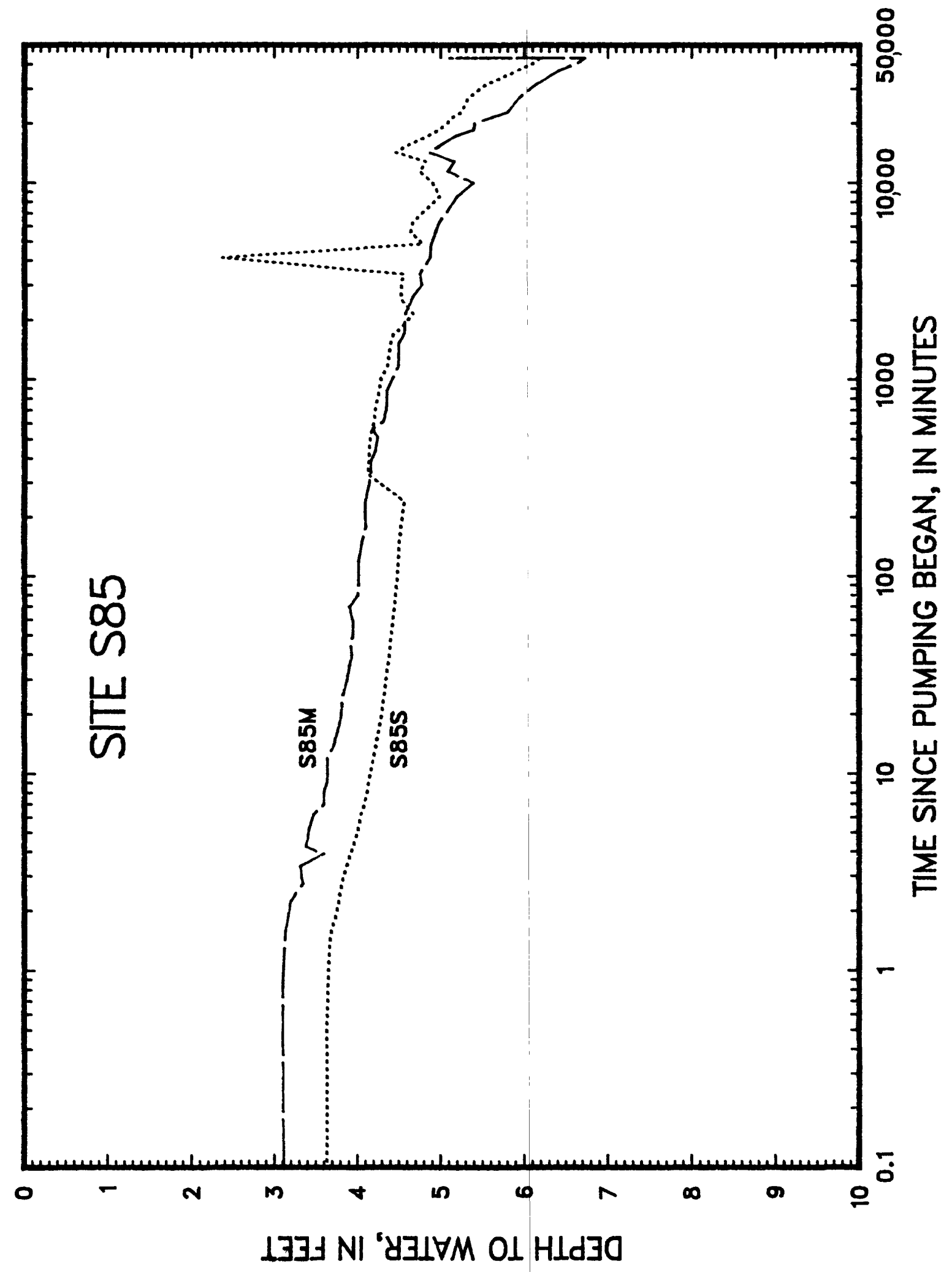

B-22 


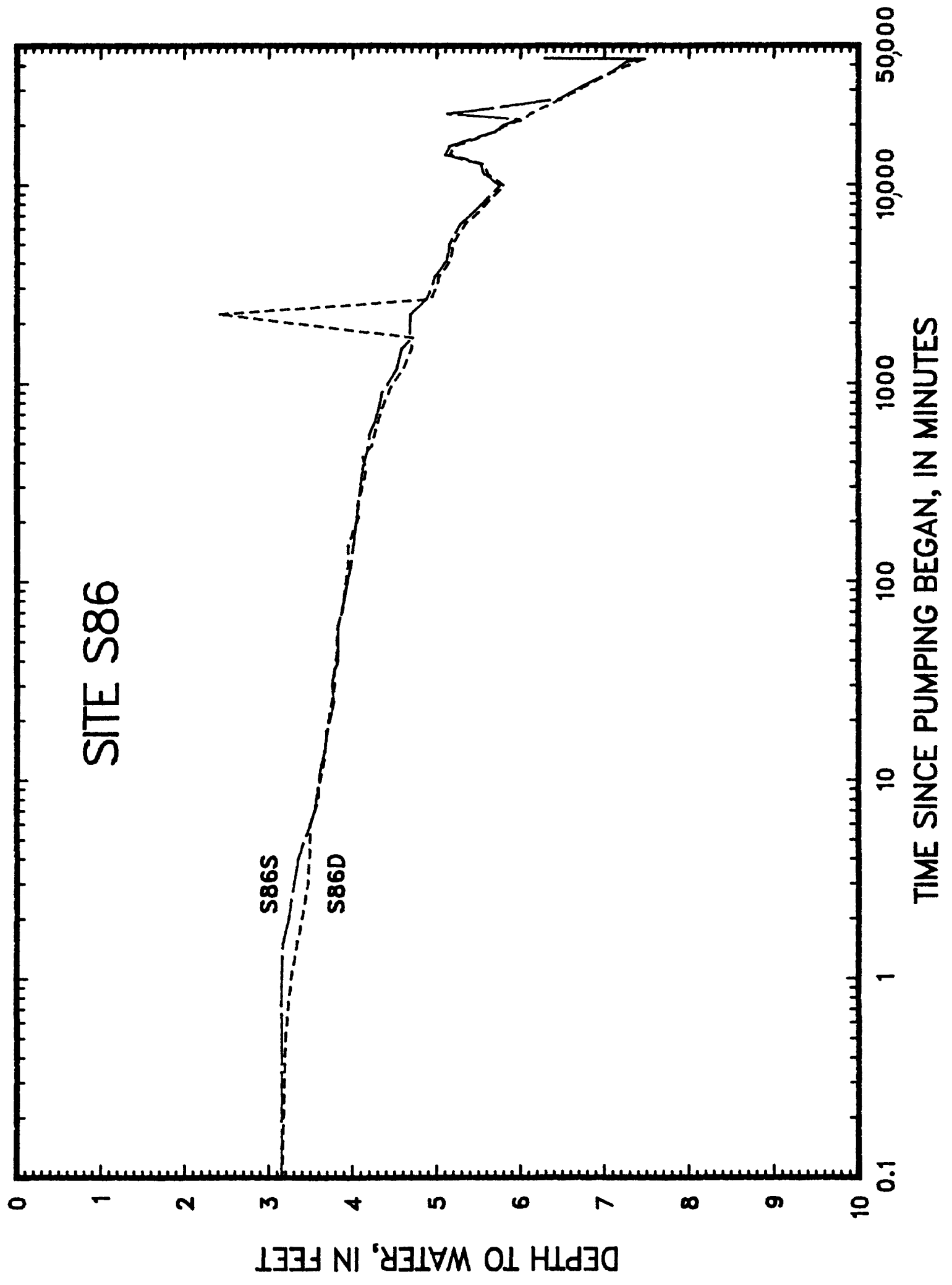




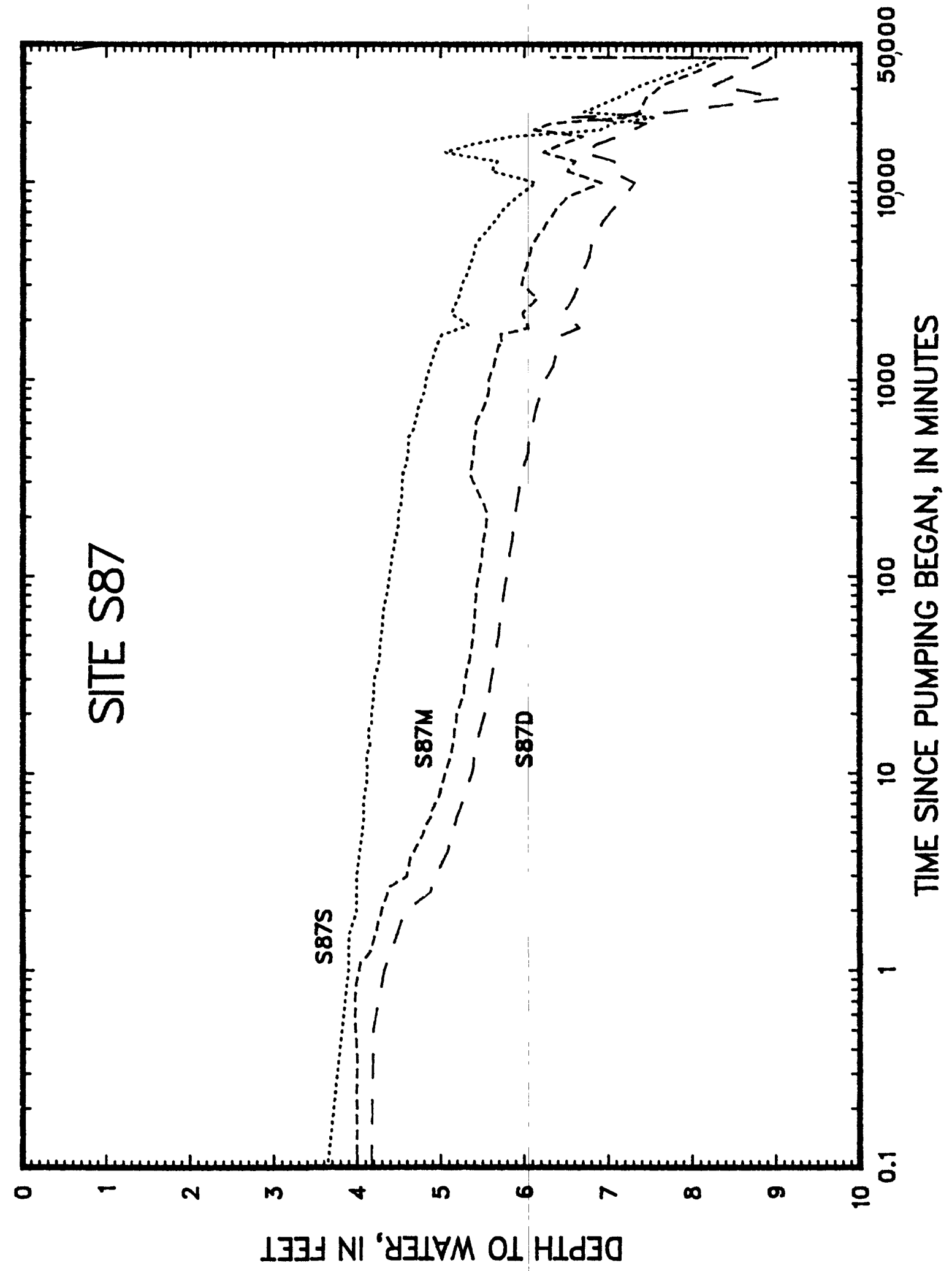




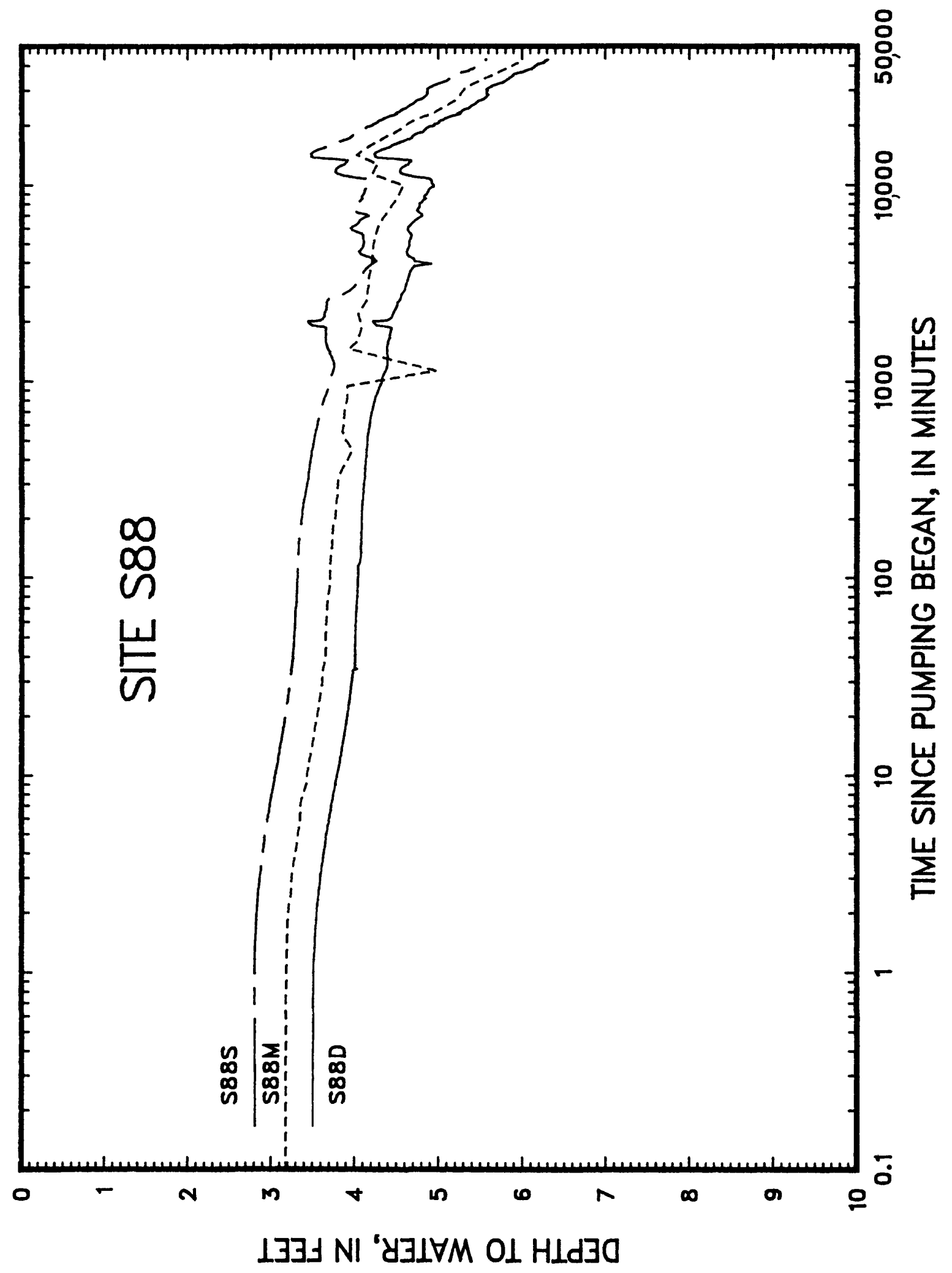




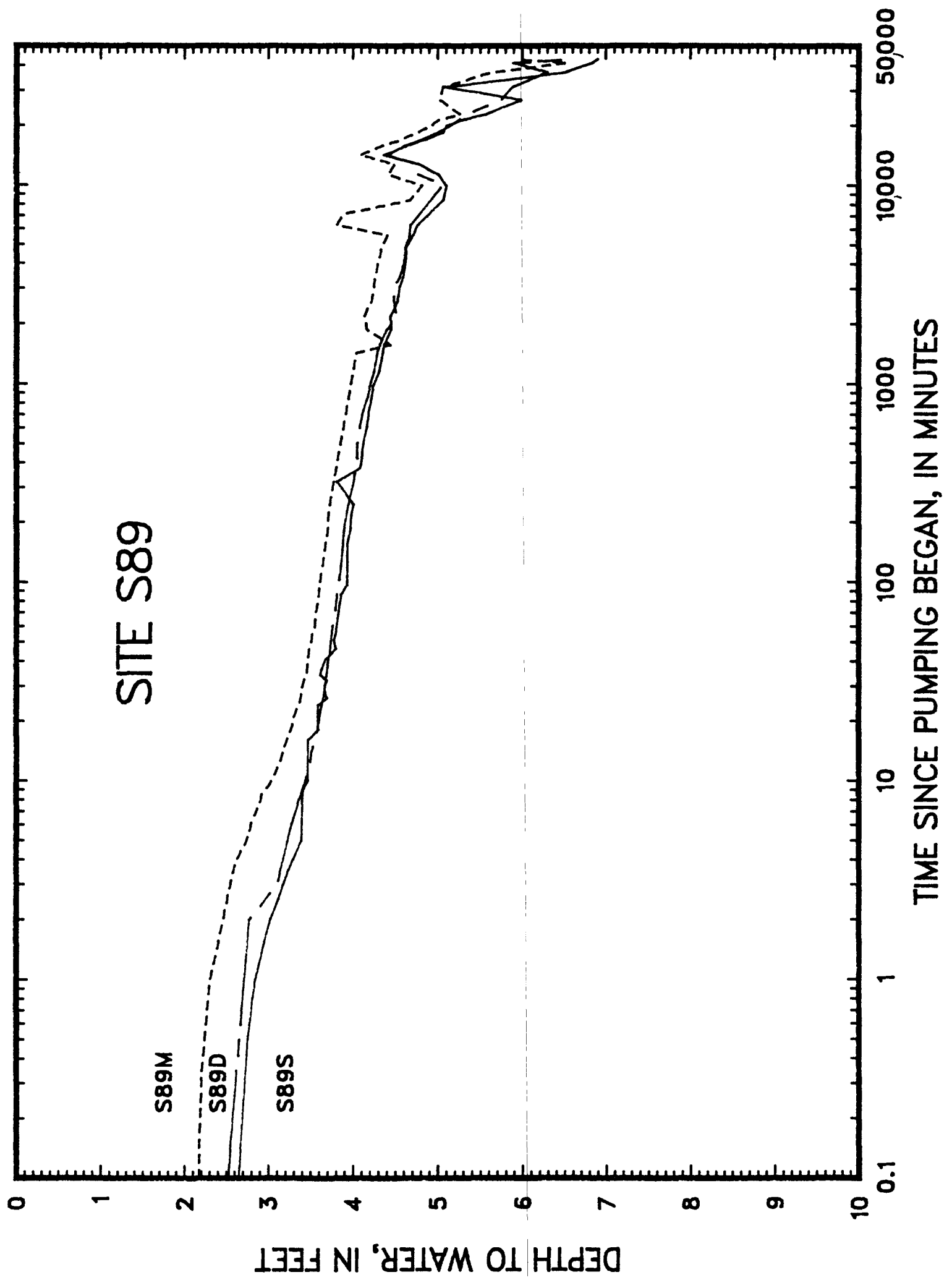

B-26 


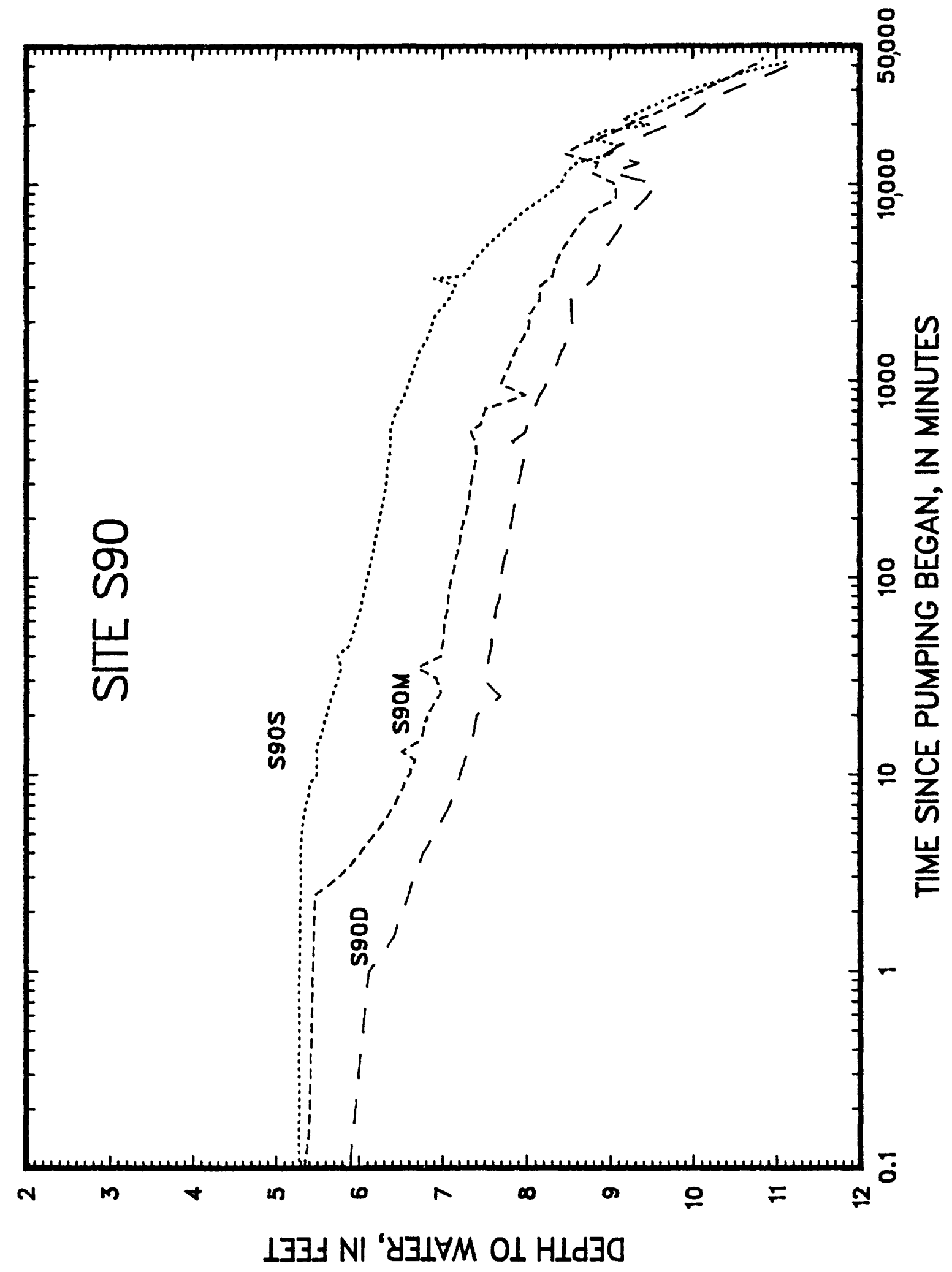

B-27 


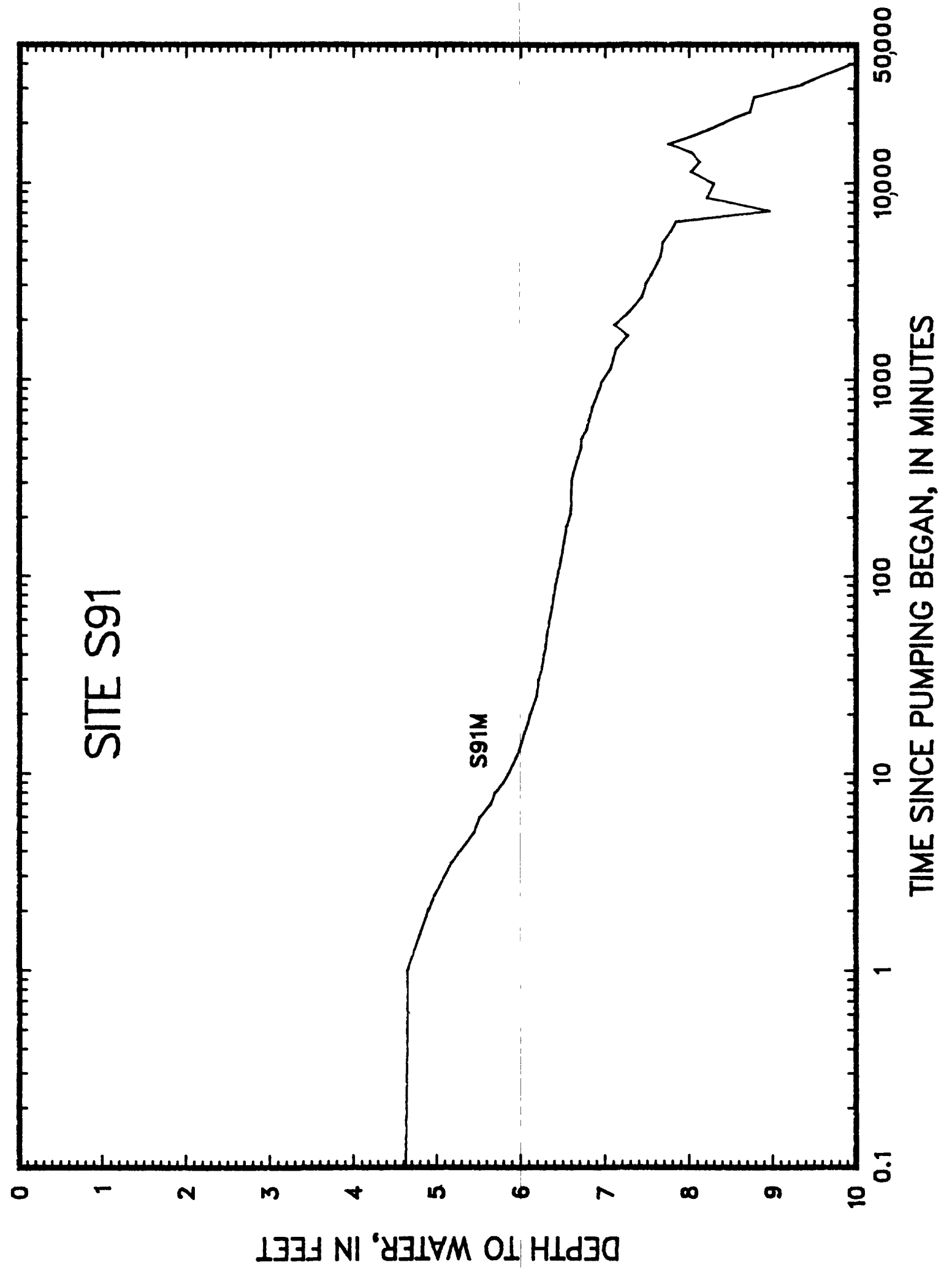

B-28 


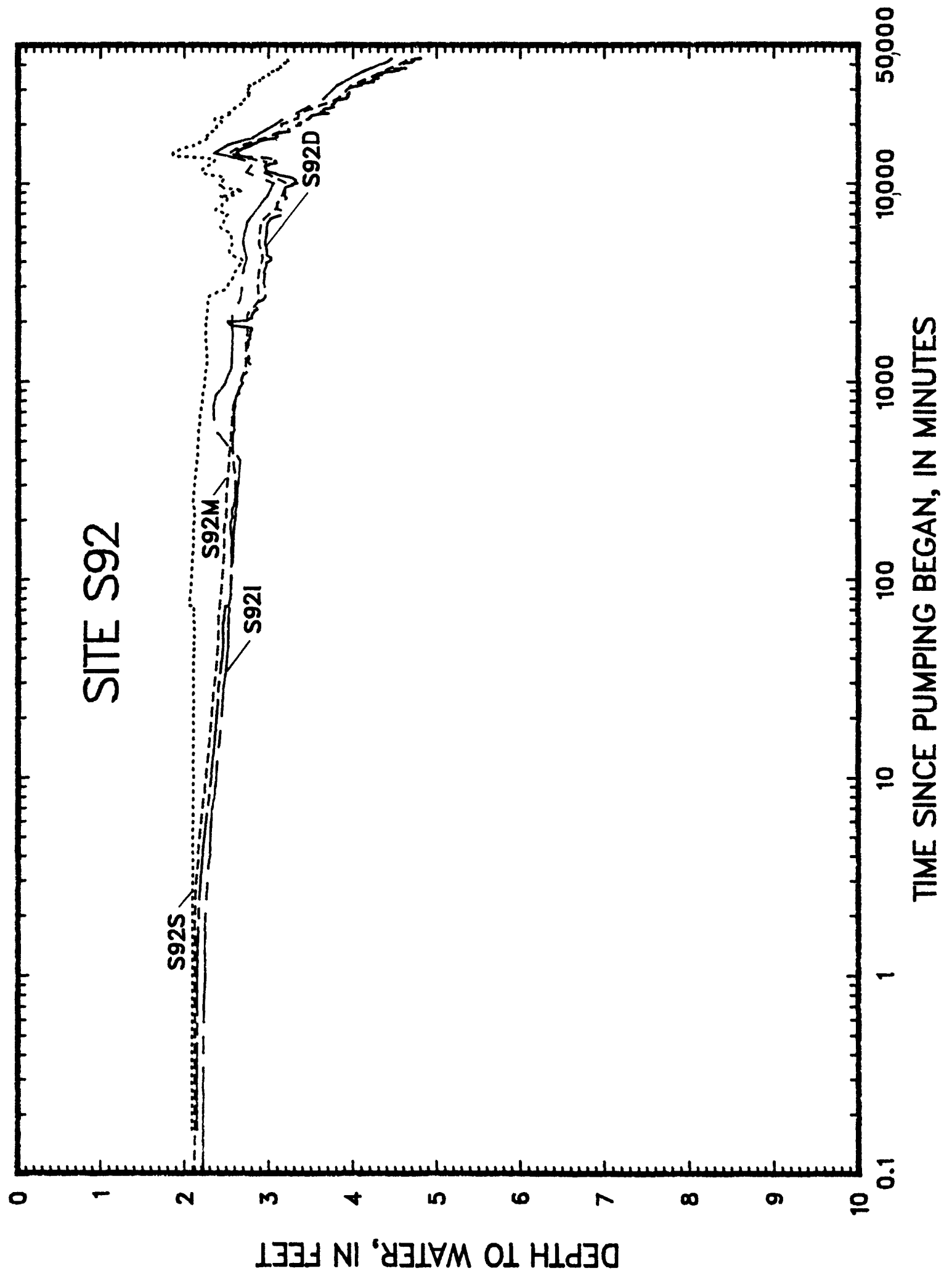

B-29 


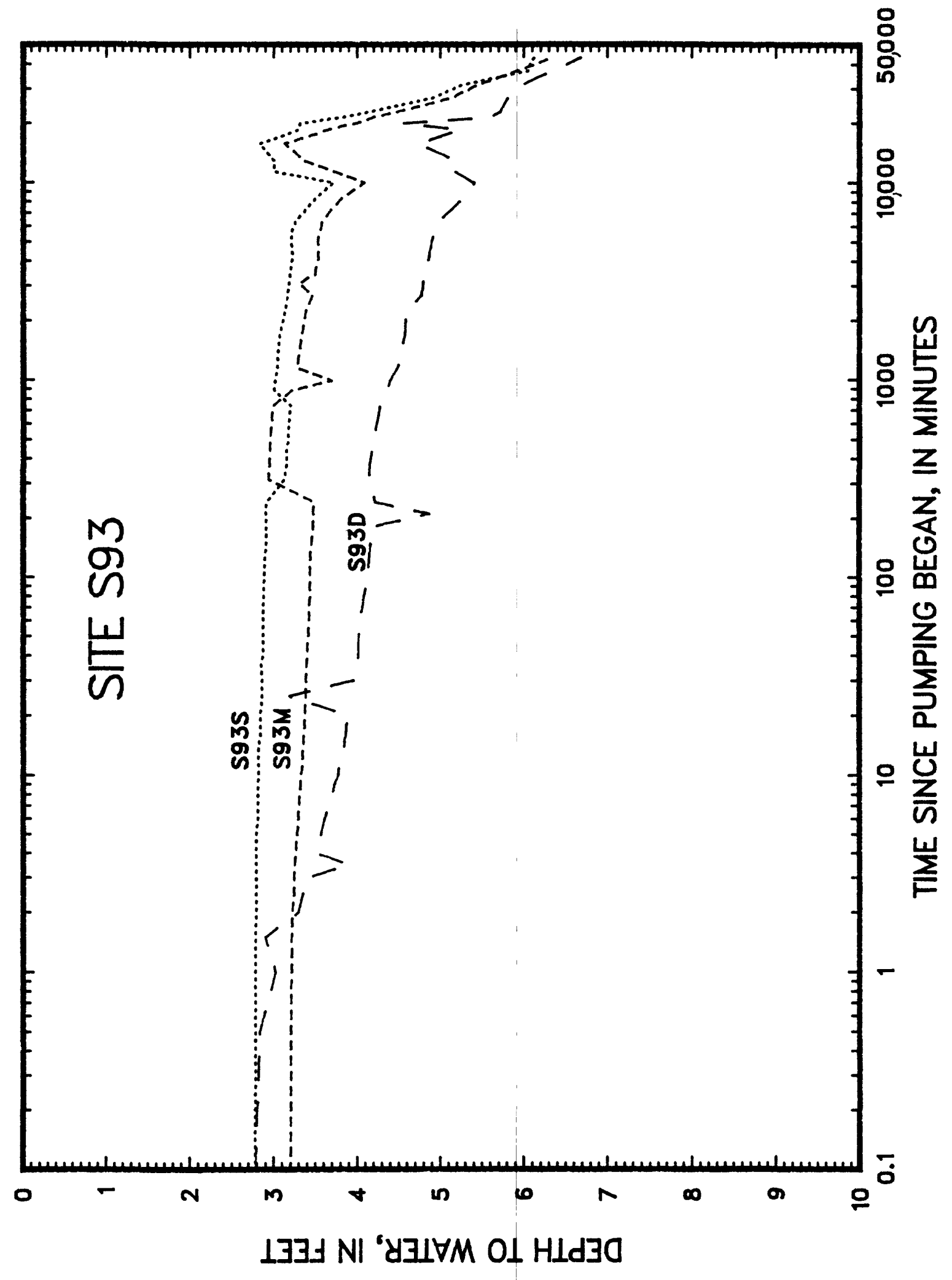

B-30 


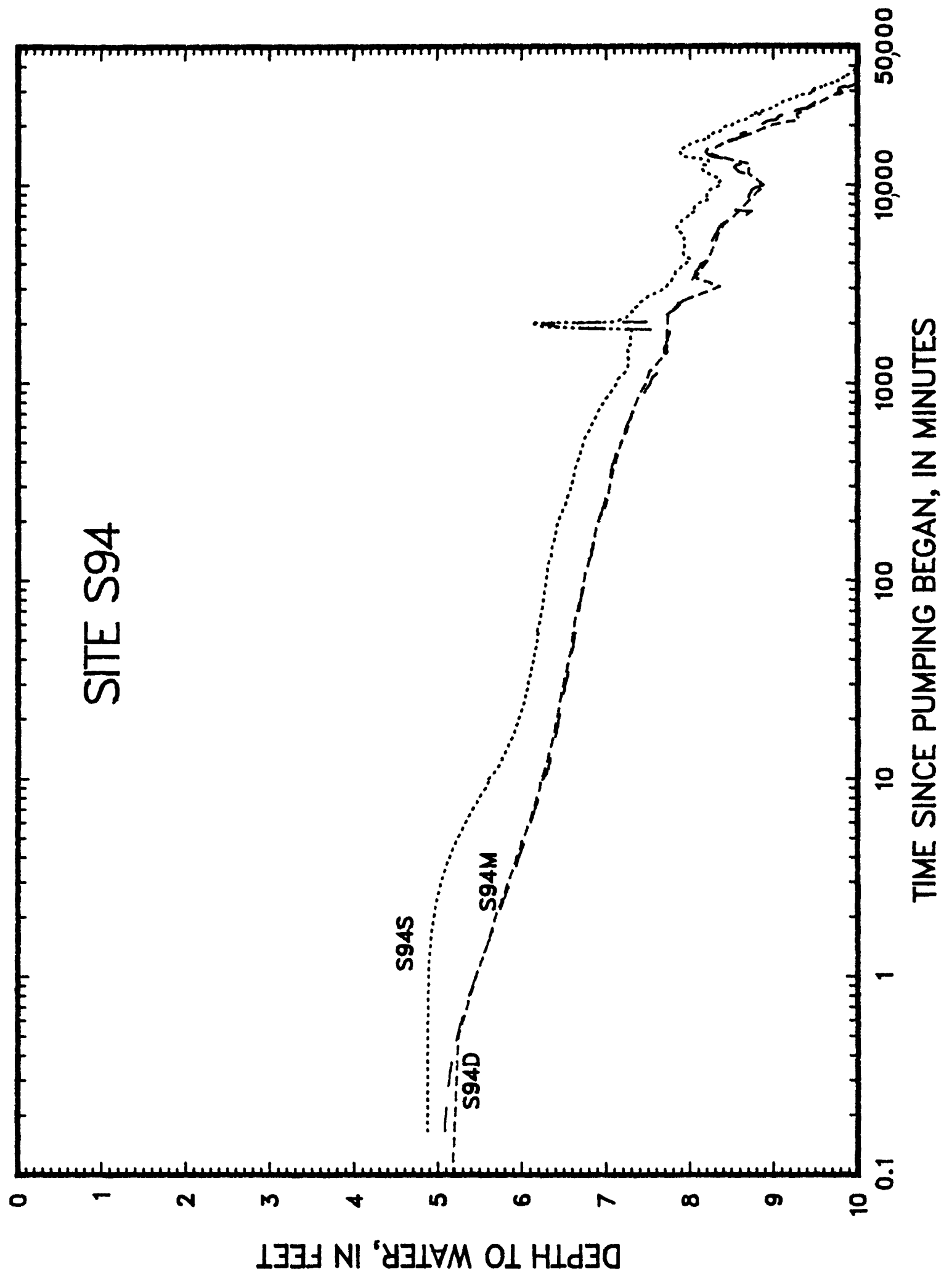




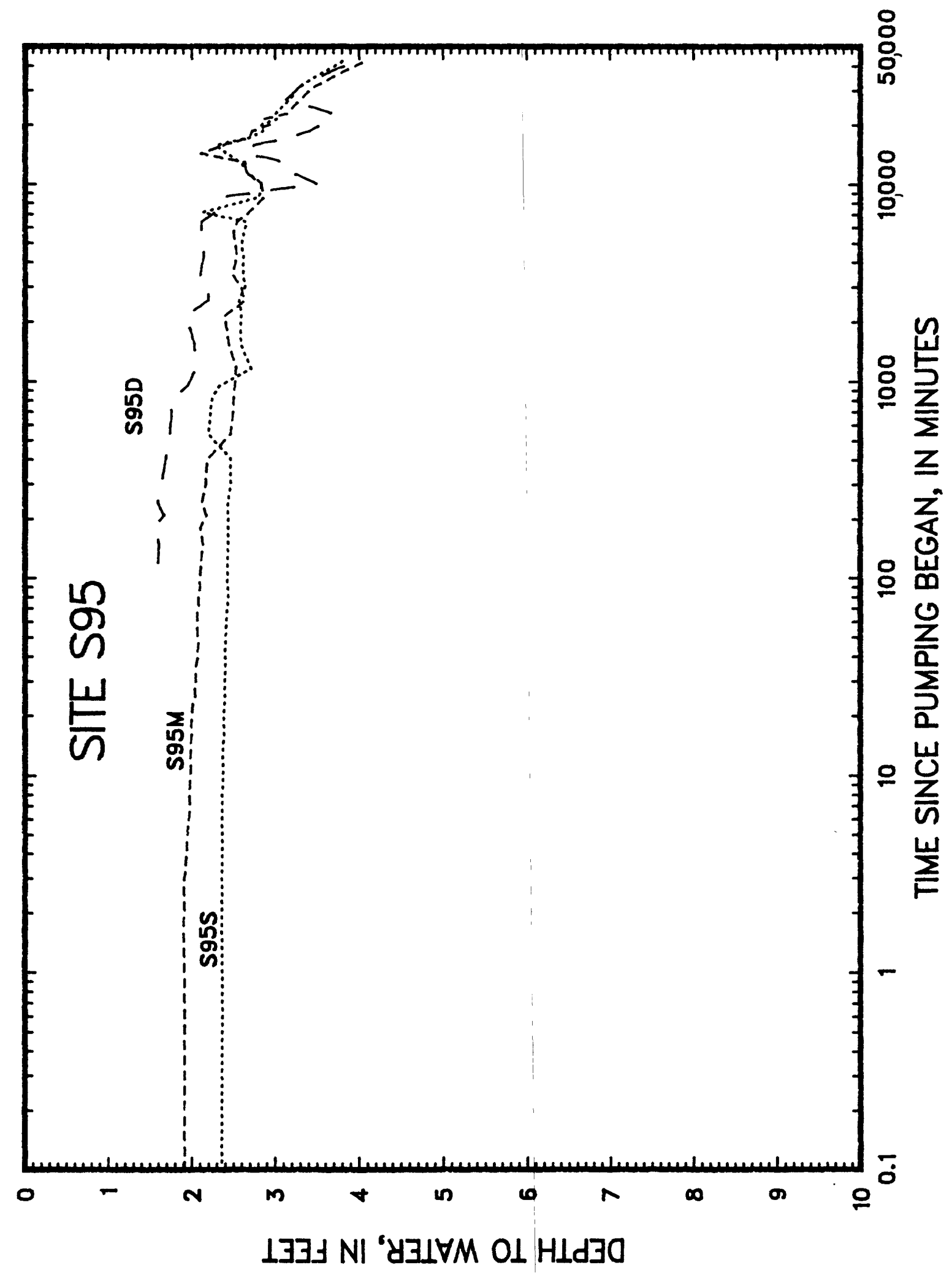

B-32 


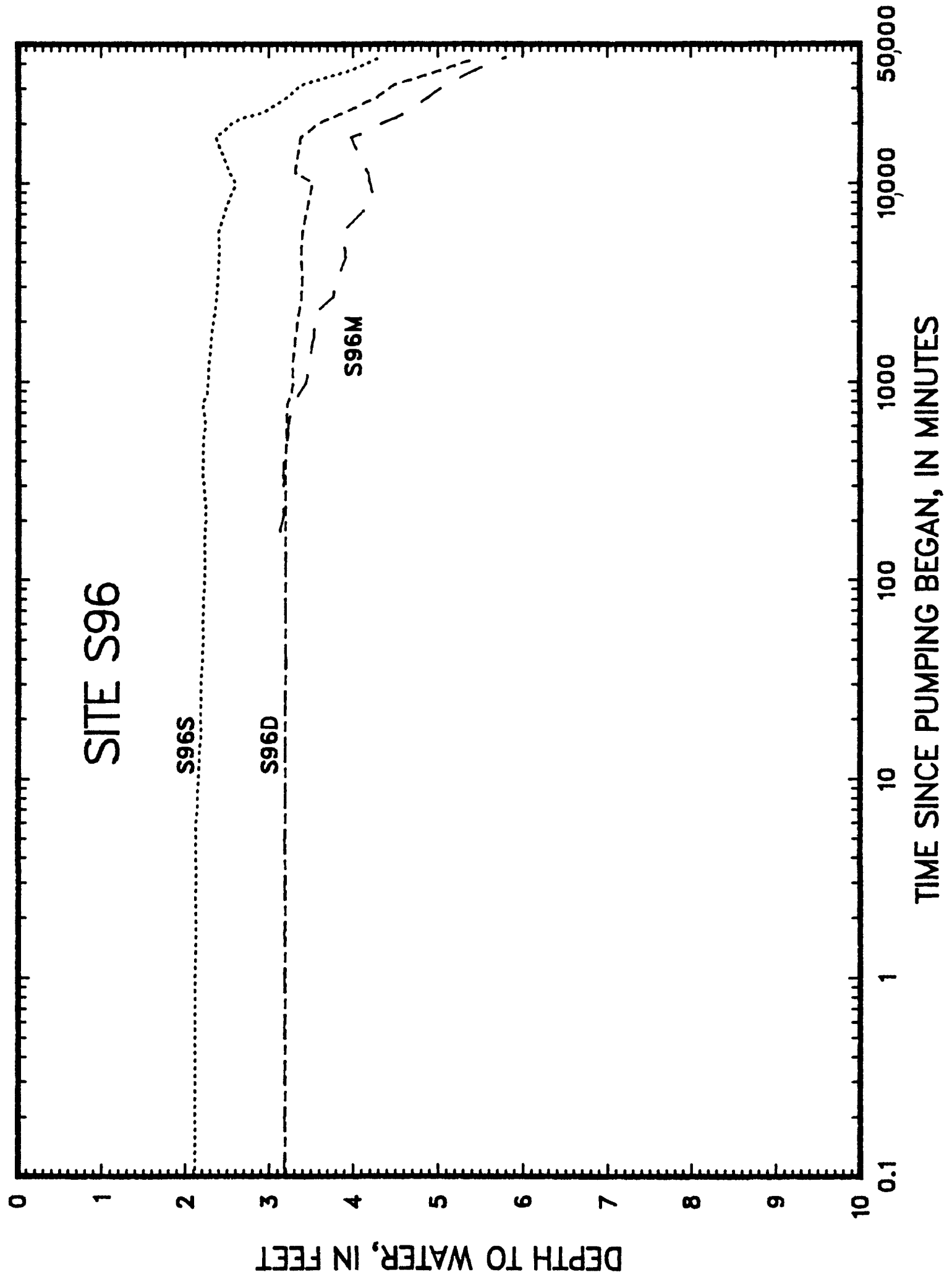




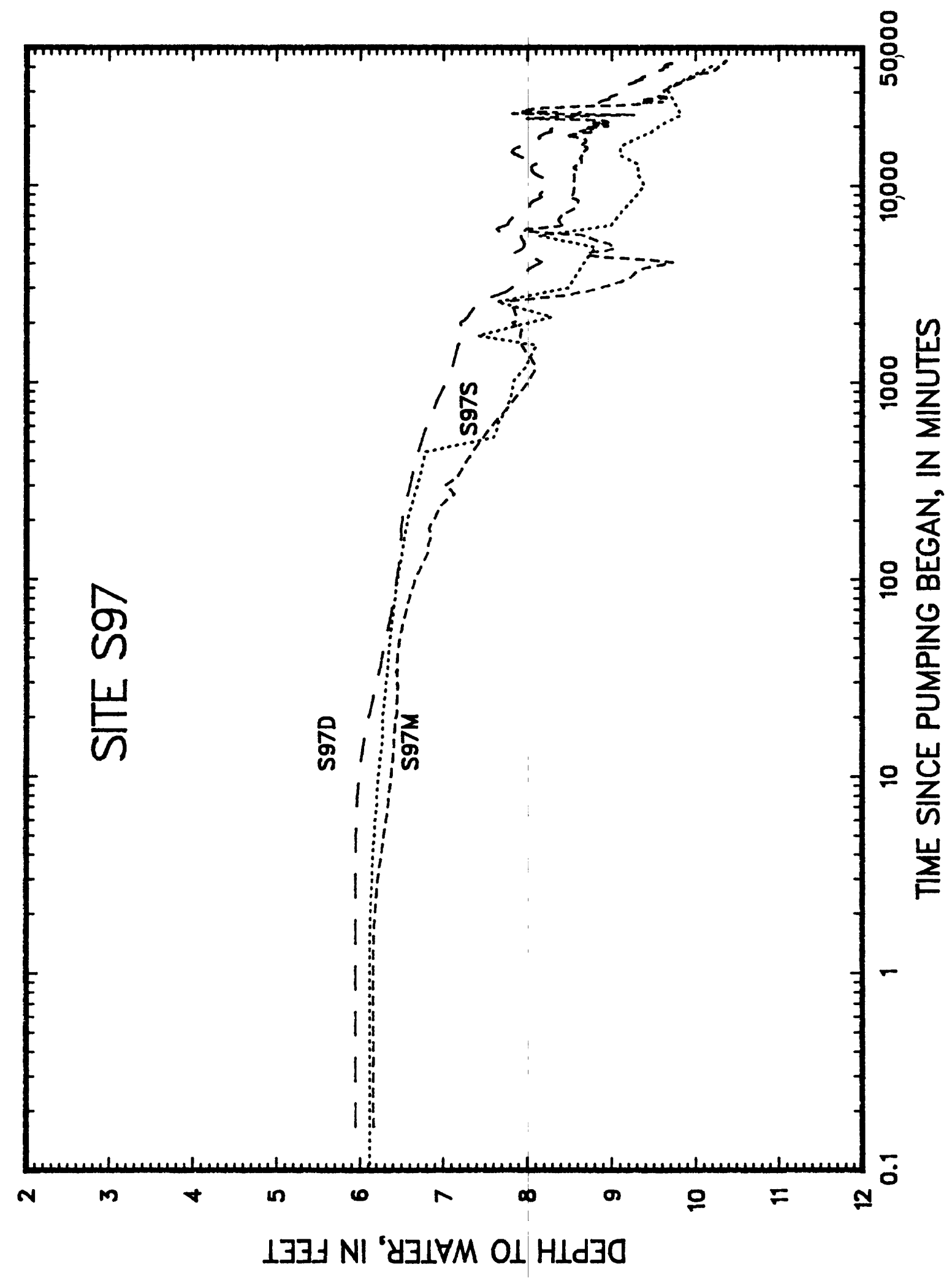

B-34 


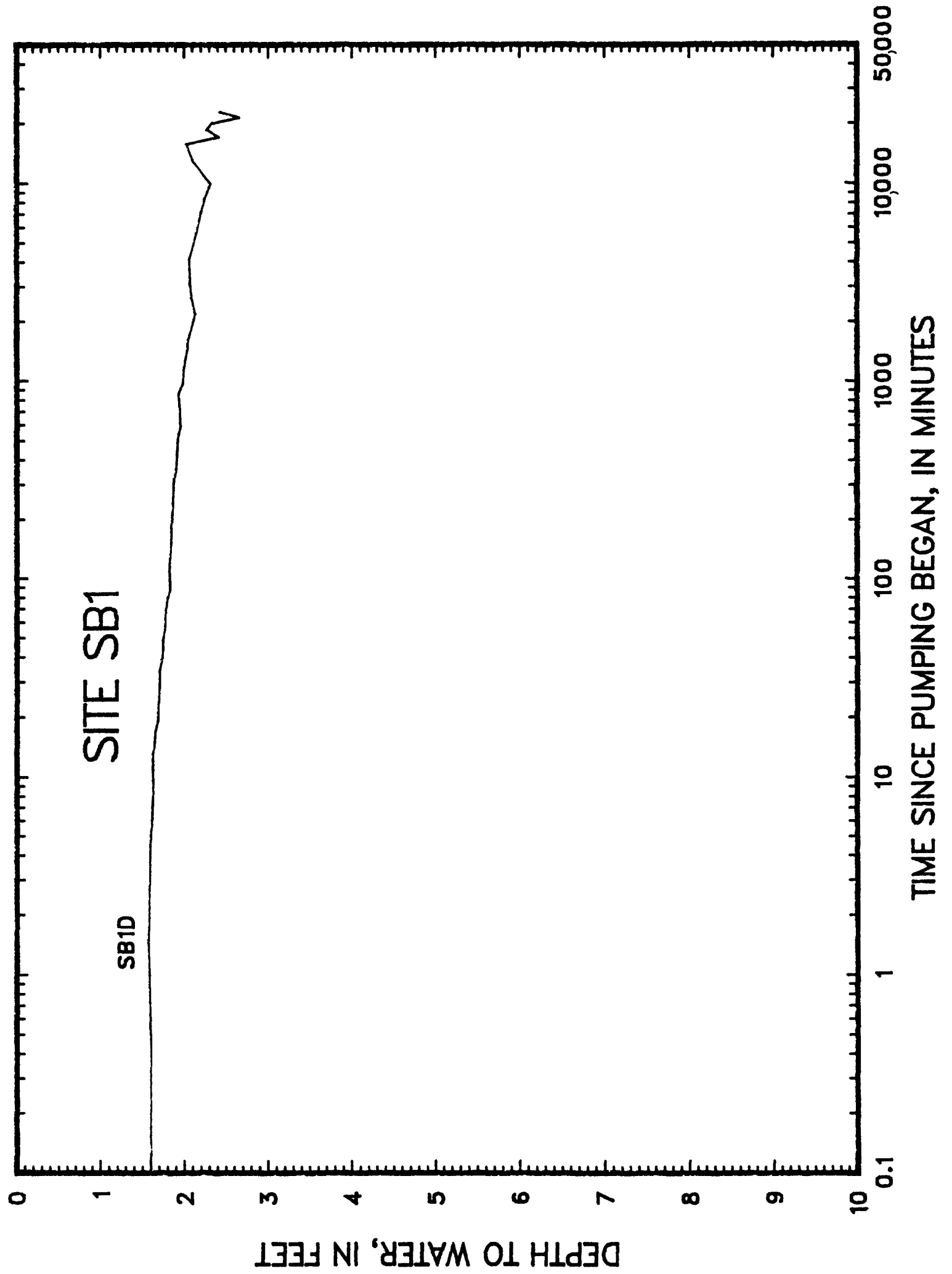

B-35 


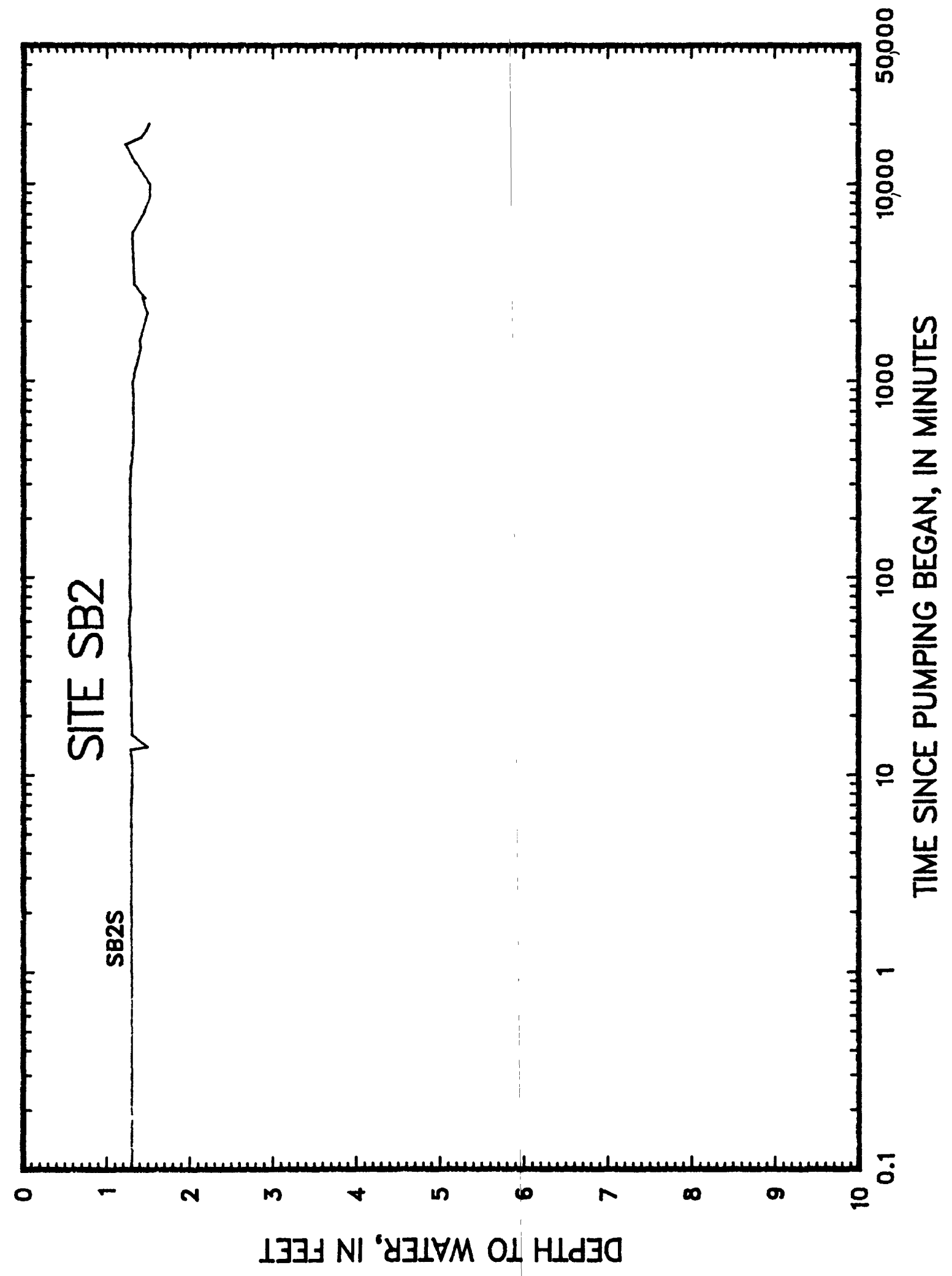

B-36 


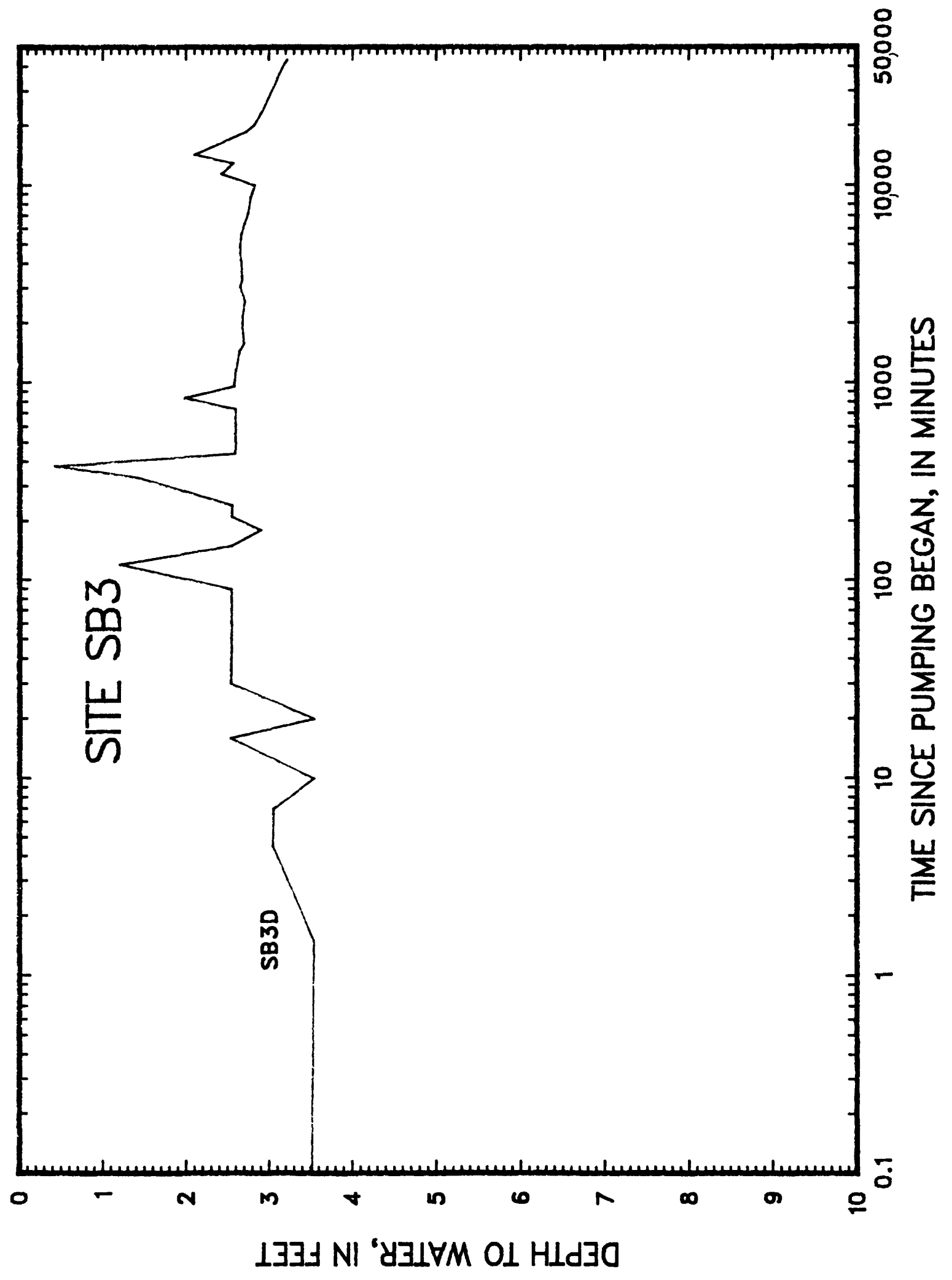

B-37 


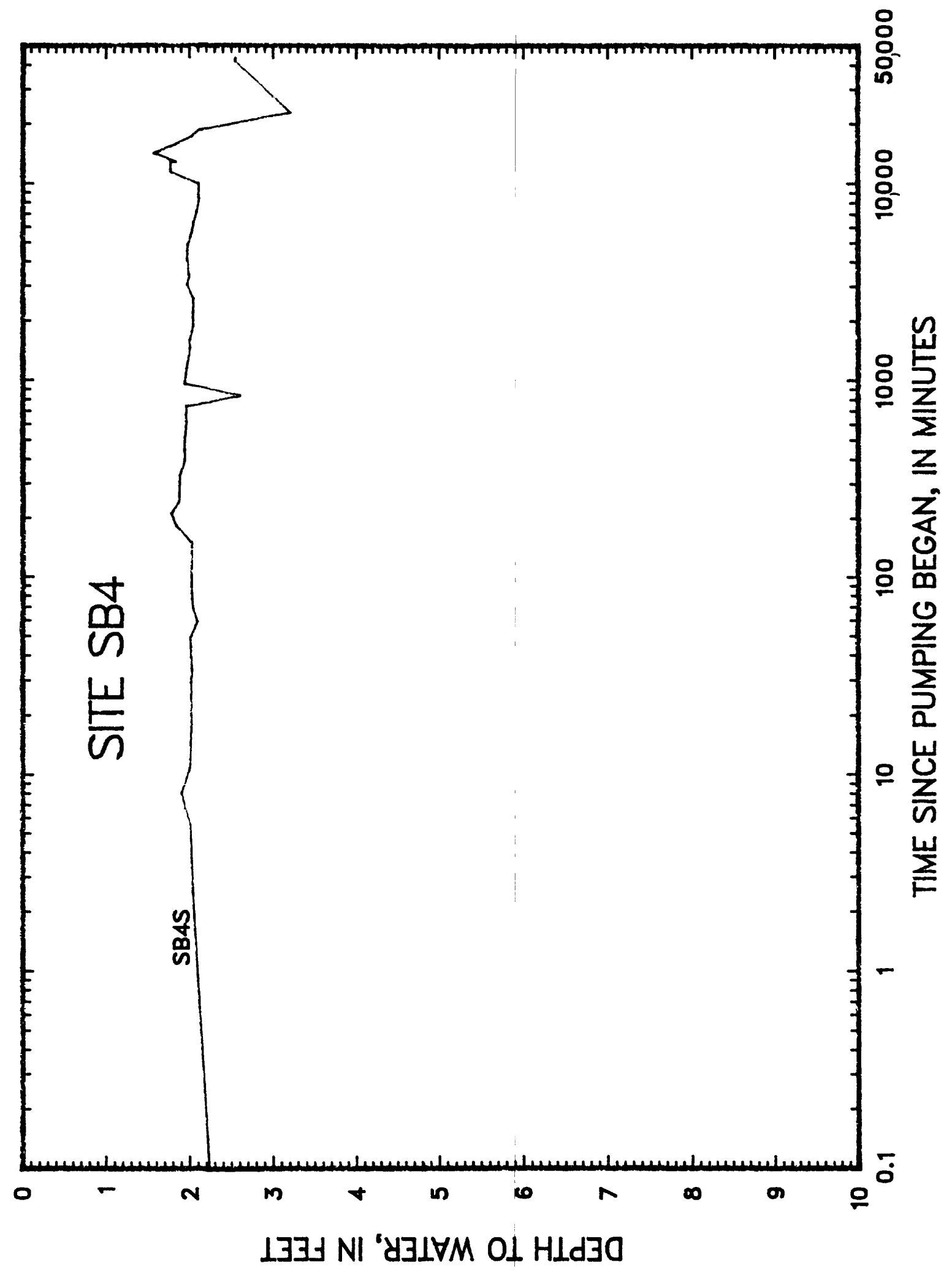




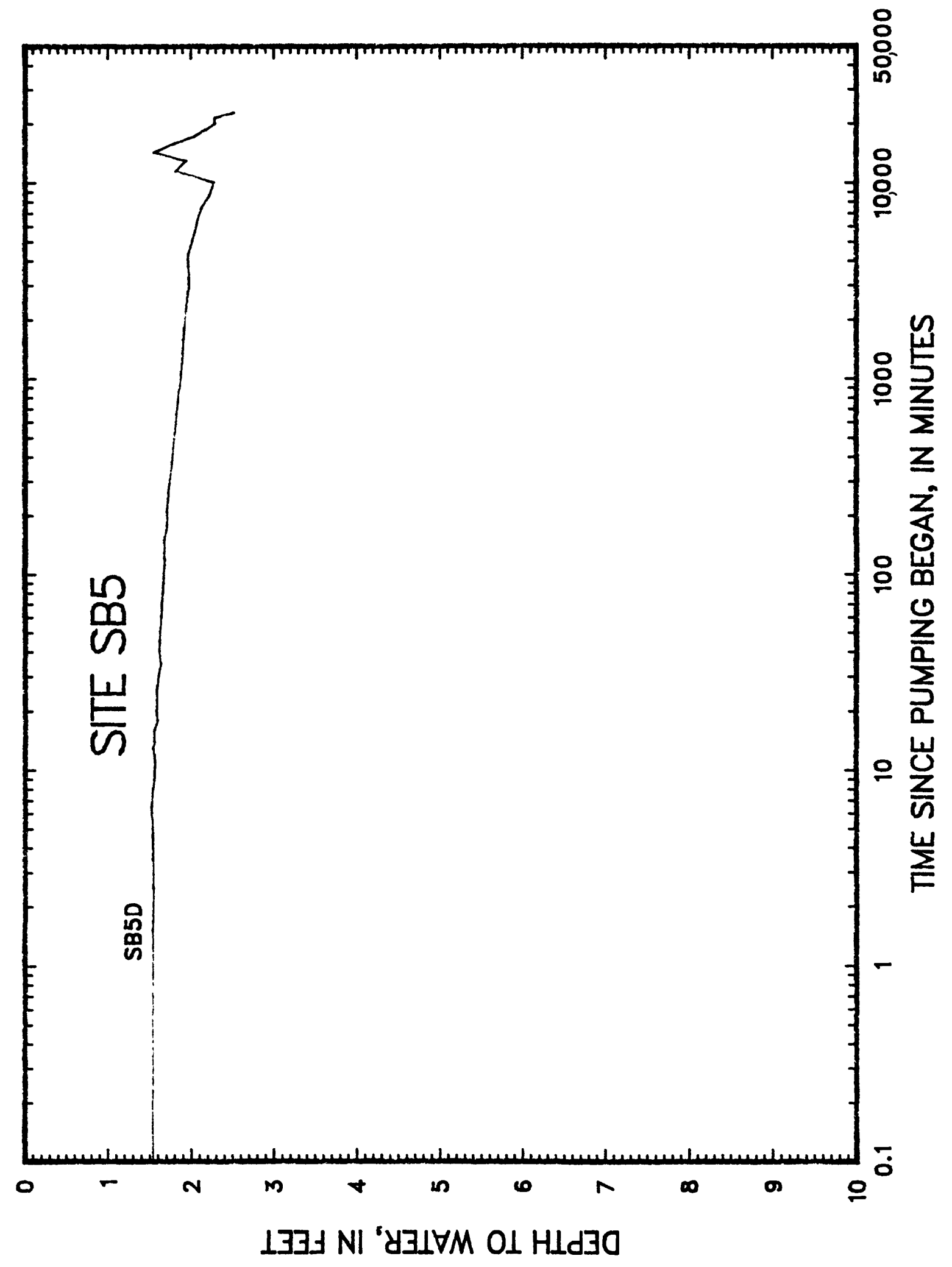




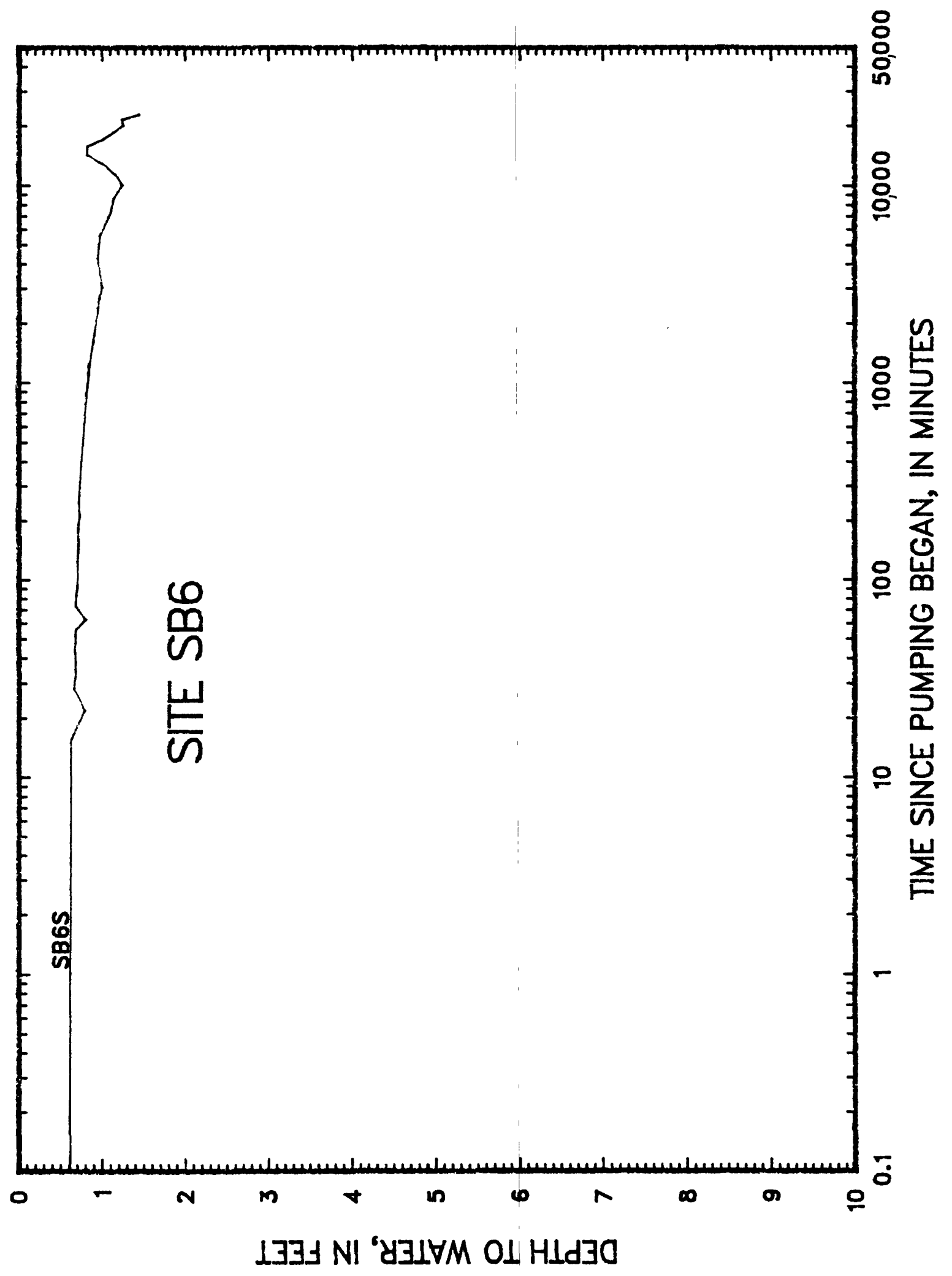




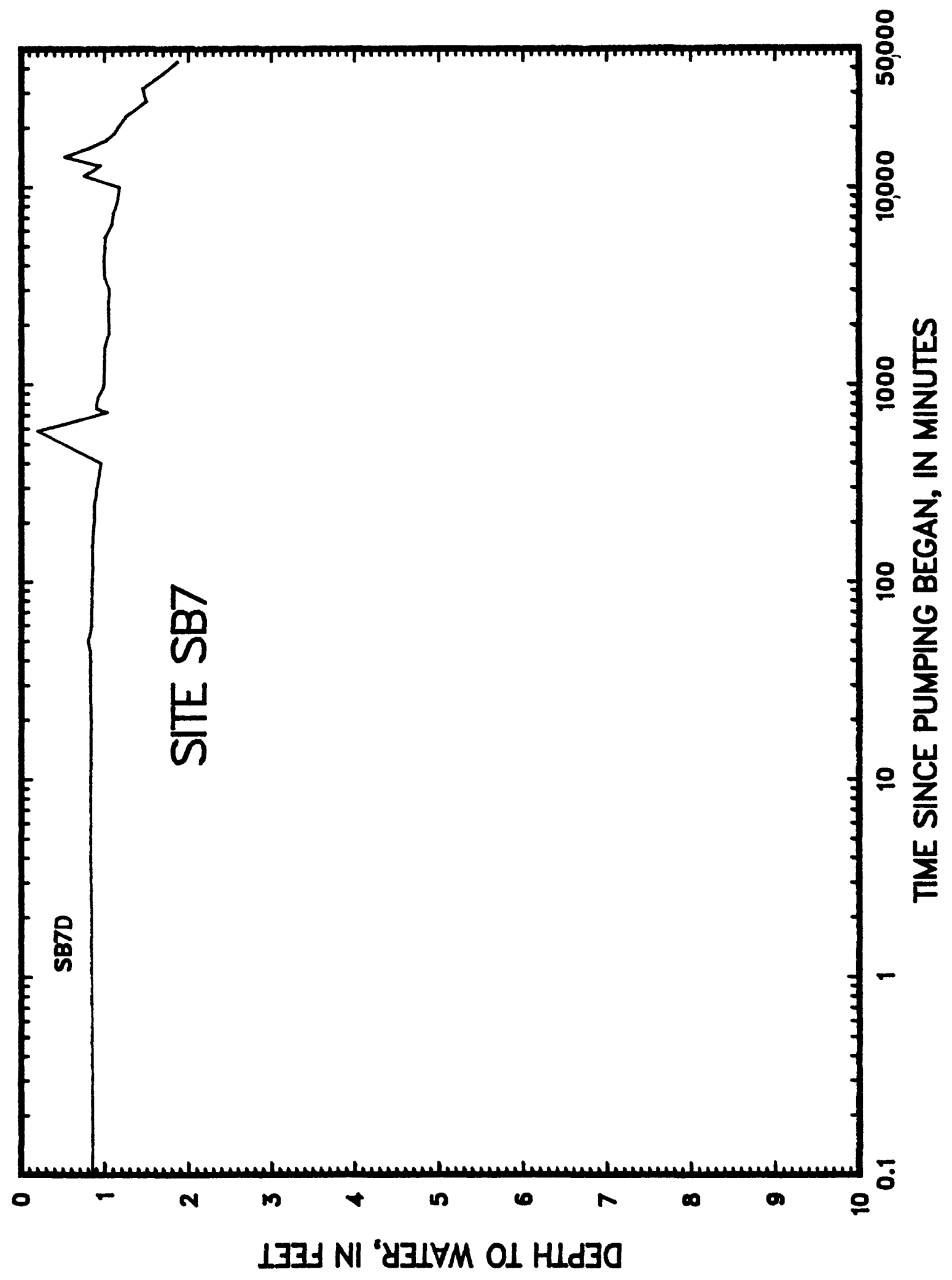

B-41 


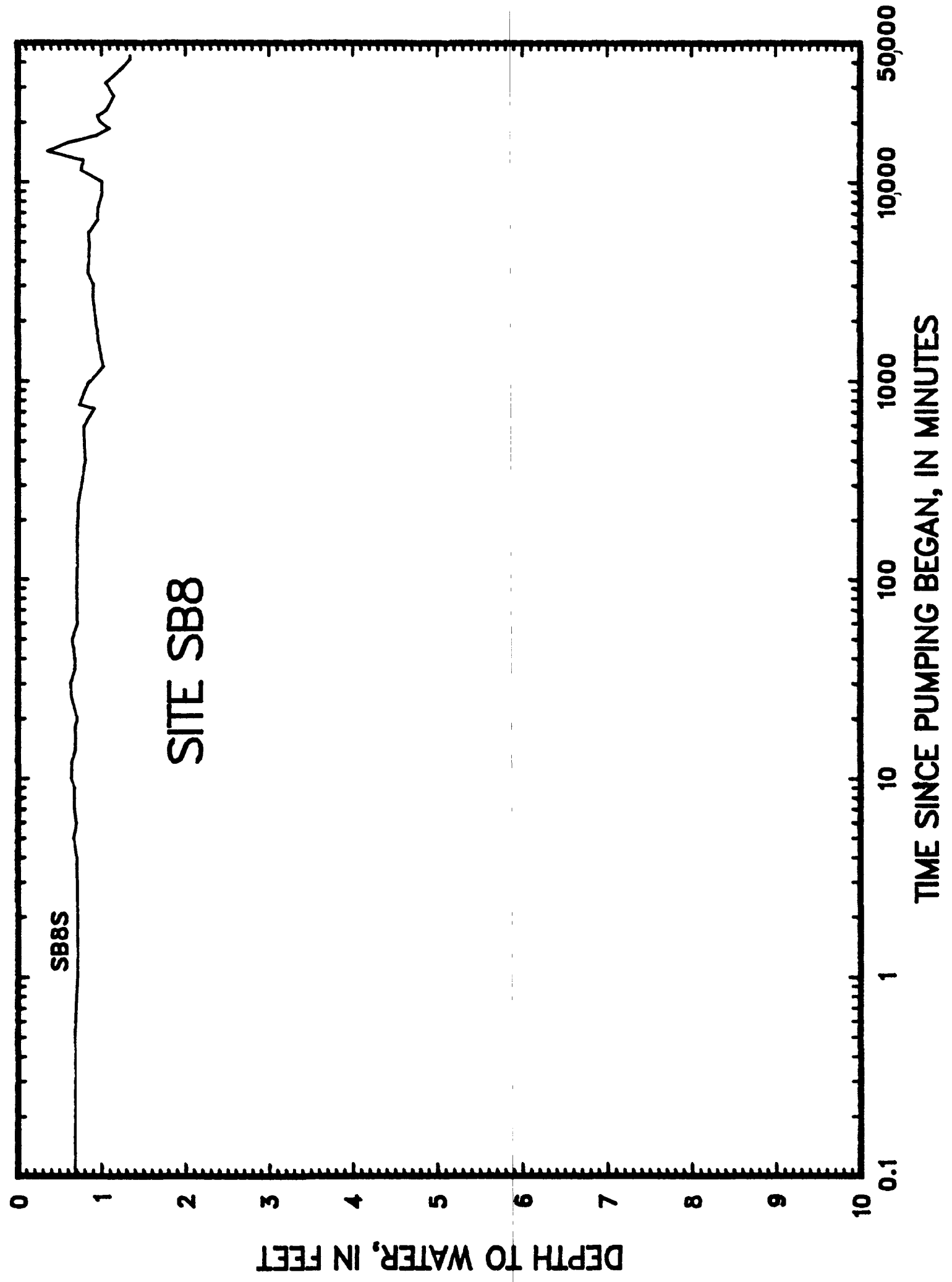

B-4 2 


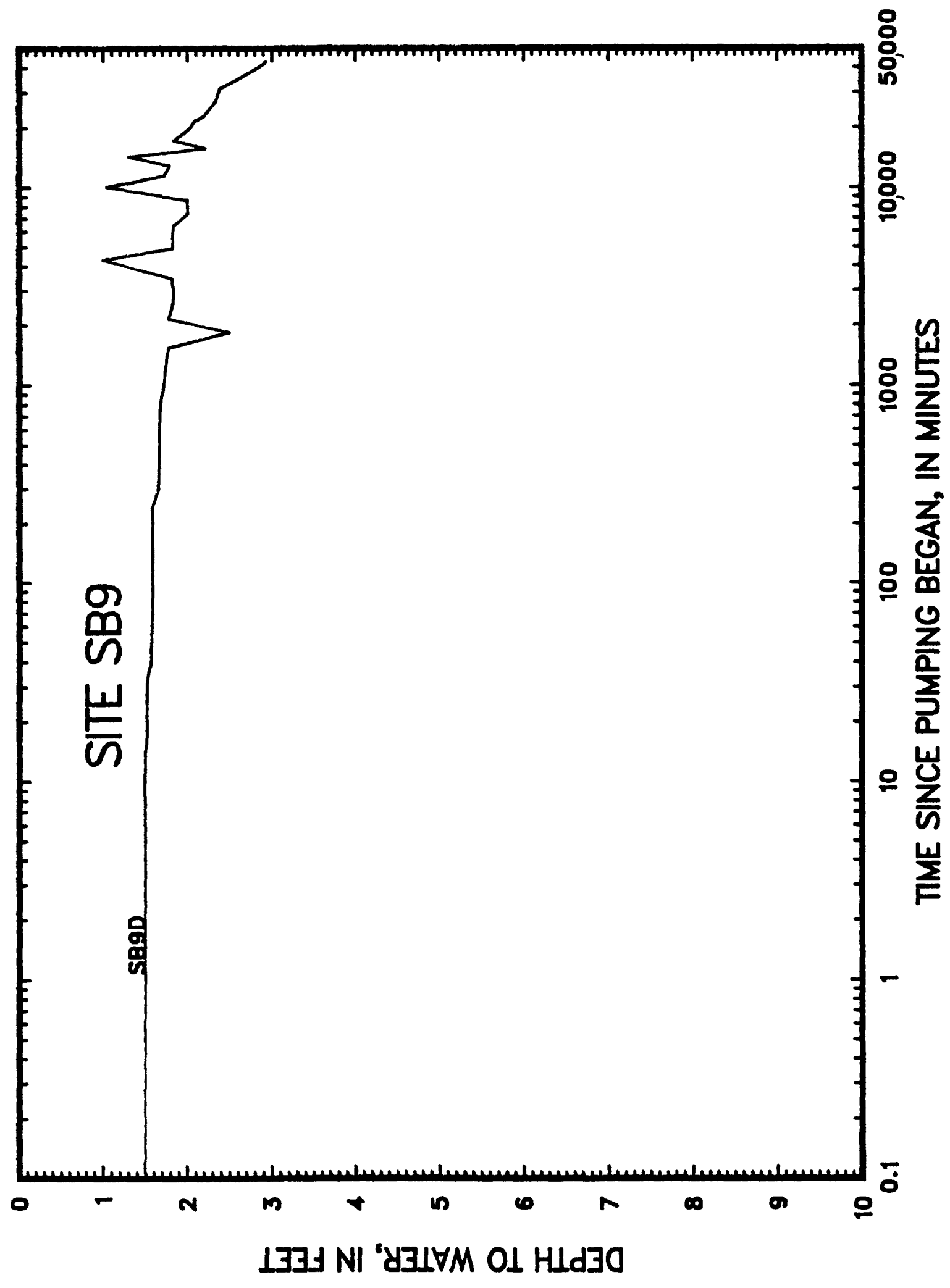




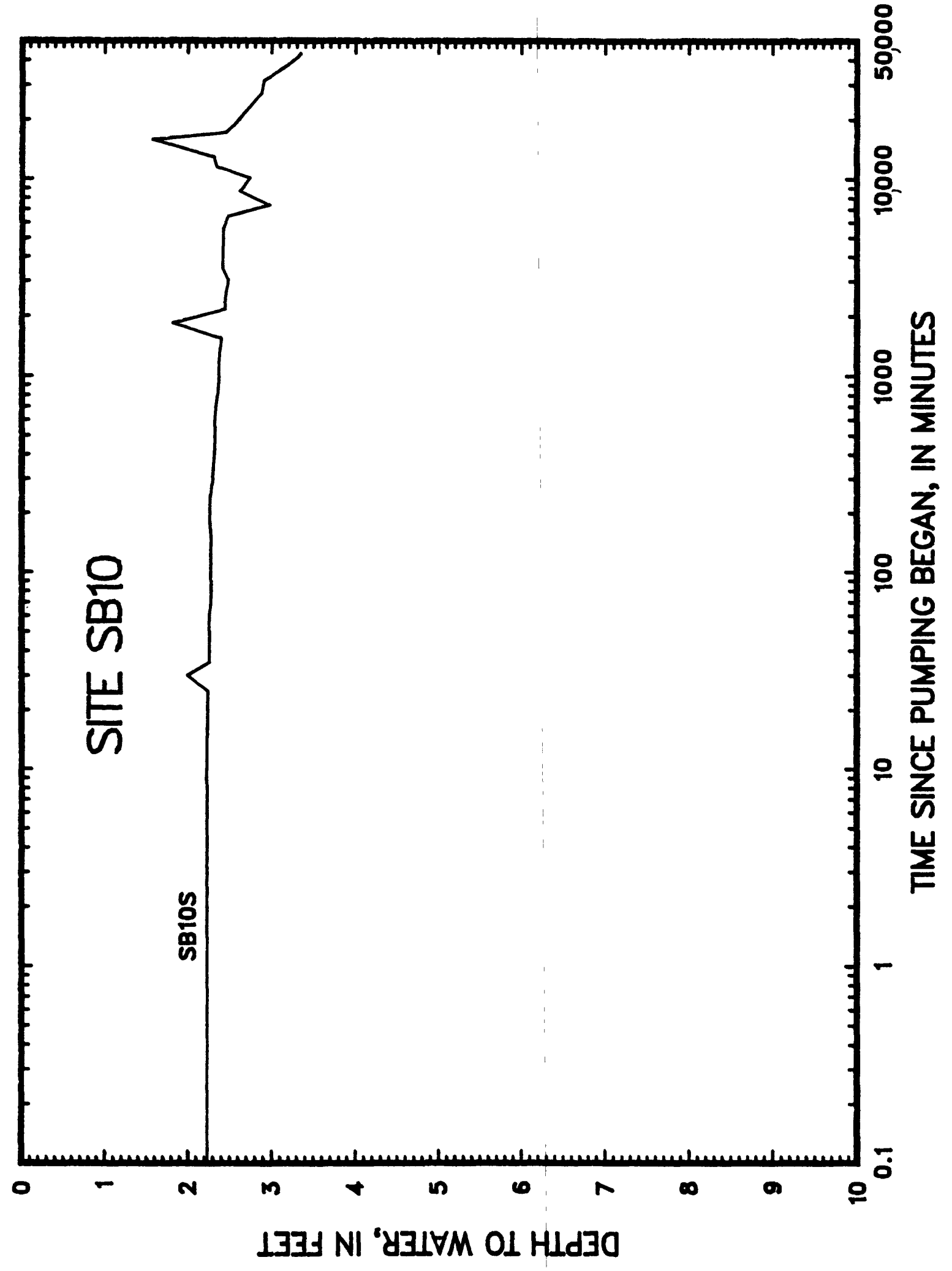

B-44 


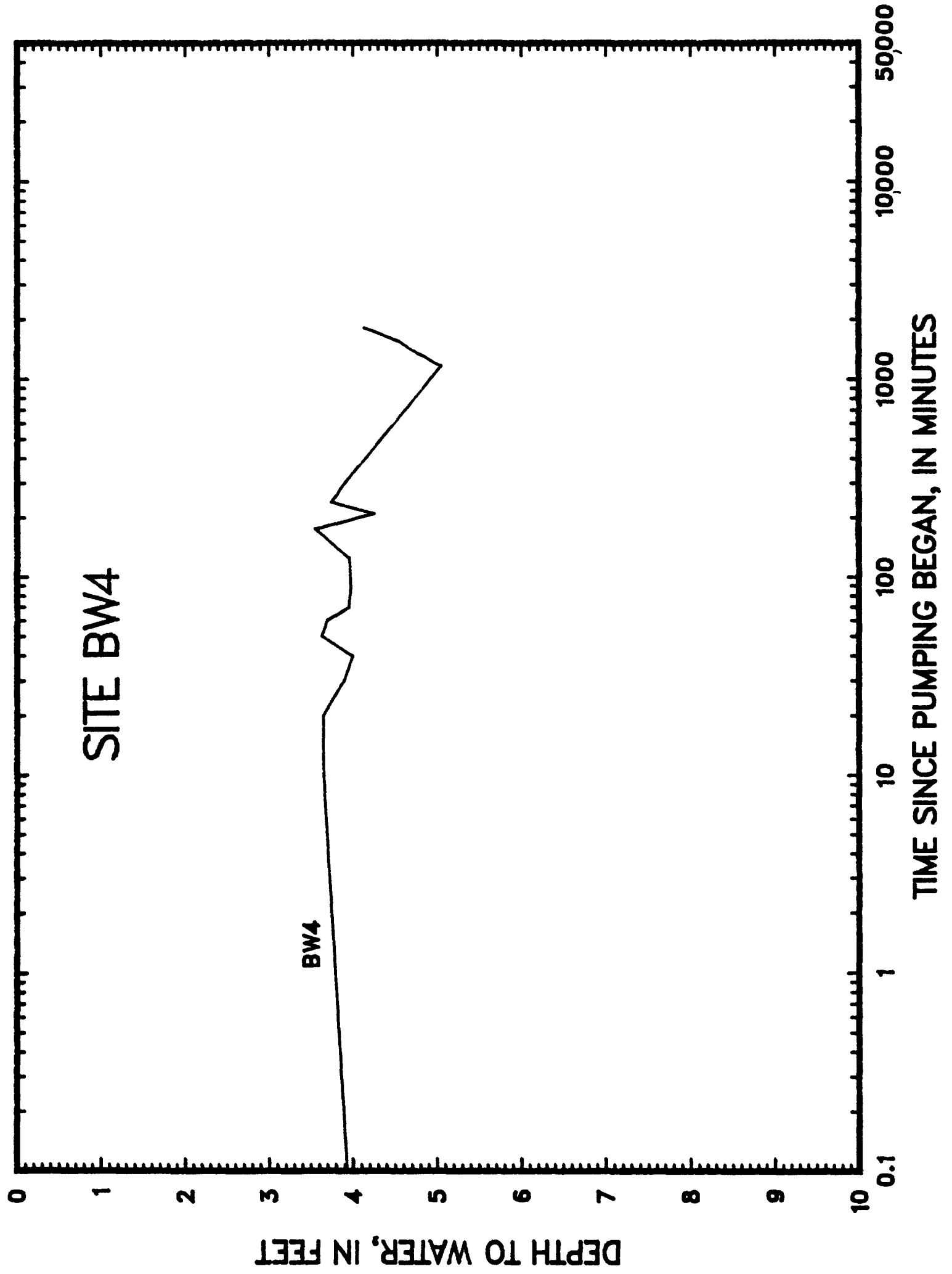

B- 45 


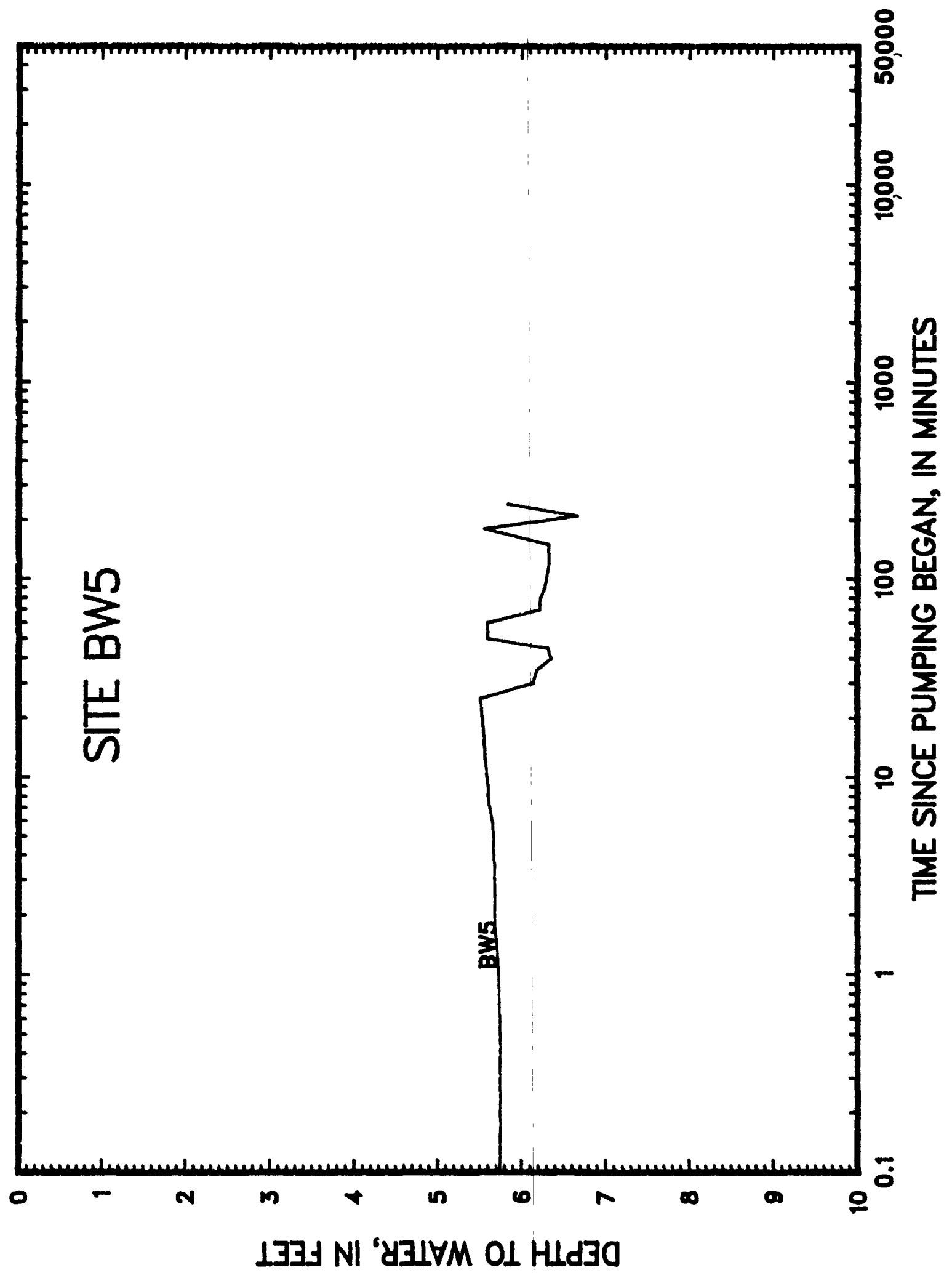




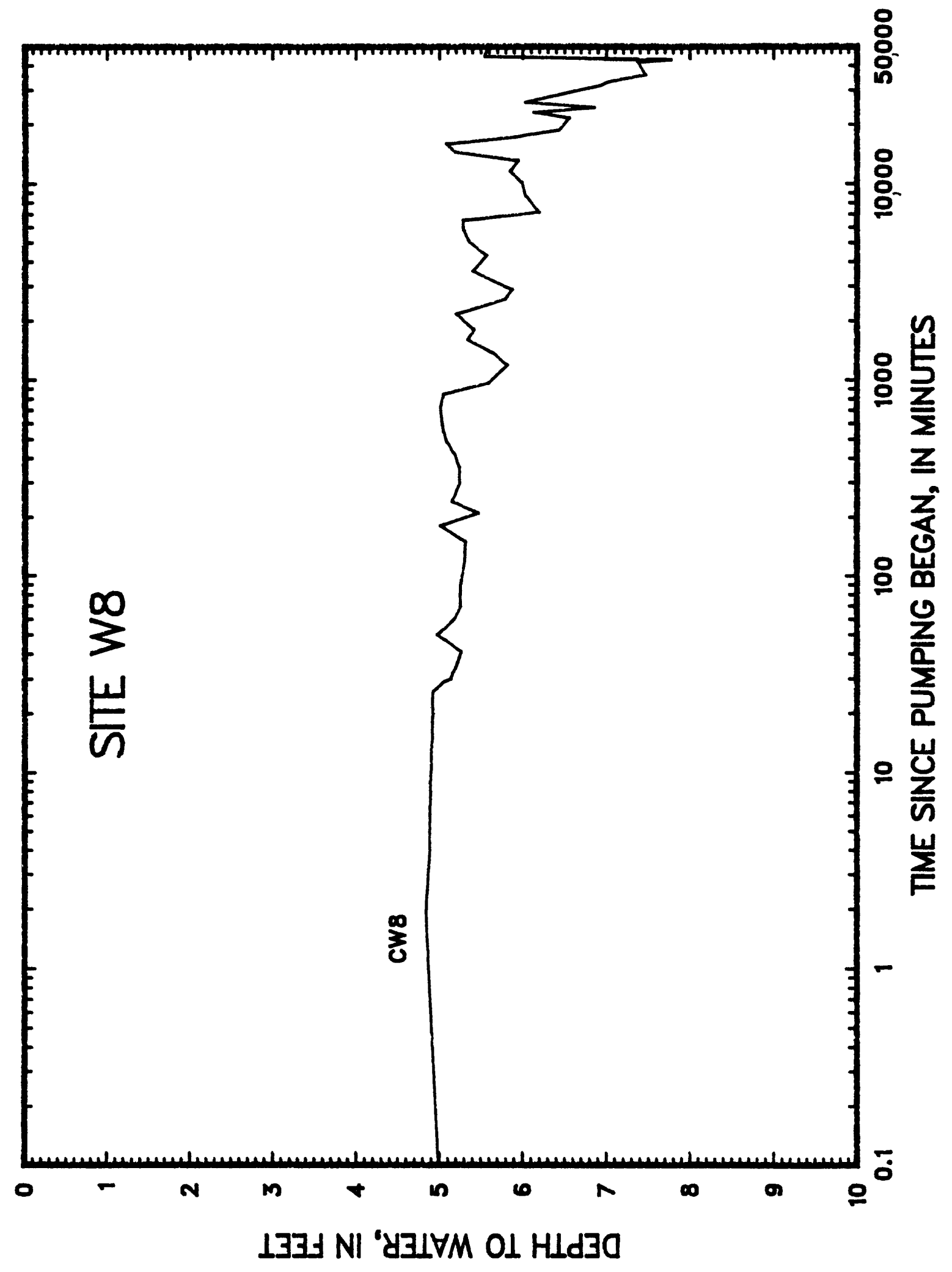




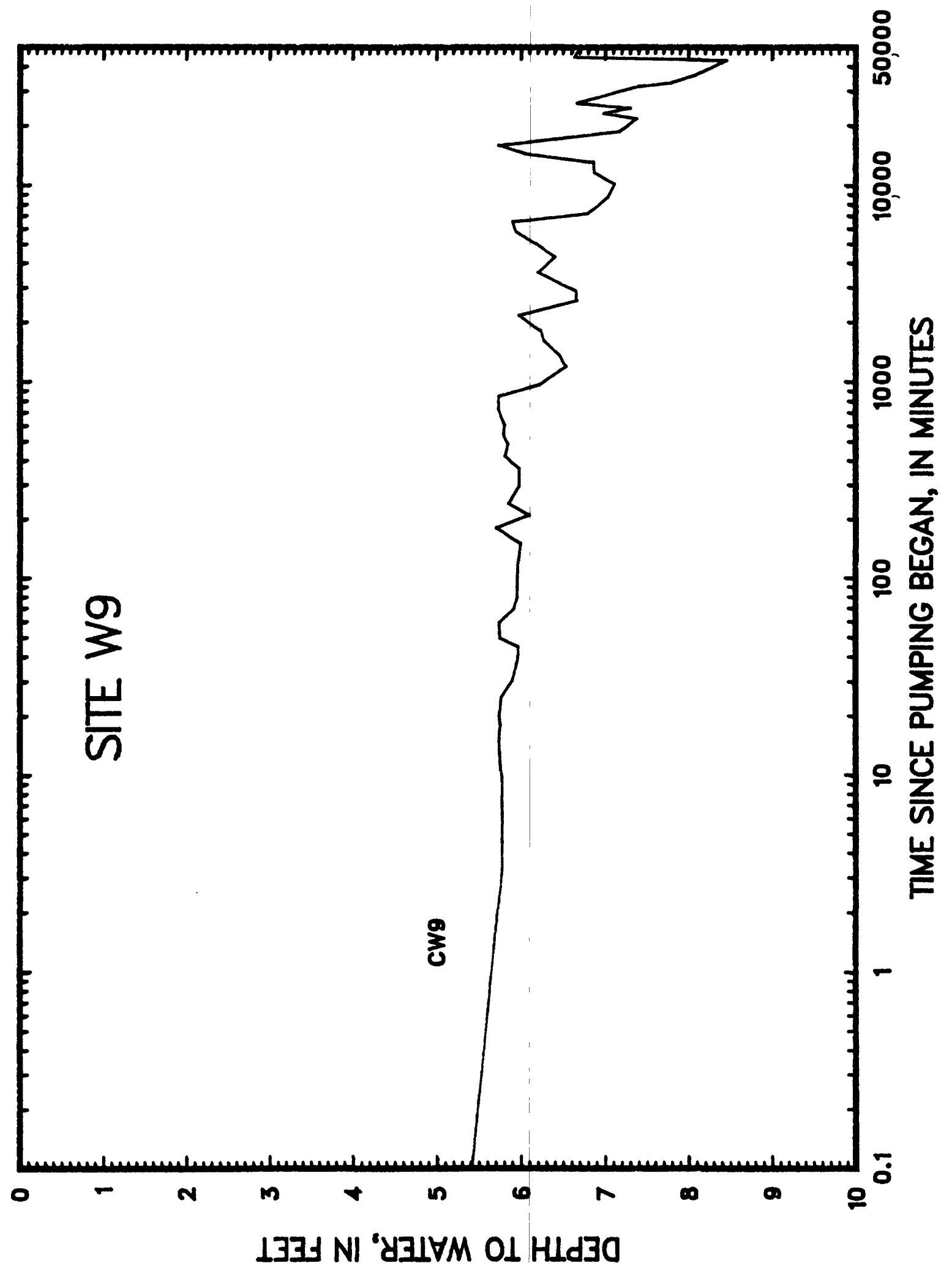




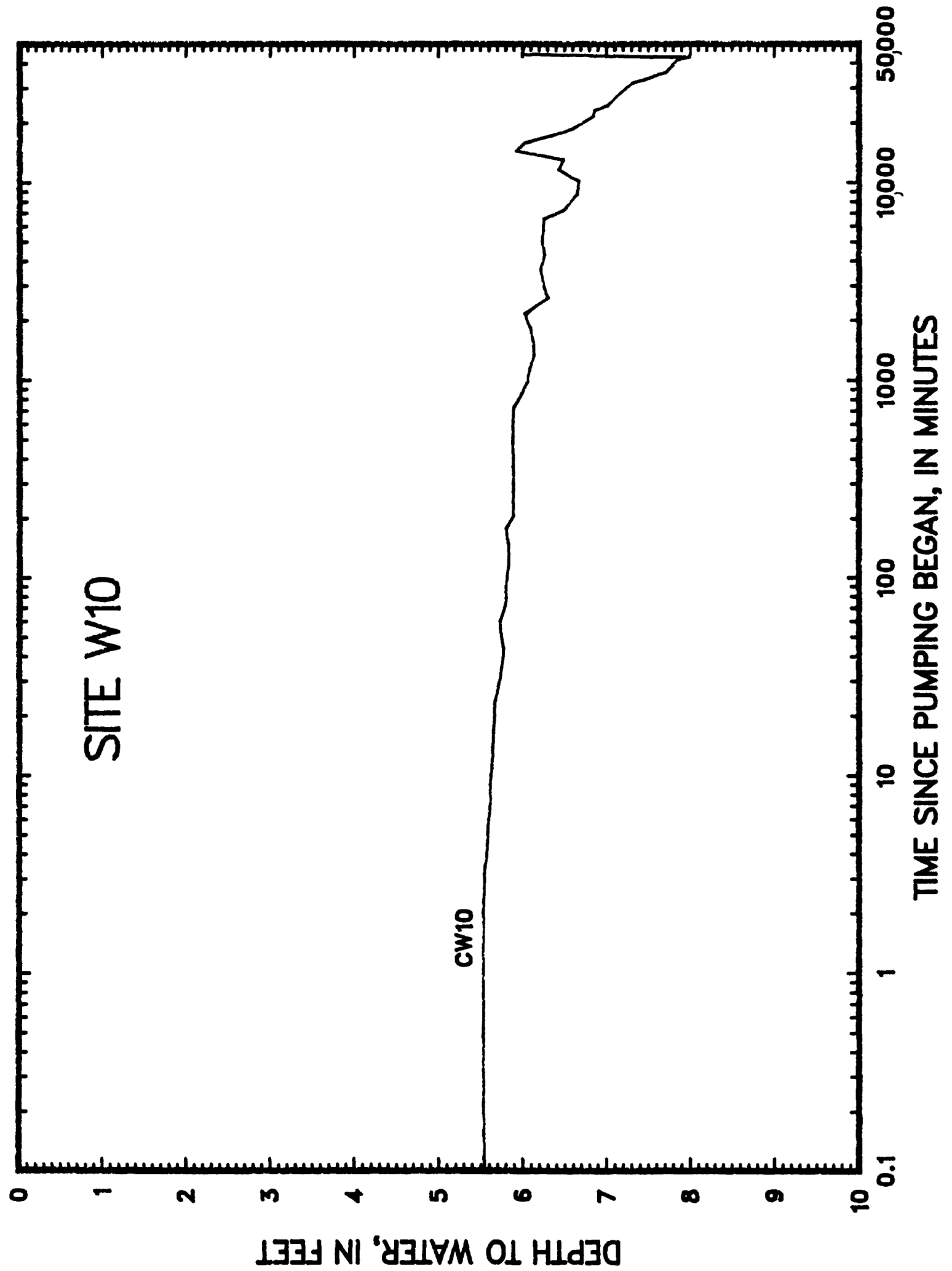




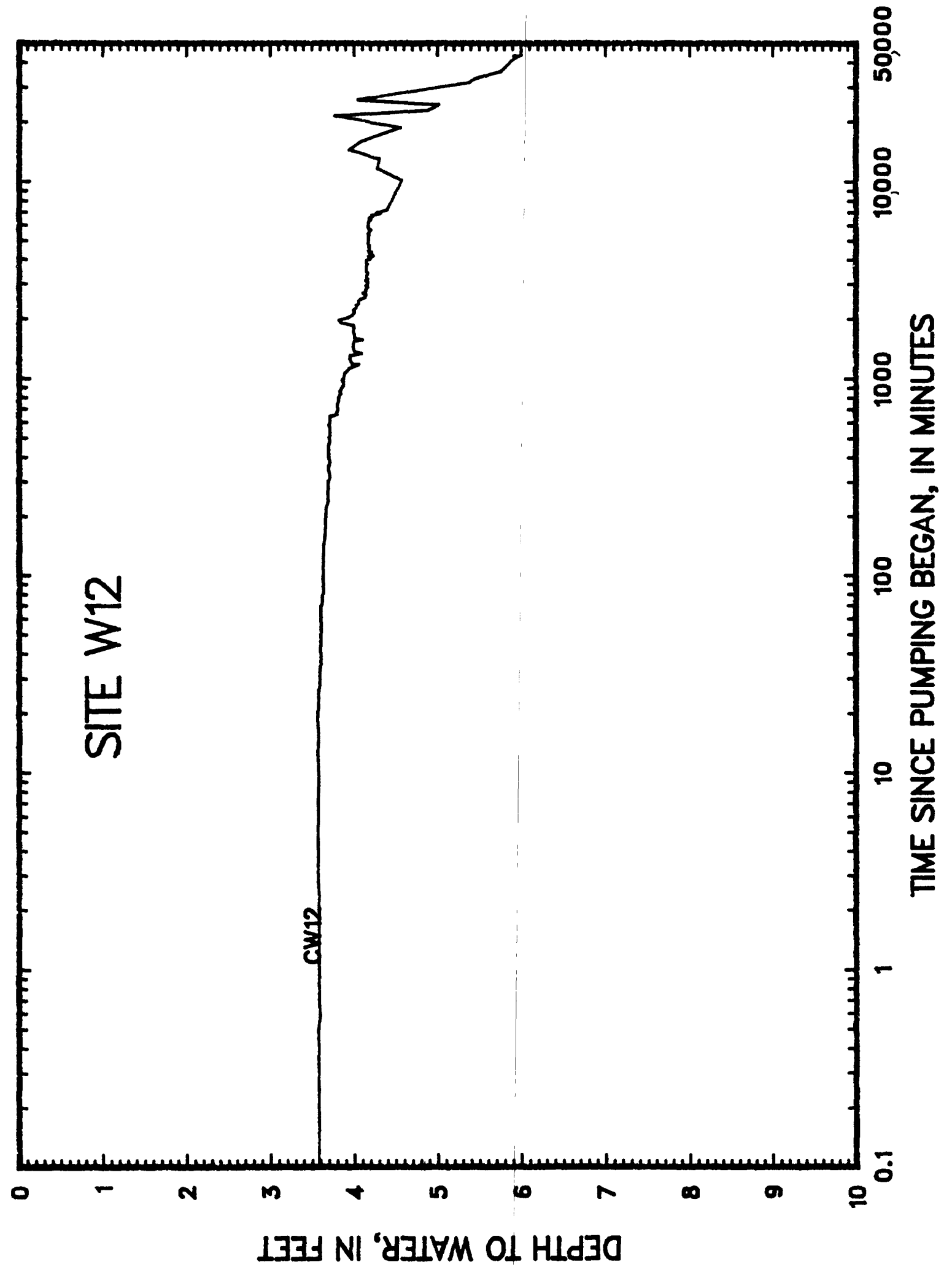

B-50 


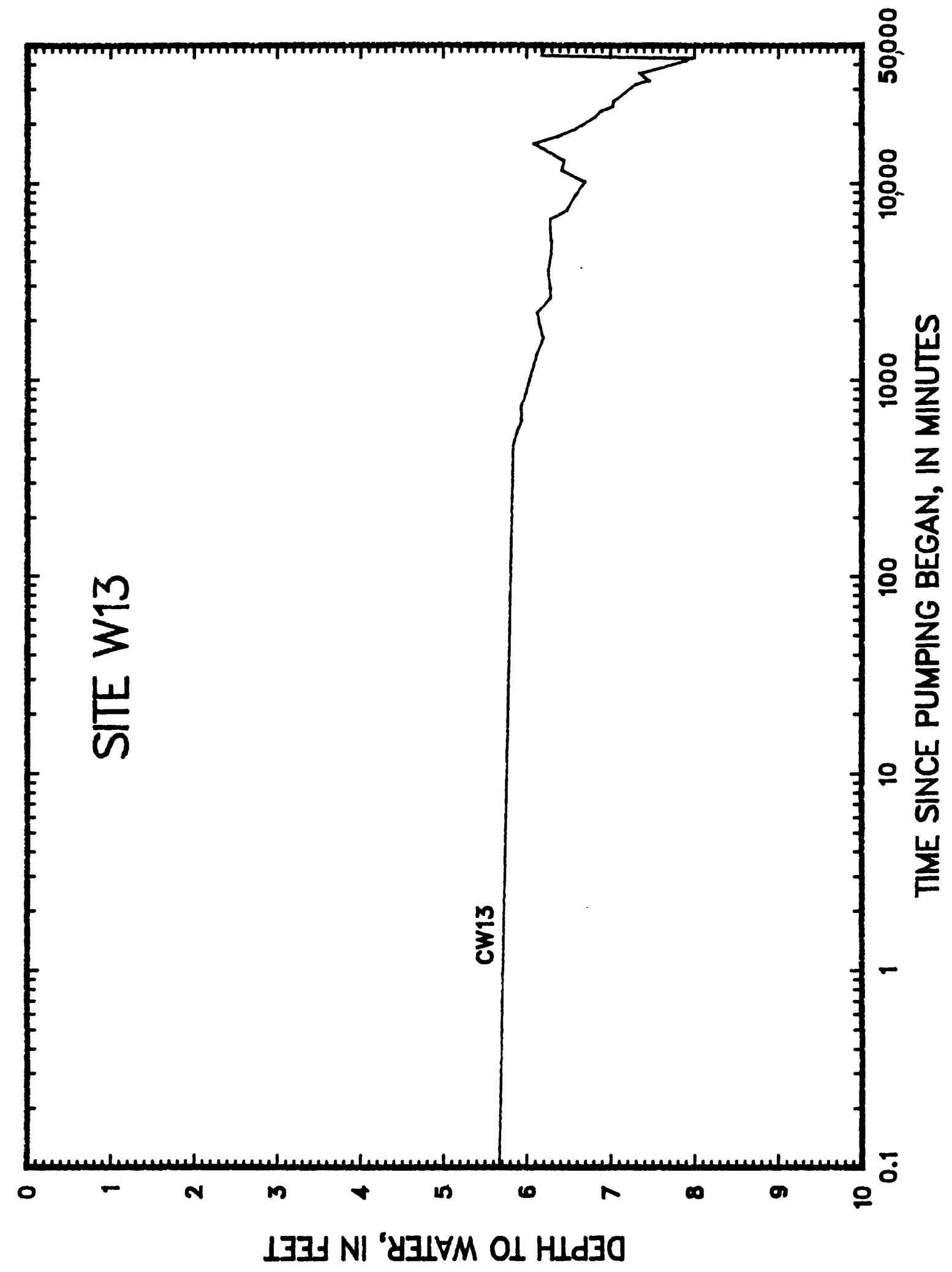




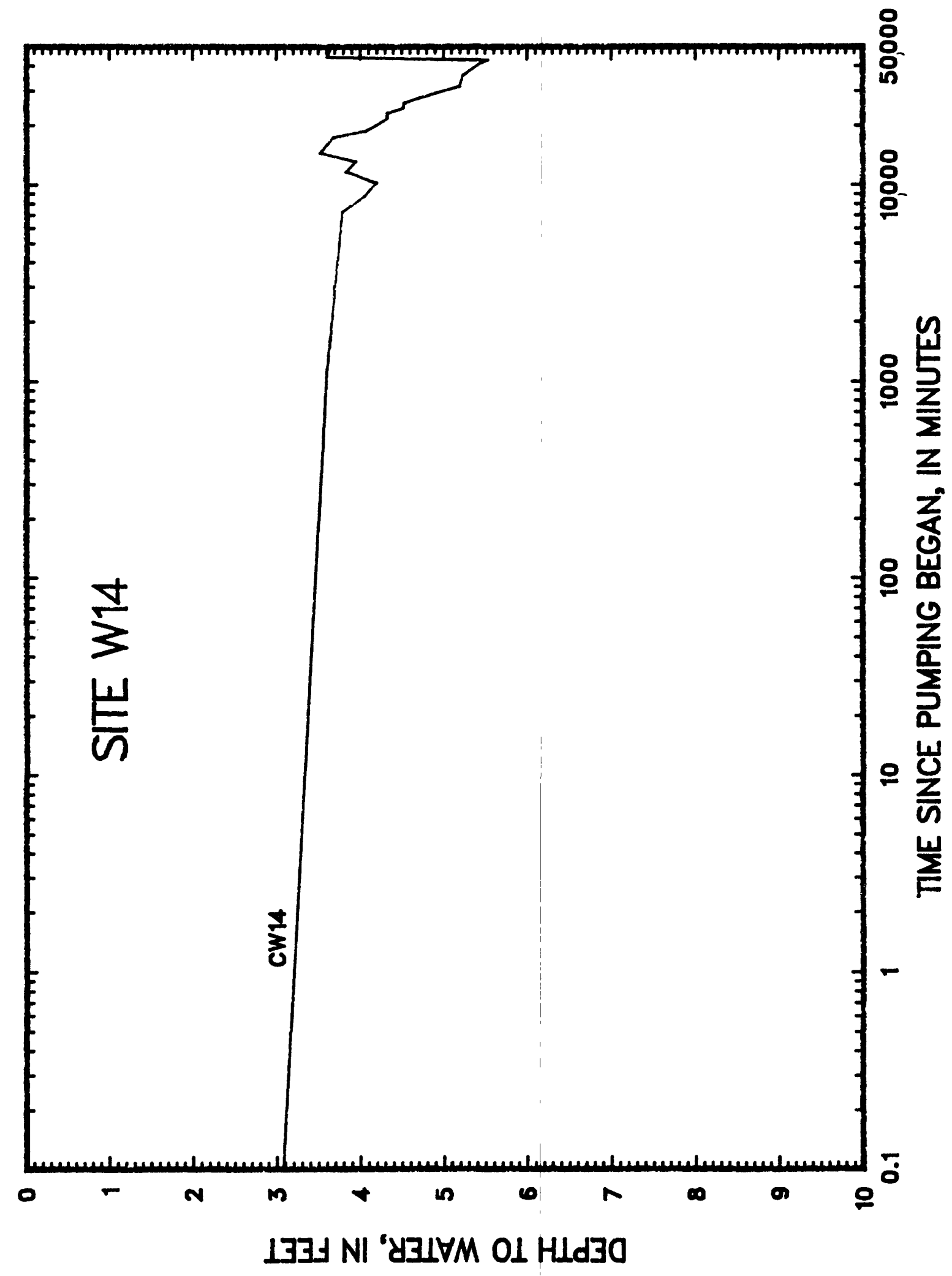

B-52 


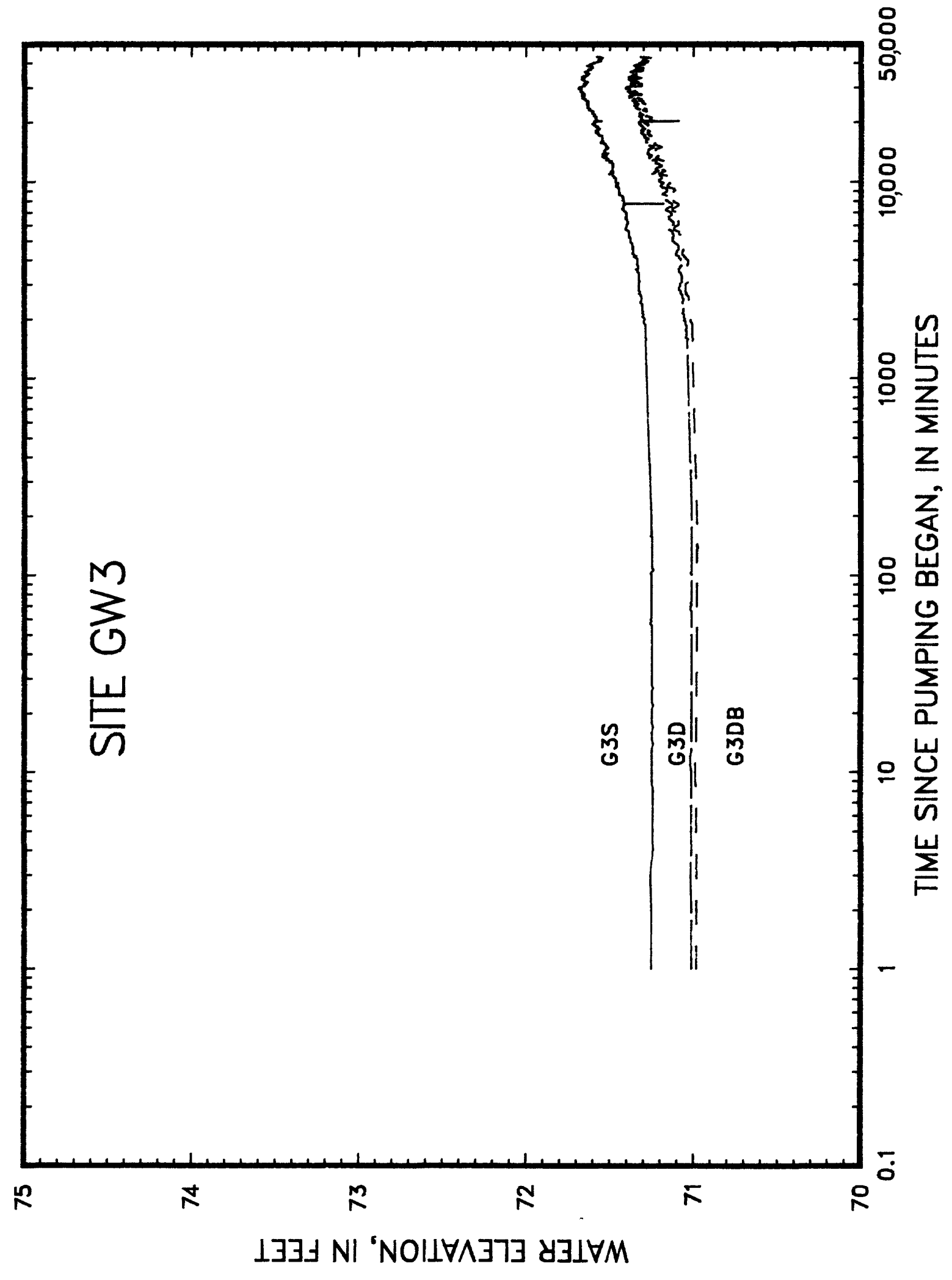




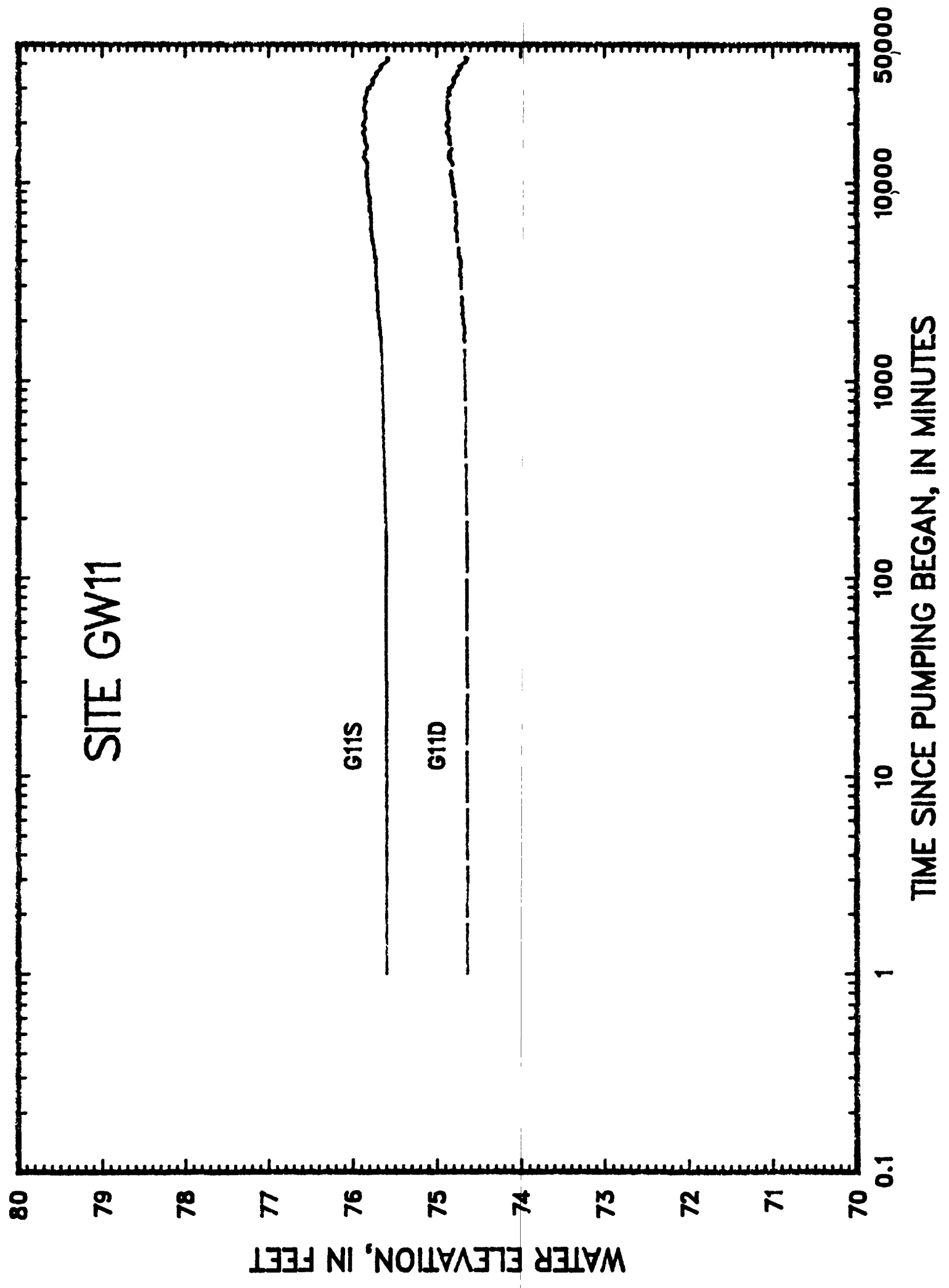




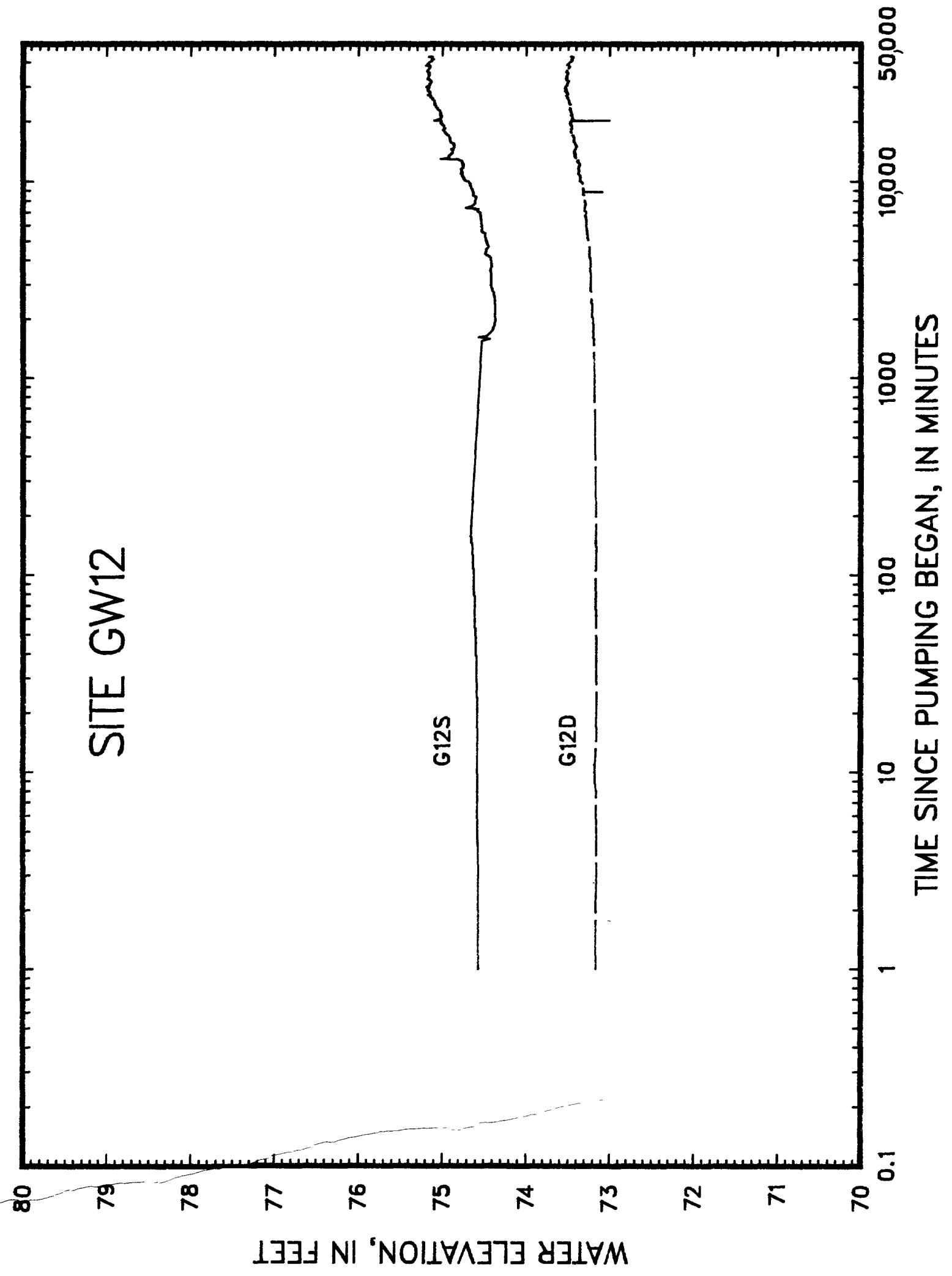




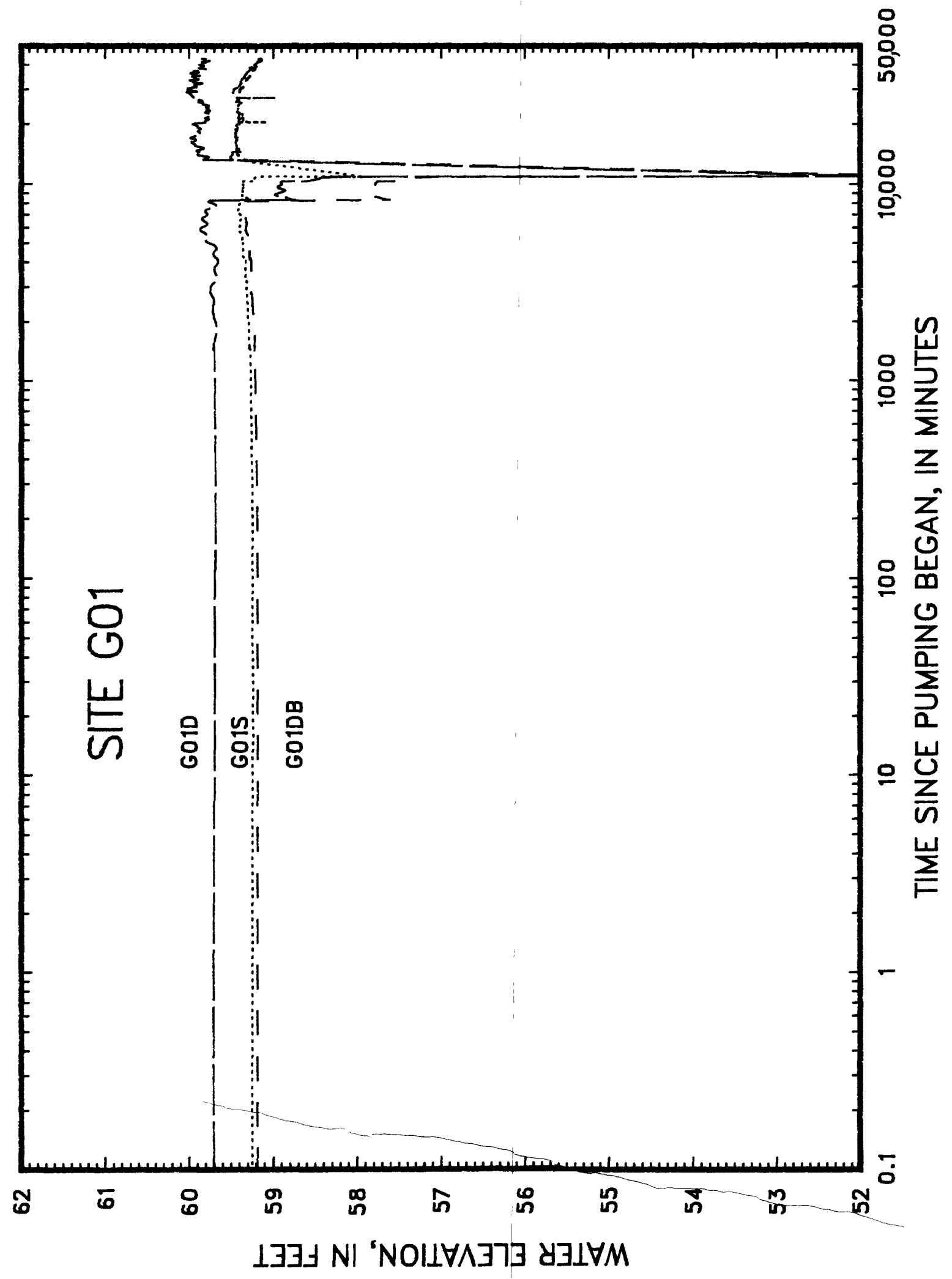




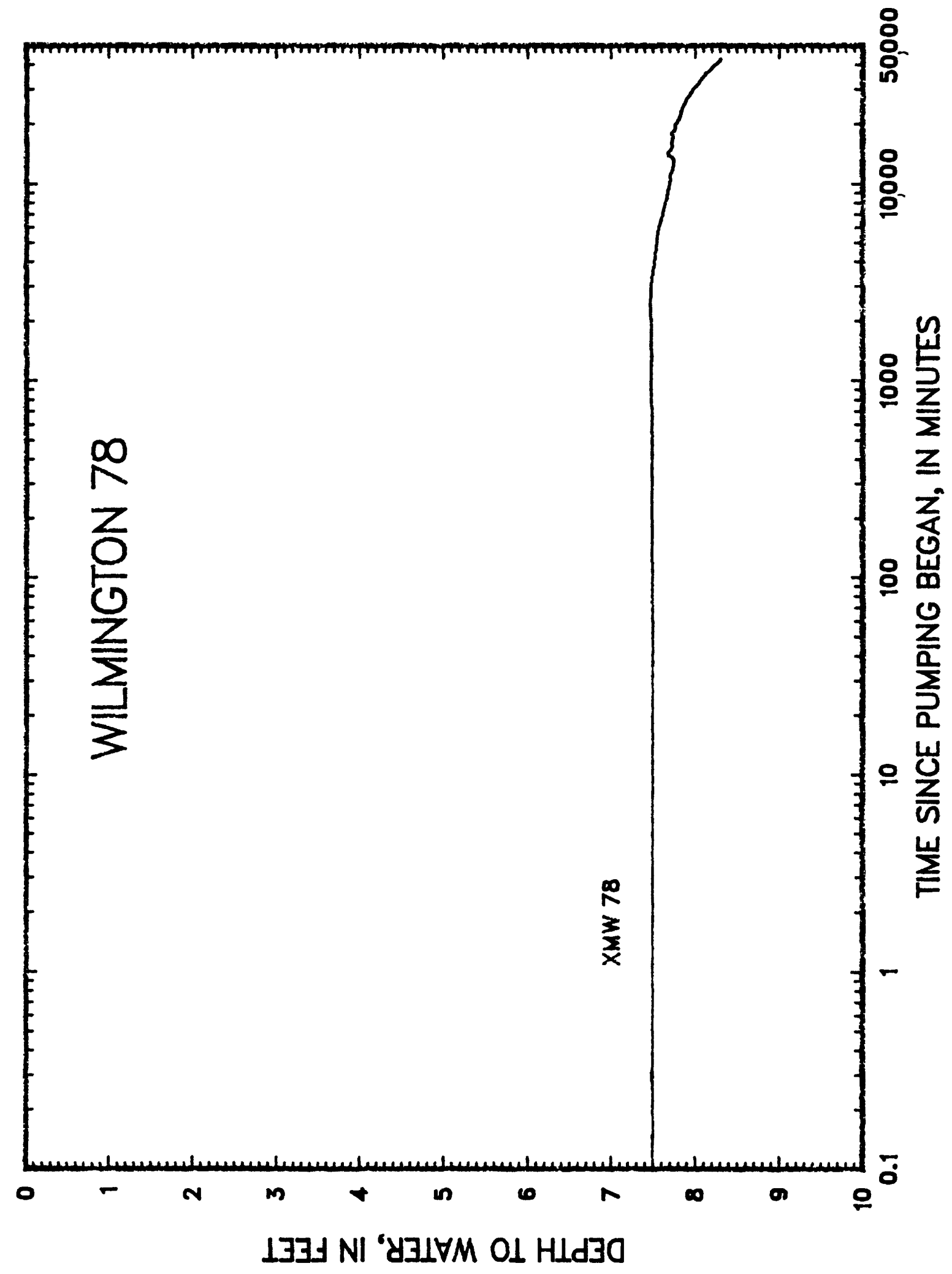

B-57 
APPENDIX C

Glossary of technical terms

C-1 
Active model area: That part of the area simulated by a computer model for which equations describing ground-water flow are solved. In this report, it is the area representing the aquifer.

Aquifer: A porous geologic material (for example, sand or gravel) that will yield water in significant quantity to a well or spring.

Aquifer test: A test to determine the water-yielding capacity of an aquifer. The test involves withdrawing a measured quantity of water from a well and measuring the resulting changes in water level in observation wells surrounding the pumping well. Potential yield of the well is estimated by analysis of the distance, time, and drawdown data.

Bedrock: Solid rock, locally called "ledge," that forms the earth's crust. It is locally exposed at the surface as an "outcrop" but more commonly is buried beneath unconsolidated deposits which range in thickness from a few inches to hundreds of feet.

Computer simulation model: A computer program to solve a set of equations which simulate a given system. In this study, the equations simulate the ground-water-flow system.

Cone of depression: The area of lowered water level around a pumping well caused by withdrawal of water from the well.

Contour line: A line on a map connecting points of equal value. A water-table contour line connects points of equal water-table altitude.

Cubic feet per second $\left(\mathrm{ft}^{3} / \mathrm{s}\right)$ : A unit of flow or discharge. For example, $1 \mathrm{ft}^{3} / \mathrm{s}$ is equal to the flow of a stream 1 foot wide and 1 foot deep flowing at an average velocity of 1 foot per second.

Discharge: The rate of flow of water at a given moment in time. In this report, discharge is expressed in cubic feet per second. See also ground-water discharge and stream discharge.

Drainage basin: The area that gathers water originating as precipitation and contributes it ultimately to a particular stream channel or lake.

Drawdown: The amount the water level is lowered either in a well or in the aquifer because of withdrawal of water by a well.

Drift: Loose rock material transported by a glacier and deposited either directly by ice or by running water emanating from the ice.

Dug well: A shallow, large-diameter well dug in the surficial sediments.
Evapotranspiration: The loss of water to the atmosphere by evaporation from water surfaces and moist soil, and by transpiration from plants.

Gage or gaging station: A site on a stream instrumented to measure the changing height of the water surface.

Gravel-packed well: A large-diameter (1-2 foot) well with gravel surrounding the well screen. The gravel increases the effective diameter of the well screen and allows water to flow into the well more easily.

Ground water: Water when it is beneath the land surface. If the water moves to the land surface, it is then called surface water.

Ground-water discharge: Water that is released from the saturated zone of the ground. It includes leakage of water into stream channels, lakes, and oceans; evapotranspiration; and withdrawal from wells.

Ground-water-flow model: A computer program to solve a set of equations that simulate groundwater flow.

Homogeneous: Uniform in composition.

Hydraulic conductivity: The capacity of a cube of porous material to transmit water; expressed in a volume per area per day $\left(\mathrm{ft}^{3} / \mathrm{ft}^{2}\right) / \mathrm{d}$ or $\mathrm{ft} / \mathrm{d})$. A material has a hydraulic conductivity of $1 \mathrm{ft} / \mathrm{d}$ if, in 1 day, it transmits 1 cubic foot of water through a 1-square-foot cross-section measured at right angles to the direction of flow, where there is a 1-foot change in water level over a 1-foot flow path.

Hydraulic connection: A stream and aquifer are hydraulically connected if fluctuations in flow or water level in one can affect the flow or water level in the other.

Hydrologic boundary: A physical feature that controls the flow of water through the ground. A hydraulic boundary limits or defines an aquifer.

Induced infiltration: Recharge to the ground water from a surface-water body due to the pumping of a nearby well and the resultant lowering of the ground-water level below the surfacewater level.

Intermittent stream: A stream that is dry during part of the year.

Leaky boundary: Edge of a hydrologic system or model which allows water to either enter or leave the system. 
Model: Physical, analytical, or mathematical representation of a natural system.

Model boundary: Boundary of the active model area in which ground-water flow is computed. Model boundaries generally coincide with hydrologic boundaries.

Node: In this report, the center point of a rectangular block of a computer-simulation model. Often used to refer to the entire block.

Observation well: A nonpumping well that is used to measure the depth to the water table.

Outcrop: Exposure of bedrock at the land surface.

Perennial stream: A stream that flows continuously throughout the year.

Permeable: Material is permeable if it has pores or openings that permit liquids to pass through.

Piezometer: An observation well constructed with a relatively short screen used to measure hydraulic head below the water table.

Pore space: Open spaces between the grains in a sediment.

Pumpage: Volume of water pumped from a well.

Recharge: Water that is added to the ground water in the saturated zone.

Saturated thickness: Thickness of the saturated part of an aquifer. In the Aberjona River valley, the difference in altitude between the water table and the bedrock surface.

Saturated zone: A subsurface zone in which all open spaces are filled with water. The water table is the upper limit of this zone.

Seepage run: A series of streamflow measurements along the length of a stream after a period of no precipitation when all the streamflow is assumed to be ground-water discharge. Gains and losses in flow along individual stream reaches are determined from comparison of the measurements.

Seismic refraction: A geophysical method of determining the depth to the water table or to bedrock. A seismograph is used to determine the time it takes sound energy created by a small explosion to reach a series of sensors. Because sound travels at different velocities in different rock materials and is refracted (bent) at the boundary between these materials, it is possible to determine depths to different types of material.
Steady state: Average, natural, unchanging conditions.

Stratified drift: A sorted and layered sediment deposited by meltwater from a glacier; may include separate layers of sand, gravel, silt, and clay.

Stream-aquifer system: An aquifer and a stream that are hydraulically connected.

Streamflow measurement: The measurement of streamflow. Units of flow are cubic feet per second. Also referred to as discharge measurement.

Surface runoff: Water that moves over the land surface directly to streams or lakes. Surface runoff usually occurs shortly after rainfall or snowmelt.

Surface water: Water when it is on the surface of the land in lakes and rivers. If it seeps into the ground, it is called ground water.

Surficial sediments (deposits): Unconsolidated deposits lying on top of bedrock.

Till: An unsorted, unstratified sediment deposited directly by a glacier. Till may be composed of boulders, gravel, sand, silt, and clay.

Transpiration: The release of water vapor to the atmosphere by plants.

Unconsolidated: Loose, not firmly cemented or interlocked; for example, sand in contrast to sandstone.

Volatile organic compound: Chemical which vaporizes when exposed to air. Many highly toxic solvents are volatile organic compounds.

Water table: The upper surface of the saturated zone. The altitude of the water table is indicated by the altitude of the water level in an observation well that penetrates to the bottom of the aquifer and allows water to enter the well at any level.

Well capacity: Highest rate at which water can be withdrawn from a particular well.

Well field: A group of small-diameter (usually 2.5inch) wells connected to a single pump.

Well screen: Slotted section of a well, usually at the bottom, through which water can enter the well. 